\title{
\#USGS
}

science for a changing world

Prepared in cooperation with the Alabama Department of Economic and Community Affairs, Office of Water Resources

\section{Water Use, Availability, and Net Demand in the Tennessee River Watershed within Alabama, 2005}

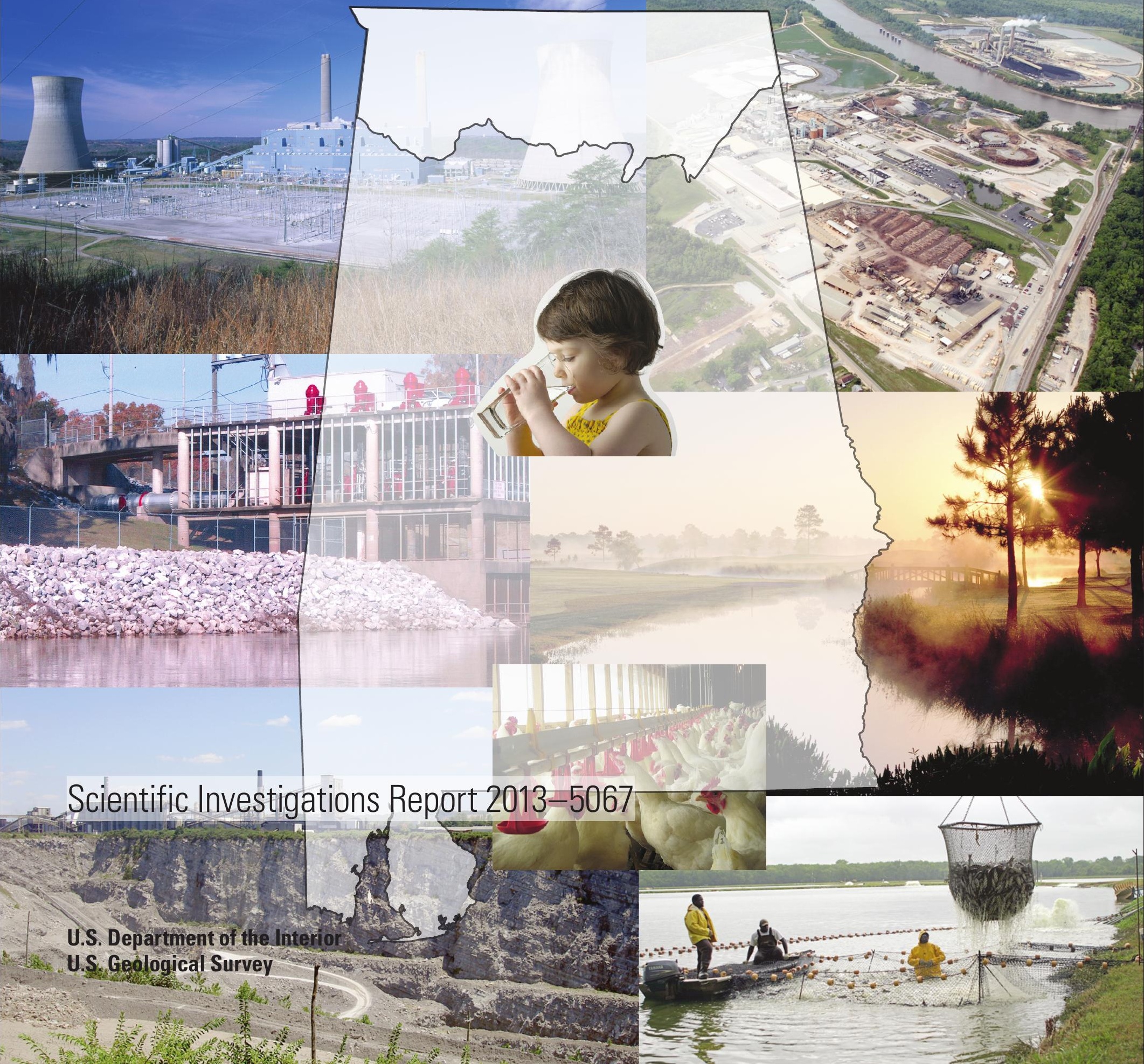


Public suppliers and private wells provide plentiful

water to the residents and visitors of Alabama. (Photo courtesy of Glenn Phillips.)

The coal-fired James $\mathrm{H}$. Miller Steam Plant employs a recirculating-induced draft tower to cool water before release as return flow to the Mulberry Fork of the Black Warrior River. (Photo courtesy of Sheila A. Garrett, Alabama Power Company.)

A surface-water intake on the Tallapoosa River is one of several sources of water for

the City of Montgomery, Alabama. (Photo courtesy of Montgomery Water Works and Sanitary Sewer Board.

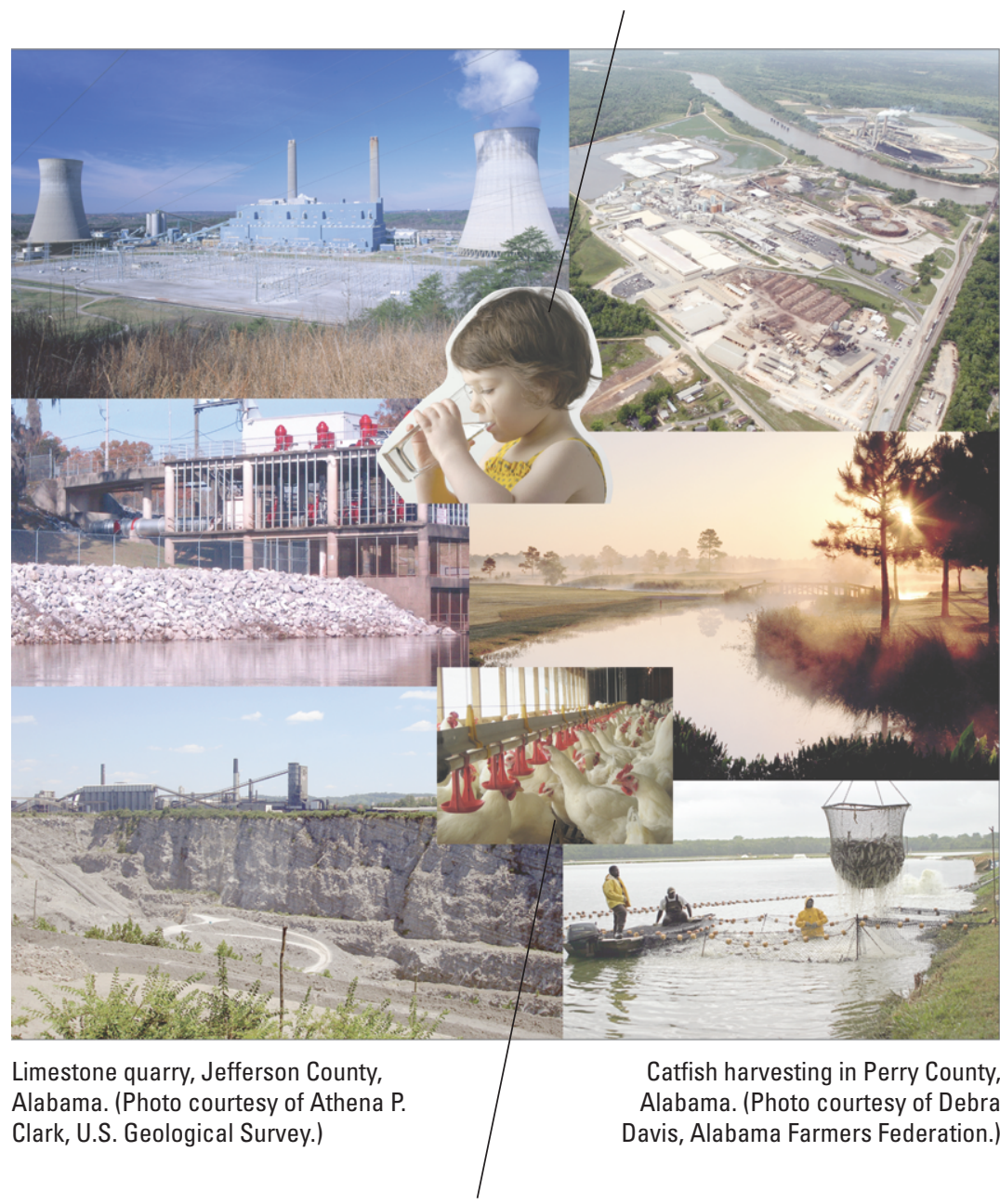

Breeder chickens in Cleburne County, Alabama. (Photo by Michael J. Harper, Alabama Office of Water Resources.)
Boise Paper Mill in Jackson, Alabama. (Photo courtesy of Boise Papers.)

Golf course ponds collect rainfall and runoff. Shown is Craft Farms Golf Resort, Cypress Bend Golf Course, Foley, Alabama. (Photo courtesy of Alabama Bureau of Tourism \& Travel.) 


\section{Water Use, Availability, and Net Demand in the Tennessee River Watershed within Alabama, 2005}

By Amy C. Gill, Michael J. Harper, and Thomas M. Littlepage

Prepared in cooperation with the Alabama Department of Economic and Community Affairs, Office of Water Resources

Scientific Investigations Report 2013-5067 


\title{
U.S. Department of the Interior SALLY JEWELL, Secretary
}

\section{U.S. Geological Survey Suzette M. Kimball, Acting Director}

\author{
U.S. Geological Survey, Reston, Virginia: 2013
}

For more information on the USGS - the Federal source for science about the Earth, its natural and living resources, natural hazards, and the environment, visit http://www.usgs.gov or call 1-888-ASK-USGS.

For an overview of USGS information products, including maps, imagery, and publications, visit http://www.usgs.gov/pubprod

To order this and other USGS information products, visit http://store.usgs.gov

Any use of trade, firm, or product names is for descriptive purposes only and does not imply endorsement by the U.S. Government.

Although this information product, for the most part, is in the public domain, it also may contain copyrighted materials as noted in the text. Permission to reproduce copyrighted items must be secured from the copyright owner.

Suggested citation:

Gill, A.C., Harper, M.J., and Littlepage, T.M., 2013, Water use, availability, and net demand in the Tennessee River watershed within Alabama, 2005: U.S. Geological Survey Scientific Investigations Report 2013-5067, 42 p. 


\section{Contents}

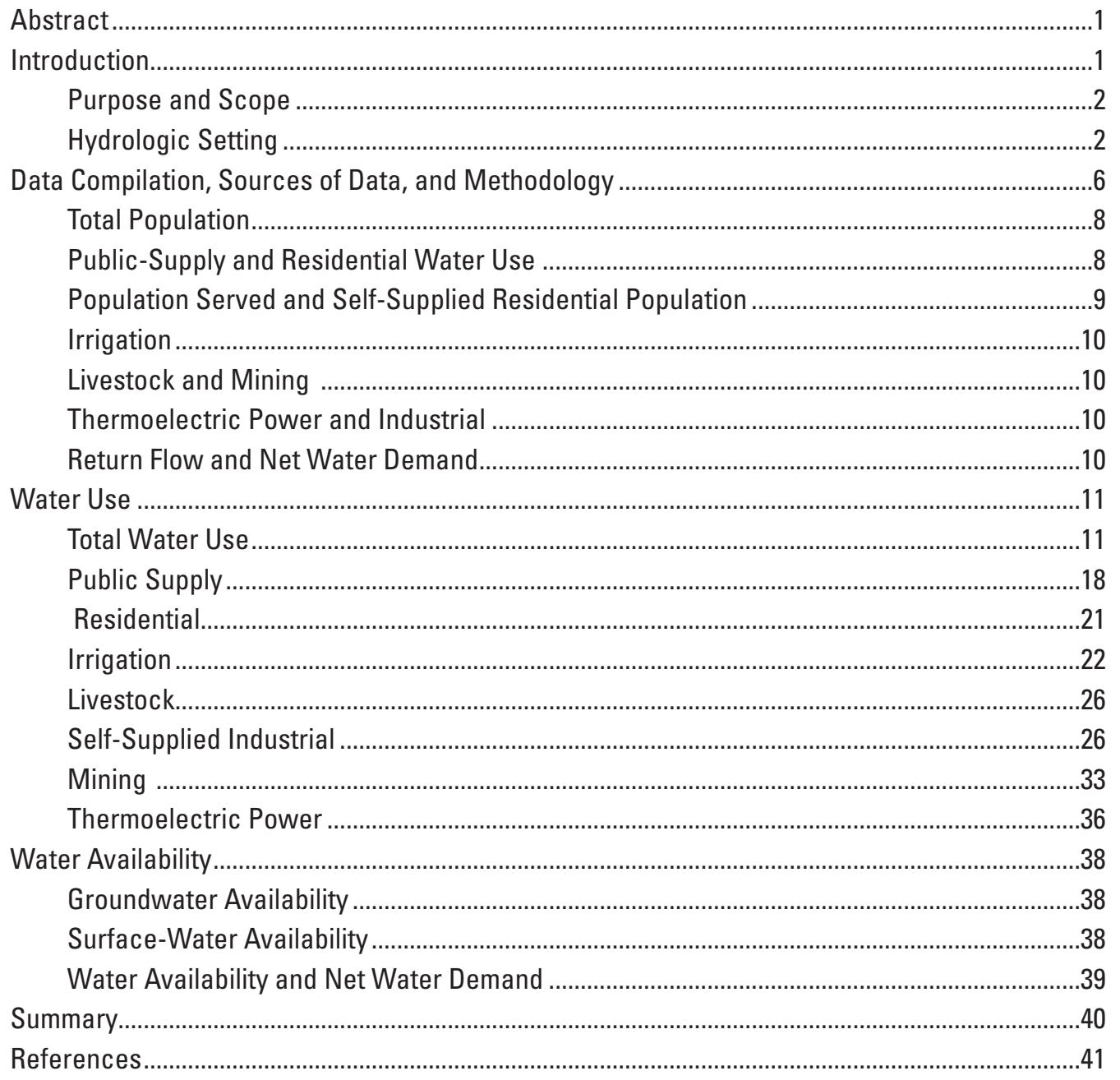

\section{Figures}

1. Map showing hydrologic subregions, rivers, state capital, and study area cities

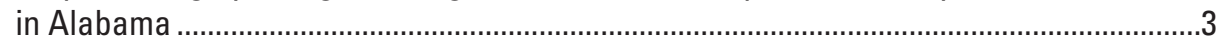

2. Map showing Alabama counties in and partially in the Tennessee River watershed......4

3. Map showing subregions and subbasins of the Tennessee River watershed within

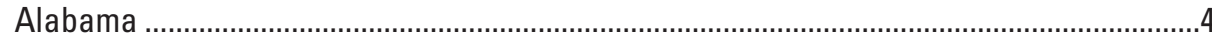

4. Map showing location of major dams in the Tennessee River watershed in

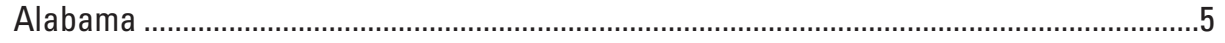

5. Map showing principal aquifers in the Tennessee River watershed in Alabama .............5

6. Graph showing comparison of freshwater withdrawals by category of use in the Tennessee River watershed within Alabama, 2005 .....................................................11

7. Graph showing sources of water used in the Tennessee River watershed in Alabama, 2005 
8. Maps showing total freshwater withdrawals by source and county in the Tennessee River watershed in Alabama, 2005.

9. Maps showing total freshwater withdrawals by source and hydrologic subbasin in the Tennessee River watershed in Alabama, 2005.

10. Graph showing source of public-supply water withdrawals in the Tennessee River watershed in Alabama, 2005.

11. Map showing public-supply freshwater withdrawals by source and county in the Tennessee River watershed in Alabama, 2005

12. Map showing public-supply freshwater withdrawals by source and subbasin in the Tennessee River watershed in Alabama, 2005.

13. Maps showing self-supplied residential groundwater withdrawals by county in the Tennessee River watershed in Alabama, 2005.

14. Maps showing Self-supplied residential population as a percentage of total population and self-supplied residential population by county in the Tennessee River watershed in Alabama, 2005.

15. Graphs showing source of water for irrigation use in the Tennessee River Watershed in Alabama, 2005

16. Maps showing irrigation withdrawals by source and county in the Tennessee River watershed in Alabama, 2005...

17. Maps showing irrigation withdrawals by source and subbasin in the Tennessee River watershed in Alabama, 2005...

18. Graph showing source of water for livestock use in the Tennessee River watershed in Alabama, 2005

19. Maps showing withdrawals for livestock by source and county in the Tennessee River watershed in Alabama, 2005.

20. Maps showing withdrawals for livestock by source and subbasin in the Tennessee River watershed in Alabama, 2005.

21. Graph showing source of water for self-supplied industrial use in the Tennessee River watershed in Alabama, 2005.

22. Maps showing self-supplied industrial freshwater withdrawals by source and county in the Tennessee River watershed in Alabama, 2005

23. Maps showings self-supplied industrial freshwater withdrawals by source and subbasin in the Tennessee River watershed in Alabama, 2005 31

24. Graph showing distribution of total industrial withdrawals by Standard Industrial Classification grouping in the Tennessee River watershed within Alabama, 2005 .........32

25. Graph showing source of water for mining use in the Tennessee River watershed in Alabama, 2005 .

26. Maps showing mining freshwater withdrawals by source and county in the Tennessee River watershed in Alabama, 2005

27. Map showing mining withdrawals by source and subbasin in the Tennessee River watershed in Alabama, 2005.

28. Map showing thermoelectric-power freshwater withdrawals (all surface water) by county in the Tennessee River watershed in Alabama, 2005.

29. Map showing thermoelectric-power freshwater withdrawals (all surface water) by subbasin in the Tennessee River watershed in Alabama, 2005. .37

30. Geology and geologic areas within the Tennessee River watershed in Alabama ..........39 


\section{Tables}

1. Hydrologic unit codes and names, Tennessee River watershed within Alabama ...........6

2. Summary of data sources by water-use category and type of data for the Tennessee River watershed within Alabama .......................................................................7

3. Total freshwater withdrawals and consumption by source and county in the Tennessee River watershed within Alabama, 2005

4. Total freshwater withdrawals and consumption by source and by hydrologic subregion and subbasin in the Tennessee River watershed within Alabama, 2005 .......12

5. Total freshwater withdrawals by category of use and county in the Tennessee River watershed within Alabama, 2005..

6. Total freshwater withdrawals by category of use and hydrologic subregion and subbasin in the Tennessee River watershed within Alabama, 2005

7. Total surface-water withdrawals by category of use and county in the Tennessee River watershed within Alabama, 2005...

8. Total surface-water withdrawals by category of use and hydrologic subregion and subbasin in the Tennessee River watershed within Alabama, 2005

9. Total groundwater withdrawals by category of use and county in the Tennessee River watershed within Alabama, 2005.

10. Total groundwater withdrawals by category of use and hydrologic subregion and subbasin in the Tennessee River watershed within Alabama, 2005.

11. Public-supply population served, withdrawals, per capita use, return flows, and consumption by county in the Tennessee River watershed in Alabama, 2005

12. Public-supply water use by hydrologic subregion and subbasin in the Tennessee River watershed within Alabama, 2005

13. Residential water users, water use, and per capita use by county in the Tennessee River watershed within Alabama, 2005

14. Irrigation water use by county in the Tennessee River watershed in Alabama, 2005 ....23

15. Irrigation water use by hydrologic subregion and subbasin in the Tennessee River watershed within Alabama, 2005

16. Water withdrawals for livestock by county in the Tennessee River watershed within Alabama, 2005.

17. Water withdrawals for livestock by hydrologic subregion and subbasin in Tennessee River watershed within Alabama, 2005

18. Self-supplied industrial water withdrawals, returns, and net demand by county in the Tennessee River watershed within Alabama, 2005.

19. Self-supplied industrial water withdrawals, returns, and net demands by hydrologic subregion and subbasin in the Tennessee River watershed within Alabama, 2005 .......29

20. Self-supplied industrial water withdrawals by Standard Industrial Classification and by source in the Tennessee River watershed in Alabama, 2005

21. Mining water withdrawals, returns, and net demands by county in the Tennessee River watershed within Alabama, 2005

22. Mining water withdrawals, returns, and net demands by hydrologic subregion and subbasin in the Tennessee River watershed within Alabama, 2005.

23. Thermoelectric-power surface-water withdrawals and consumption by county in the Tennessee River watershed within Alabama, 2005.

24. Thermoelectric-power surface-water withdrawals and consumption, and power generated by hydrologic subregion and subbasin in the Tennessee River watershed within Alabama, 2005 
25. Estimated available groundwater in the Tennessee River watershed in Alabama .........38

26. Estimated available surface water in the Tennessee River watershed in Alabama.......38

Conversion Factors and Datums

\begin{tabular}{|c|c|c|}
\hline Multiply & By & To obtain \\
\hline \multicolumn{3}{|c|}{ Length } \\
\hline inch & 2.54 & centimeter $(\mathrm{cm})$ \\
\hline inch & 25.4 & millimeter (mm) \\
\hline foot $(\mathrm{ft})$ & 0.3048 & meter $(\mathrm{m})$ \\
\hline mile (mi) & 1.609 & kilometer $(\mathrm{km})$ \\
\hline \multicolumn{3}{|c|}{ Area } \\
\hline acre & 4,047 & square meter $\left(\mathrm{m}^{2}\right)$ \\
\hline square mile $\left(\mathrm{mi}^{2}\right)$ & 259.0 & hectare (ha) \\
\hline square mile $\left(\mathrm{mi}^{2}\right)$ & 2.590 & square kilometer $\left(\mathrm{km}^{2}\right)$ \\
\hline \multicolumn{3}{|c|}{ Volume } \\
\hline gallon (gal) & 3.785 & liter (L) \\
\hline gallon (gal) & 0.003785 & cubic meter $\left(\mathrm{m}^{3}\right)$ \\
\hline gallon (gal) & 3.785 & cubic decimeter $\left(\mathrm{dm}^{3}\right)$ \\
\hline million gallons (Mgal) & 3,785 & cubic meter $\left(\mathrm{m}^{3}\right)$ \\
\hline acre-foot (acre-ft) & 1,233 & cubic meter $\left(\mathrm{m}^{3}\right)$ \\
\hline \multicolumn{3}{|c|}{ Flow rate } \\
\hline acre-foot per day (acre-ft/d) & 0.01427 & cubic meter per second $\left(\mathrm{m}^{3} / \mathrm{s}\right)$ \\
\hline acre-foot per year (acre-ft/yr) & 1,233 & cubic meter per year $\left(\mathrm{m}^{3} / \mathrm{yr}\right)$ \\
\hline gallon per day (gal/d) & 0.003785 & cubic meter per day $\left(\mathrm{m}^{3} / \mathrm{d}\right)$ \\
\hline million gallons per day (Mgal/d) & 0.04381 & cubic meter per second $\left(\mathrm{m}^{3} / \mathrm{s}\right)$ \\
\hline inch per year (in/yr) & 25.4 & millimeter per year (mm/yr) \\
\hline cubic foot per second $\left(\mathrm{ft}^{3} / \mathrm{s}\right)$ & 0.02832 & cubic meter per second $\left(\mathrm{m}^{3} / \mathrm{s}\right)$ \\
\hline \multicolumn{3}{|c|}{ Energy } \\
\hline kilowatt-hour (kWh) & $3,600,000$ & joule $(\mathrm{J})$ \\
\hline \multicolumn{3}{|c|}{ Application rate } \\
\hline gallon per day per acre & 0.003785 & cubic meter per day per acre \\
\hline $\begin{array}{l}\text { gallon per day per square mile } \\
\qquad\left[(\mathrm{gal} / \mathrm{d}) / \mathrm{mi}^{2}\right]\end{array}$ & 0.001461 & $\begin{array}{l}\text { cubic meter per day per square } \\
\text { kilometer }\left[\left(\mathrm{m}^{3} / \mathrm{s}\right) / \mathrm{km}^{2}\right]\end{array}$ \\
\hline $\begin{array}{l}\text { cubic foot per second per square } \\
\text { mile }\left[\left(\mathrm{ft}^{3} / \mathrm{s}\right) / \mathrm{mi}^{2}\right]\end{array}$ & 0.01093 & $\begin{array}{l}\text { cubic meter per second per square } \\
\text { kilometer }\left[\left(\mathrm{m}^{3} / \mathrm{s}\right) / \mathrm{km}^{2}\right]\end{array}$ \\
\hline
\end{tabular}

Temperature in degrees Celsius $\left({ }^{\circ} \mathrm{C}\right)$ may be converted to degrees Fahrenheit $\left({ }^{\circ} \mathrm{F}\right)$ as follows:

${ }^{\circ} \mathrm{F}=\left(1.8 \times{ }^{\circ} \mathrm{C}\right)+32$

Temperature in degrees Fahrenheit $\left({ }^{\circ} \mathrm{F}\right)$ may be converted to degrees Celsius $\left({ }^{\circ} \mathrm{C}\right)$ as follows:

${ }^{\circ} \mathrm{C}=\left({ }^{\circ} \mathrm{F}-32\right) / 1.8$

Horizontal coordinate information is referenced to North American Datum of 1983 (NAD 83). 


\section{Acronyms and Abbreviations Used in this Report}

$\begin{array}{ll}\text { ADAI } & \text { Alabama Department of Agriculture and Industries } \\ \text { ADECA } & \text { Alabama Department of Economic and Community Affairs } \\ \text { ADEM } & \text { Alabama Department of Environmental Management } \\ \text { ARWA } & \text { Alabama Rural Water Association } \\ \text { AWURP } & \text { Alabama Water Use Reporting Program } \\ \text { CP } & \text { county population } \\ \text { DOE-EIA } & \text { U.S. Department of Energy, Energy Information Administration } \\ \text { DWB-ADEM } & \text { Drinking Water Branch, Alabama Department of Environmental } \\ \text { GIS } & \text { Management } \\ \text { GSA } & \text { geographic information system } \\ \text { HH } & \text { Geological Survey of Alabama } \\ \text { HH-PS } & \text { housing unit } \\ \text { HUC } & \text { number of housing units on public supply } \\ \text { MOR } & \text { hydrologic unit code } \\ \text { NASS } & \text { monthly operating report } \\ \text { NWUIP } & \text { National Agricultural Statistics Service (USDA) } \\ \text { OWR } & \text { National Water-Use Information Program (USGS) } \\ \text { PCTHH-PS } & \text { Office of Water Resources (Alabama) } \\ \text { P-HH } & \text { percent of housing units on public supply } \\ \text { PP-PS } & \text { persons per housing unit } \\ \text { SDWIS } & \text { population served by public supply } \\ \text { SIC } & \text { Safe Drinking Water Information System (USEPA) } \\ \text { TVA } & \text { Standard Industrial Classification } \\ \text { USDA } & \text { Tennessee Valley Authority } \\ \text { USGS } & \text { U.S. Department of Agriculture } \\ \text { USEPA } & \text { U.S. Geological Survey } \\ & \text { U.S. Environmental Protection Agency } \\ & \end{array}$





\title{
Water Use, Availability, and Net Demand in the Tennessee River Watershed within Alabama, 2005
}

\author{
By Amy C. Gill, Michael J. Harper, and Thomas M. Littlepage
}

\section{Abstract}

The U.S. Geological Survey worked in cooperation with the Alabama Department of Economic and Community Affairs-Office of Water Resources to estimate water use and water availability for 2005 for the portion of the Tennessee River watershed contained within the borders of the State of Alabama. Estimates of water use and availability are an important part of planning for population and economic growth in the Tennessee River watershed in Alabama. Total water use for the region in 2005 was 5,197 million gallons per day (Mgal/d). Total surface-water withdrawals were 5,139 Mgal/d, and total groundwater withdrawals were about $58 \mathrm{Mgal} / \mathrm{d}$. About 92 percent of the total water withdrawn was surface water used for once-through cooling for thermoelectric power generation. Self-supplied industrial and public-supply water uses accounted for the next greatest uses of water, constituting approximately 49 and 42 percent, respectively, of the total water use excluding thermoelectric power use.

Summaries of water use by county and subbasin indicated the areas of greatest water withdrawals and use within the Tennessee River watershed. Limestone (2,012 Mgal/d), Jackson (1,498 Mgal/d), and Colbert (1,363 Mgal/d) Counties were the counties with the greatest total water use in 2005 and had large amounts of water withdrawn for thermoelectric power generation. When water use from thermoelectric power generation was not considered, the counties with the greatest withdrawals were Morgan (124 Mgal/d), Madison (72 Mgal/d), Colbert (69 Mgal/d), and Lawrence (67 Mgal/d). The subbasin with the greatest total water use was Wheeler Lake (2,260 Mgal/d) in the Middle Tennessee-Elk subregion. Wheeler Lake subbasin also had the greatest public-supply, irrigation, industrial, mining, and thermoelectric withdrawals of any subbasin in the Tennessee River watershed within Alabama.

Total water availability for the Tennessee River watershed within Alabama was estimated to be $34,567 \mathrm{Mgal} / \mathrm{d}$ by the Geological Survey of Alabama. Net water demand for the watershed was calculated by subtracting the Tennessee Valley Authority estimates of return flow from water withdrawals. The net water demand was $136 \mathrm{Mgal} / \mathrm{d}$, which is less than 1 percent of the estimated water available.

\section{Introduction}

The State of Alabama is expected to experience population growth and simultaneous increased water demand during the next 25 to 30 years (The University of Alabama, Center for Business and Economic Research, 2011). Planning for the increased demand on the State's finite water supply is crucial to ensure that adequate amounts of water are available for beneficial uses. Compilations of water use have been created every 5 years for the last 55 years in the State of Alabama (MacKichan, 1951, 1957; MacKichan and Kammerer, 1961; Murray, 1968; Murray and Reeves, 1972, 1977; Solley and others, 1983, 1988, 1993, 1998; Hutson and others, 2004a, 2009). These compilations provide a record of water use through time that can be used to assess trends within the State and to evaluate probable future demands. An important further step in planning for future water demand is to link current known water use to estimates of total water availability.

The Tennessee River watershed within Alabama is a high-priority area for future water-use planning for the State of Alabama because of high water withdrawal rates, the presence of large population centers, thermoelectric power generation, industry, and the Federal interest in the flow of the river. The Tennessee River watershed historically has been intensively used for water withdrawals (Hutson and others, 2004b). In 2005, thermoelectric power generation and industrial uses in the Tennessee River watershed within Alabama accounted for 58 and 39 percent, respectively, of statewide withdrawals for those categories of use. Population of the watershed was approximately 19 percent of the statewide population, and Huntsville and Decatur, the State's fourth and eighth largest cities, respectively, are located within the watershed. The Tennessee Valley Authority (TVA) manages flow and reservoir volume along the Tennessee River to achieve goals for hydroelectric power generation, navigation, flood damage reduction, and water supply.

Water managers within the State need water-use, availability, and net demand data to adequately plan for the multiple uses of the water resources within the Tennessee River watershed. To address this need, the Alabama Department of Economic and Community Affairs - Office of Water 
Resources (ADECA-OWR) worked in cooperation with the U.S. Geological Survey (USGS) to estimate water use and availability for the watershed. For this report, data that were compiled as part of the statewide water use report in 2005 were supplemented by more detailed local data available for the Tennessee River watershed, including net demand data from the Tennessee Valley Authority and water availability estimates made by the Geological Survey of Alabama (GSA).

\section{Purpose and Scope}

This report summarizes current (2005) water use and groundwater and surface-water availability for the Tennessee River watershed into a format that can be used for initial water planning efforts. The USGS developed this summary in cooperation with the ADECA-OWR. The collection and reporting of water use and water availability information are a priority issue in the USGS Science Strategy (U.S. Geological Survey, 2007a). Water-use estimates are presented by source of supply, by water-use category, by county, and by hydrologic subregion and subbasin. Water-use information is presented as total water use and as water use for each of seven categories: public supply, residential, irrigation, livestock, industrial, mining, and thermoelectric power. Water availability estimates are provided by source of supply and hydrologic subregion and subbasin. In addition, net water demand in the Tennessee River watershed is discussed.

The Tennessee River watershed area of Alabama was chosen as a pilot for this type of watershed-based study because of the existence of previous investigations of water availability and the likelihood that the area will have substantial population growth in the coming decades (The University of Alabama, Center for Business and Economic Research, 2011). This initial assessment of water use, availability, and demand is intended to serve as a basis for designing more refined estimates in this watershed and other watersheds in the State of Alabama.

\section{Hydrologic Setting}

The Tennessee River enters northeastern Alabama from Tennessee and flows southwestward and then westward across Alabama before turning northwestward to exit the State at the northwestern corner and flow through Mississippi and Tennessee. The entire Tennessee River watershed drainage area is 40,910 square miles $\left(\mathrm{mi}^{2}\right)$ and includes parts of seven States. The Alabama portion of the watershed is $6,780 \mathrm{mi}^{2}$ or about 17 percent of the total watershed (Hutson and others, 2004b; fig. 1). The drainage area covers about 13 percent of the State of Alabama (Alabama Department of Conservation and Natural Resources, 2008) and includes all or part of 15 Alabama counties (fig. 2). Seven hydrologic subbasins of the Tennessee River watershed are completely or partially located within Alabama (fig. 3).

In Alabama, the Tennessee River is impounded by a series of dams operated by the TVA (fig. 4). On the mainstem of the Tennessee River, three dams, Guntersville, Wilson, and Wheeler, are located in Alabama, while a fourth dam, Pickwick, located in Tennessee, forms a reservoir that is largely encompassed by the State of Alabama. In addition, TVA also operates four dams (Upper Bear Creek, Little Bear Creek, Cedar Creek, and Bear Creek Dams) in the watershed of Bear Creek, a northward-flowing tributary to the Tennessee River. TVA manages the dams and associated reservoirs to provide hydroelectric power generation, navigation, flood control, water supply, and recreation. The amount of water in the Tennessee River system and its reservoirs depends on rainfall and runoff (Tennessee Valley Authority, 2012). The Guntersville, Wheeler, Wilson, Pickwick, and Bear reservoir systems regulate flow in the Tennessee River system within Alabama.

Mean annual rainfall in the Alabama portion of the Tennessee River watershed is about 58 inches. For the period 1971-2000, the average annual rainfall at weather stations in the watershed ranged from a minimum of 53.56 to a maximum of 62.55 inches (National Oceanic and Atmospheric Administration, 2009). Monthly rainfall ranged from 2.96 to 6.84 inches during that period and generally is highest in March and lowest in August and October. Annual runoff, the amount of water discharged from an area in a year, either through overland flow or discharge to streams, for the same period (1971-2000) for the Tennessee River Valley was approximately 25.6 inches (U.S. Geological Survey, 2012). Runoff and streamflow are strongly associated with storm events because of the relatively impermeable rock underlying most of the watershed area.

Groundwater resources in the watershed are represented by three aquifer systems: the Southeastern Coastal Plain aquifer system, the Valley and Ridge aquifers, and the Appalachian Plateaus and Interior Low Plateaus aquifers (Miller, 1990; fig. 5). The Southeastern Coastal Plain aquifer system in Alabama consists mostly of sand and clay layers. The aquifer system crops out in the southwestern portion of the study area and includes the Tuscaloosa Group, an unconfined aquifer with low yields. The Tuscaloosa Group is productive enough to be used as a water supply by some small communities in the Tennessee River watershed (Bossong and Harris, 1987; Miller, 1990). 


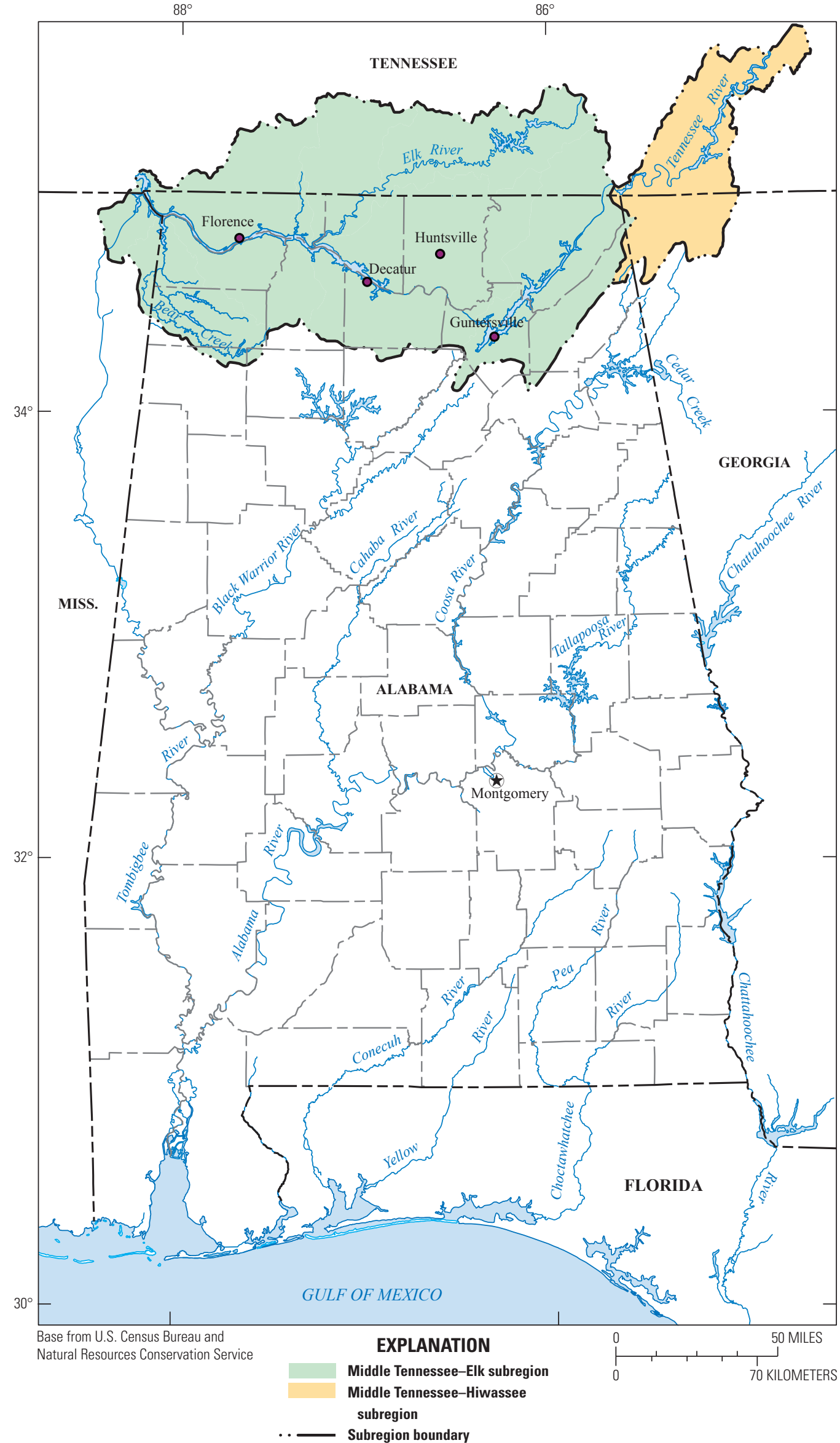

Figure 1. Hydrologic subregions, rivers, state capital, and study area cities in Alabama. 


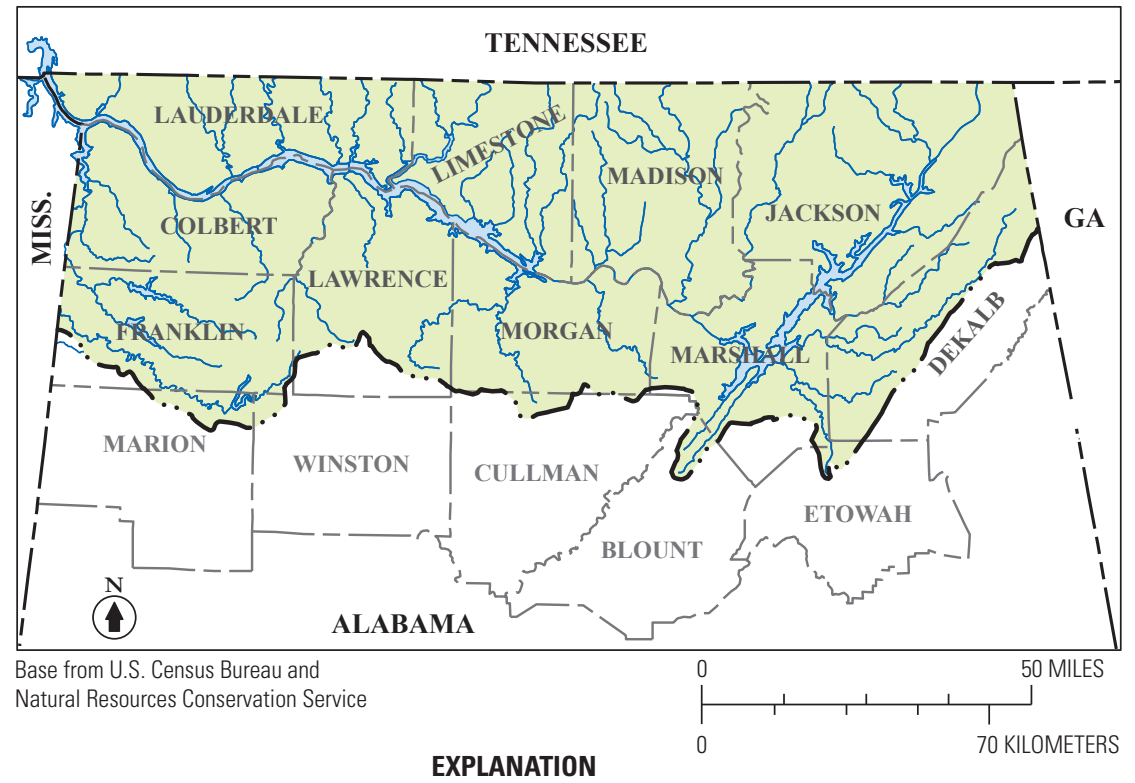

ennessee River watershed
Figure 2. Alabama counties in and partially in the Tennessee River watershed.

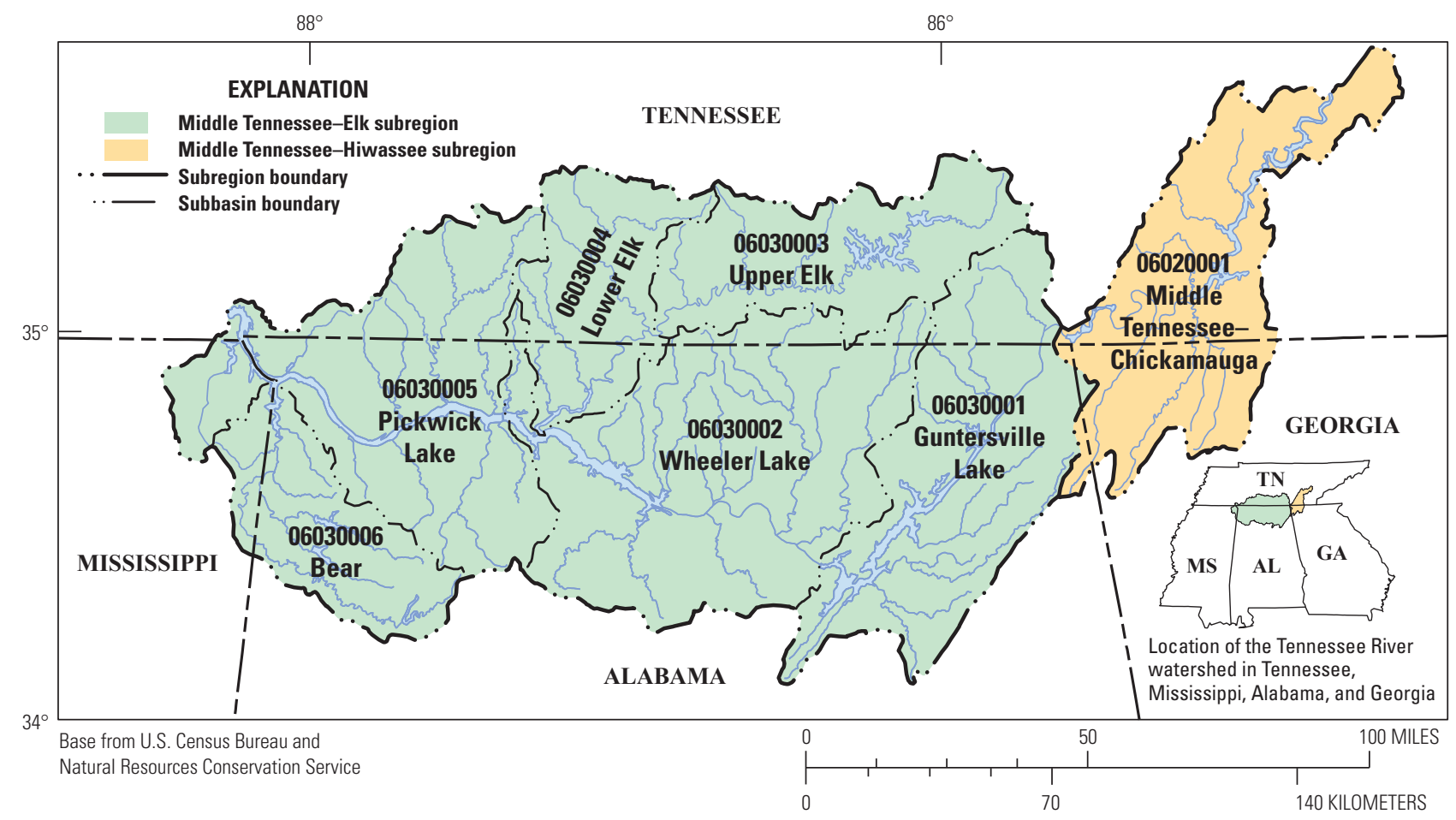

Figure 3. Subregions and subbasins of the Tennessee River watershed within Alabama. 


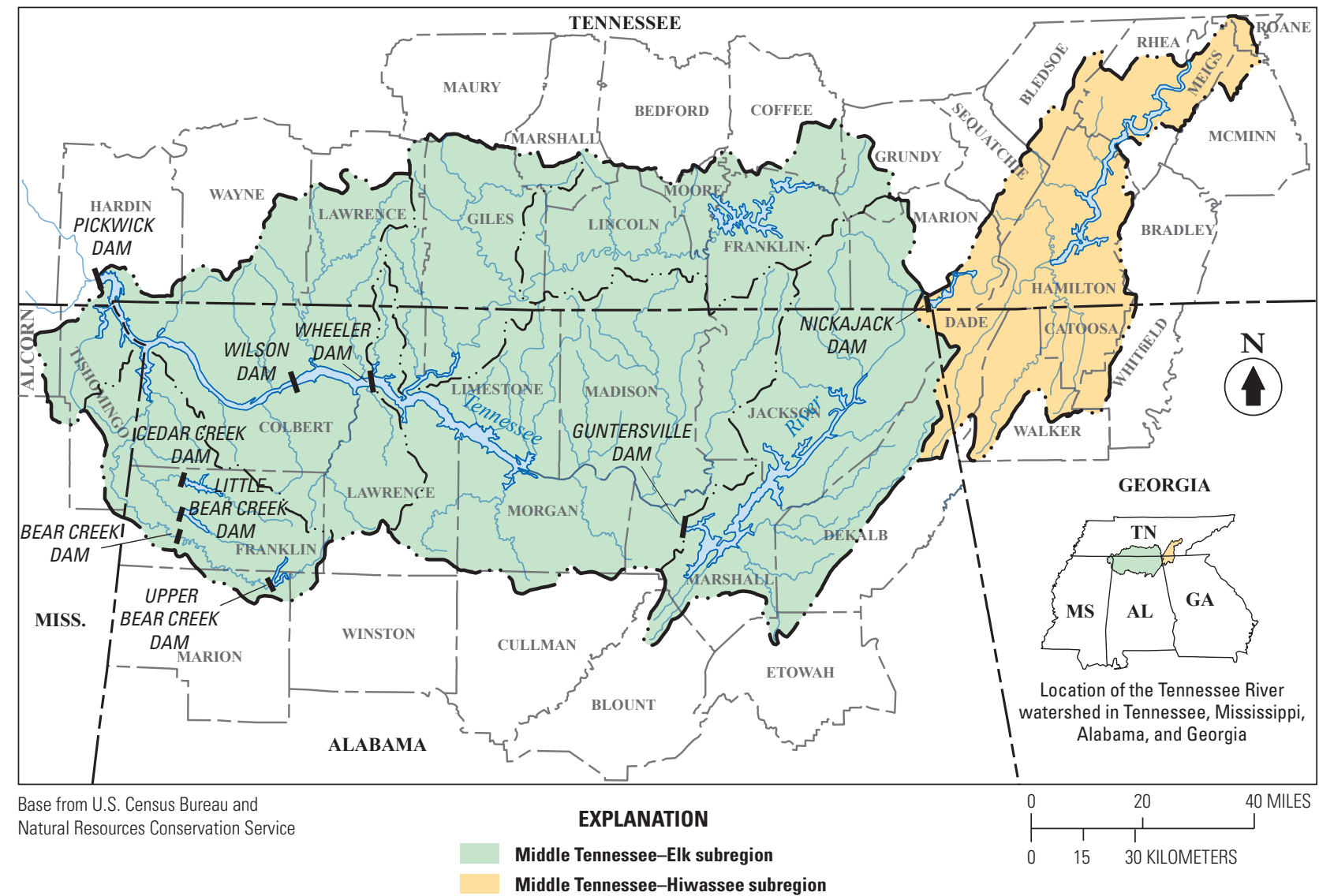

Figure 4. Location of major dams in the Tennessee River watershed in Alabama.

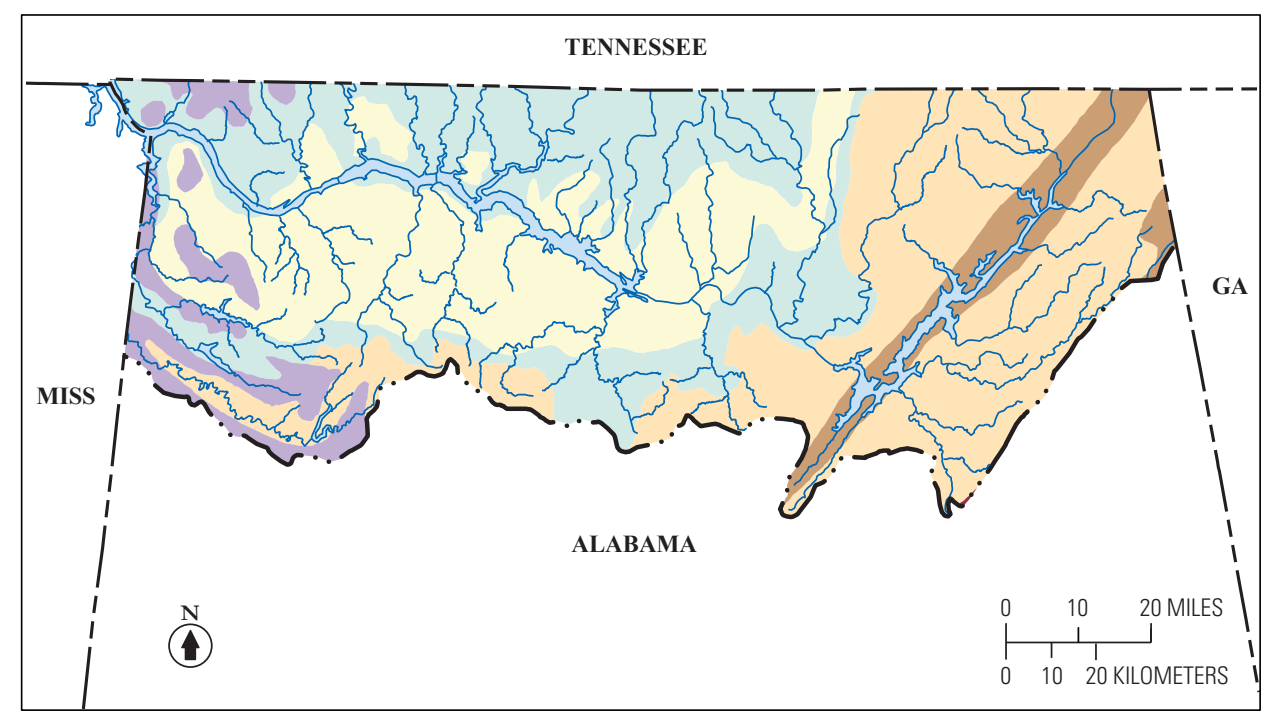

EXPLANATION

Other rocks

Southeastern Coastal Plain aquifer system

Valley and Ridge aquifers

Valley and Ridge carbonate-rock aquifers
Appalachian Plateaus and Interior Low Plateaus

Mississippian aquifers

Pennsylvanian aquifers
Figure 5. Principal aquifers in the Tennessee River watershed in Alabama. 
The Valley and Ridge aquifers are predominantly composed of limestones, dolomites, and cherts, and the groundwater production is strongly influenced by the presence of solution openings and fractures. Water stored in these solution openings may produce high well yields, but the yields are not geographically uniform across the aquifers (Bossong, 1989; Bossong and Harris, 1987; Cook and others, 2009; Miller, 1990).

In the Appalachian Plateaus and Interior Low Plateaus, many of the same limestone and dolomite formations are overlain by the Pottsville aquifer, a highly indurated and tightly cemented sandstone that crops out in the northeastern portion of the study area. The Pottsville aquifer has relatively low water yields unless local structure, such as cavities, allows for more storage; however, it can be an important source of water to domestic wells and in areas where the other aquifers are harder to access (Bossong, 1989; Cook and others, 2009; Miller, 1990).

The Tennessee River exclusively provides water to Alabama communities such as Decatur and Guntersville and supports a robust thermoelectric power generation and industrial base. Wells and springs within the Cumberland Plateau provide limited groundwater for aquaculture, industrial, mining, livestock, and self-supplied residential users (Baker, 1989; Baker and Moser, 1989; Hunter, 1991; Mooty and Richardson, 1998). Most of the groundwater use in the Tennessee River watershed is for public supply.

Table 1. Hydrologic unit codes and names, Tennessee River watershed within Alabama.

[The map boundaries for hydrologic units are hydrographically defined, and the units are often used as a geographical framework for detailed water-resources planning. The hydrologic unit code (HUC) assigned to the hydrologic unit is an 8-digit number with each 2-digit number respectively indicating region, subregion, accounting unit, and cataloging unit. The Tennessee River watershed is designated by " 06 ," and this table lists the seven hydrologic units in the watershed that are included, whole or in part, in Alabama. Subregion names are shown in bold]

\begin{tabular}{ll}
\hline \multicolumn{1}{c}{ Hydrologic unit code } & \multicolumn{1}{c}{ Subregion or subbasin name } \\
\hline $\mathbf{0 6 0 2}$ & Middle Tennessee-Hiwassee \\
06020001 & Middle Tennessee-Chickamauga \\
$\mathbf{0 6 0 3}$ & Middle Tennessee-Elk \\
06030001 & Guntersville Lake \\
06030002 & Wheeler Lake \\
06030003 & Upper Elk \\
06030004 & Lower Elk \\
06030005 & Pickwick Lake \\
06030006 & Bear \\
\hline
\end{tabular}


Table 2. Summary of data sources by water-use category and type of data for the Tennessee River watershed within Alabama.

[OWR, Alabama Department of Economic and Community Affairs, Office of Water Resources; ADEM, Alabama Department of Environmental Management; ARWA, Alabama Rural Water Association; USEPA-SDWIS, U.S. Environmental Protection Agency, Safe Drinking Water Information System; USDA-NASS, U.S. Department of Agriculture, National Agricultural Statistics Service; ADAI, Alabama Department of Agriculture and Industries; USGS-NWUIP, U.S. Geological Survey National Water-Use Information Program; DOE-EIA, U.S. Department of Energy, Energy Information Administration; TVA, Tennessee Valley Authority]

\begin{tabular}{|c|c|c|}
\hline Water-use category & Data sources & Type of data \\
\hline \multirow[t]{12}{*}{ Public supply } & OWR & Active public suppliers \\
\hline & & Monthly average-daily water withdrawals \\
\hline & & Source of water \\
\hline & & Public-supplier water deliveries by sector \\
\hline & ADEM & Active public suppliers \\
\hline & & Monthly average-daily water withdrawals \\
\hline & & Source of water \\
\hline & ARWA & Active public suppliers \\
\hline & USEPA-SDWIS & Active and inactive public suppliers \\
\hline & U.S. Census Bureau & $\begin{array}{l}\text { Total population, total number of housing units, } \\
\text { percentage of households on public supply, } 1990\end{array}$ \\
\hline & & Persons per household, 2000 \\
\hline & & County population estimates, 2005 \\
\hline \multirow[t]{4}{*}{ Residential } & OWR & Public-supplier water deliveries by sector \\
\hline & U.S. Census Bureau & $\begin{array}{l}\text { Percentage of households on public supply by } \\
\text { county, } 1990\end{array}$ \\
\hline & & Persons per household by county, 2000 \\
\hline & & County population estimates, 2005 \\
\hline \multirow[t]{4}{*}{ Irrigation } & OWR & Source of water for crops, nurseries, and sod farms \\
\hline & USDA-NASS & $\begin{array}{l}\text { Irrigated acreage and crop types by county, } 2002 \\
\text { and } 2003 \text {; application rates, sprinkler system types } \\
\text { by State, } 2002 \text { and } 2003\end{array}$ \\
\hline & ADAI & Nursery and sod farm listing \\
\hline & TheGolfCourses.net (2009) & Golf course listings and ancillary information \\
\hline Livestock & USGS-NWUIP & $\begin{array}{l}\text { County estimates of water withdrawals by source and } \\
\text { quality of water }\end{array}$ \\
\hline Mining & USGS-NWUIP & $\begin{array}{l}\text { County estimates of water withdrawals by source and } \\
\text { quality of water }\end{array}$ \\
\hline \multirow[t]{2}{*}{ Industrial } & OWR & $\begin{array}{l}\text { Some mine sites, monthly average-daily water } \\
\text { withdrawals }\end{array}$ \\
\hline & OWR & Water withdrawals by source of water \\
\hline \multirow[t]{3}{*}{ Thermoelectric power } & DOE-EIA & $\begin{array}{l}\text { Water withdrawals by source and quality of water; } \\
\text { power generation }\end{array}$ \\
\hline & OWR & Water withdrawals \\
\hline & Thermoelectric power plants & Power generation \\
\hline \multirow[t]{2}{*}{ Return flows } & TVA & Public supply, industrial, and thermoelectric \\
\hline & OWR & $\begin{array}{l}\text { Corrections to public supply, industrial, and } \\
\text { thermoelectric }\end{array}$ \\
\hline
\end{tabular}


Water withdrawals are reported by county, by four-digit hydrologic subregion, and by eight-digit subbasin levels (U.S. Department of Agriculture, Soil Conservation Service, 1993; U.S. Department of Agriculture, 2004; U.S. Geological Survey, 2007b). Results are reported for all 15 counties and for 6 of the subbasins within the study area. The seventh subbasin, the Upper Elk (06030003), has an area of less than $1 \mathrm{mi}^{2}$ within Alabama. Estimated water use in the Upper Elk subbasin within Alabama rounded to zero for all calculated values in this report; therefore, the Upper Elk subbasin was omitted from all water-use tables and figures herein. Annual water use is expressed in terms of million gallons per day (Mgal/d). Water use is normalized as a per capita use statistic (gallons per capita per day) in five ways.

- Total water use is divided by the total population to yield gross per capita use and includes water used to generate electricity, support industrial and agricultural activities, and provide drinking water.

- Public-supply water use is divided by the population served by public suppliers to yield gross publicsupply per capita use and includes water delivered to the residential, industrial, commercial, and thermoelectric power sectors and public use and losses.

- Public-supply residential deliveries are divided by the population served to yield public-supplied residential per capita use.

- Self-supplied residential water withdrawals are divided by self-supplied population to yield self-supplied residential per capita use.

- Public-supplied residential deliveries plus self-supplied residential withdrawals are divided by the total population to yield residential per capita use.

In the tables, State, county, subregion, subbasin, and facility data are rounded to hundredths. In the text, water withdrawal totals are reported as whole numbers unless the use of decimals is needed to improve clarity. Percentages are based on the rounded values presented in the tables and are expressed as whole numbers. All values are rounded independently; therefore, the sums of individually rounded numbers may not equal the totals given in this report.

\section{Total Population}

The 2005 estimate of population by subbasin was derived from the 2000 and 2005 county census numbers (U.S. Census Bureau, Geography Division, 2001; U.S. Census Bureau, 2006b). A county-level percentage of change in population between 2000 and 2005 was determined from reported populations. Using geographic information system (GIS) spatial techniques, the percentage of change in population was applied to each 2000 census block group to estimate a 2005 block-group population (U.S. Census Bureau, Geography Division, 2001). The 2005 block-group population estimate then was used to calculate a population per unit area for each block group. Block groups were clipped to the subbasin by using GIS techniques, and the population per unit area for each block group was multiplied by the area of the partial block group contained within the subbasin. The resulting partial block-group populations were summed to determine a population in the areas within both the county and subbasin and then to determine the total subbasin population. Using this methodology, the total population summarized by subbasin was 0.004 percent ( 31 people) less than the population summarized by county. An attempt was made to balance the subbasin and county population estimates. First, populations reported for the Upper Elk hydrologic subbasin (Hydrologic Unit Code (HUC) 06030003) were removed after examination of aerial photography indicated no residences within the portion of the subbasin within the State of Alabama. Then the difference between the remaining estimates was minimized by adding people to the affected subbasins based on the proportions of county population calculated within them. A difference of one person remained after these corrections were applied. The discrepancy was due to methodology and rounding and was not adjusted further.

Populations used in this report differ somewhat from the populations reported in Hutson and others (2009) because of the difference in GIS techniques that were used to estimate population distribution. In Hutson and others (2009), blockgroup populations were assigned to their centroids, and in this report, the population of each block group was assumed to be evenly areally distributed. These differences in population estimates cause minor differences between the two reports in the per capita use estimates for hydrologic subbasins.

\section{Public-Supply and Residential Water Use}

For public supply, groundwater and surface-water withdrawals were reported at the county and subbasin levels, and residential deliveries and population served were estimated at the county level. Public-supply withdrawal estimates mostly were based on site-specific data (table 2). Raw-water pumpage, or the finished-water production upon which water withdrawals were estimated, was metered and reported as average-daily rates of withdrawal for each month to Alabama OWR through mandatory yearly Alabama Water Use Reporting Program (AWURP) reports and to the Drinking Water Branch-Alabama Department of Environmental Management (DWB-ADEM) through mandatory monthly operation reports (MORs). Water sold to or purchased from other public suppliers was not included in this study. To ensure that the water withdrawals were compiled for the geographical area in which the withdrawals occurred, the county and subbasin locations of the water plants, surface-water intakes, wells, or well fields were verified using GIS techniques. A comprehensive list of 
public suppliers was compiled from records from Alabama OWR, DWB-ADEM, Alabama Rural Water Association (ARWA), and the Internet-based Safe Drinking Water Information System (SDWIS) maintained by the U.S. Environmental Protection Agency (USEPA; U.S. Environmental Protection Agency, 2009).

For the statewide report, residential deliveries were based on a survey of the public suppliers that was conducted by Alabama OWR (Hutson and others, 2009). More than 60 percent of the suppliers responded, including all of the suppliers serving 50,000 people or more. Responses from public suppliers were used to estimate residential deliveries for public suppliers with similar demographic and geographic characteristics who had not responded. Residential deliveries were estimated at the county level from average monthly consumption for residential customers (per household use coefficient; reported by the public suppliers) in the county and the number of households in the county (calculated from U.S. Census Bureau population and persons per household data). Water withdrawals and residential deliveries were counted in the county or subbasin in which the water withdrawal occurred. Distribution areas of public suppliers were not mapped, and some deliveries may occur across county lines. Therefore, in this report, even though total public-supply withdrawals represent a summary of the best available data, significant errors in the presentation of the geographic summary of water deliveries may exist.

Residential water use is the sum of residential deliveries plus self-supplied residential withdrawals. Self-supplied residential withdrawals were not reported as part of the AWURP and were not collected as part of this study. Instead, self-supplied residential withdrawals were estimated from a self-supplied population and a per household use coefficient for each county. The self-supplied population was divided by the number of persons per household in 2000 to yield the number of self-supplied housing units in 2005 . The per household use coefficients for rural households were derived from a subset of the OWR Alabama Water System Survey consisting of the small public suppliers with primarily rural residential deliveries. Self-supplied households were assumed to use the same amount of water as public-supplied rural households. For 2005, the average monthly rural household use by county ranged from 126 gallons per day (gal/d) to $300 \mathrm{gal} / \mathrm{d}$ in the Tennessee River watershed in Alabama.

\section{Population Served and Self-Supplied Residential Population}

No reliable estimates of population served by public supplier were available for 2005 (U.S. Environmental Protection Agency, 2009). Population served by public supplier, therefore, was estimated using the 1990 county census population numbers, number of housing units, and percentage of housing units on public supply (U.S. Census Bureau, 1992) and the
2005 county census population (U.S. Census Bureau, 2006a; table 2). The change in county population from 1990 to 2005 is a proxy for the change in the number of housing units on public supply during the same period. The methodology for estimating the 2005 population served assumes that any population increase from 1990 to 2005 was served by a public supplier. A simplified example of this method is as follows. The percentage of population served by public supply in the following example county increased from 60 percent in 1990 to 73 percent $(11,000$ population served in 2005 divided by 2005 county population, 15,000 ) in 2005 .

For an example county in Alabama

Census Data

\begin{tabular}{ll}
1990 CP & 10,000 \\
1990 HH, total & 2,000 \\
1990 PCTHH-PS & 60 \\
1990 P-HH & 5 \\
2005 CP & 15,000 \\
\multicolumn{2}{c}{ Calculations } \\
1990 HH-PS HH H $H_{1990} *$ & PCTHH-PS 1990 \\
$1,200 \quad 2,000 *$ & 0.6
\end{tabular}

1990 PP-PS $\quad H H-P S_{1990} * P-H H$

$6,000 \quad 1,200 * 5$

$\begin{array}{ll}2005 P P-P S & P P-P S_{1990}+\left(C P_{2005}-C P_{1990}\right) \\ 11,000 & 6,000+(15,000-10,000)\end{array}$

where

$C P \quad$ is county population for years 1990 and 2005,

$\mathrm{HH} \quad$ is number of housing units for year 1990,

PCTHH-PS is percent housing units on public supply for year 1990,

$\mathrm{P}-\mathrm{HH} \quad$ is persons per housing unit for year 1990,

$H H-P S \quad$ is number of housing units on public supply in 1990, and

$P P-P S \quad$ is population served by public supply for years 1990 and 2005.

Self-supplied population was calculated as the difference between total county population and total county population served by public suppliers. In the case of partial counties in the Tennessee River watershed, self-supplied population was estimated in one of two ways. If one or more public suppliers were located within the partial county, then the total population was divided between public supplied and self-supplied in the same proportions as in the entire county. If no public supplier was located in the partial county, then all of the population was assumed to be self-supplied. 


\section{Irrigation}

The irrigation category consists of surface-water and groundwater withdrawals for crops, nurseries, sod farms, and golf courses. At the statewide level, estimates of water withdrawals by county for crops, nurseries, and sod farms, and water withdrawals for golf courses were derived independently using data from multiple sources (Hutson and others, 2009). For this report, county-level irrigation withdrawals were estimated by multiplying the percentage of total county area contained within the Tennessee River watershed by the total county withdrawals reported in Hutson and others (2009). County-level withdrawals for irrigation were reported for the total irrigated lands, which were not specified by type.

\section{Livestock and Mining}

In this report, county-level water withdrawals by source for livestock were modified from estimates determined by the USGS National Water-Use Information Program (NWUIP) because livestock withdrawals are not reported as a specific category within the AWURP and site-specific data were not collected as part of this study. For the NWUIP, estimates of livestock withdrawals by county were calculated from the 2005 livestock census by the U.S. Department of Agriculture, National Agricultural Statistics Service (USDA-NASS) and from statewide drinking water-requirement coefficients for individual livestock types (Kammerer, 1976; Mooty and Richardson, 1998). The coefficients do not reflect the effect of climate on animal watering across the State or facility maintenance needs. In this report, NWUIP estimates were used for counties entirely contained within the Tennessee River watershed. Livestock water-use estimates for partial counties were made by multiplying livestock water use for the entire county by the percentage of county area contained within the Tennessee River watershed. For source estimation in partial counties, groundwater and surface-water sources of water used for livestock were assumed to account for the same percentages of water use as in the entire county.

Water withdrawals for livestock by subbasin were determined by applying GIS techniques. The subbasin boundaries were superimposed on the county boundaries to create a subbasin/county areal unit. Each subbasin/county unit represents a percentage of the subbasin area within a county. Surface-water and groundwater withdrawals were distributed among the subbasin/county units based on the assigned areal percentage. Water withdrawals for each subbasin/county unit were summarized by subbasin. Total groundwater withdrawal estimates by county were $0.01 \mathrm{Mgal} / \mathrm{d}$ greater than total groundwater withdrawal estimates by subbasin. No attempt was made to make the county and subbasin total withdrawal estimates equal because the difference in totals was due to methodology and rounding differences between the two estimates.
County-level water withdrawals by source for mining were modified from estimates determined by the USGS NWUIP and site-specific data from the AWURP. Mining water use was estimated from per ton water-use coefficients and crude ore production in tons for 2004 from the USGS Minerals Information Team, from coal production in tons from the U.S. Department of Energy, Energy Information Administration (DOE-EIA), and from site-specific mining withdrawal data reported to the AWURP. Mining water-use estimates for partial counties in the Tennessee River watershed were made by multiplying mining water use for the entire county by the percentage of county area contained within the Tennessee River watershed. Mining water-use estimates were available at the county level only, so for source estimation in partial counties, groundwater and surface-water sources were assumed to account for the same percentages of water use as in the entire county.

\section{Thermoelectric Power and Industrial}

Thermoelectric power and industrial water use were estimated from site-specific data. The primary sources of data for thermoelectric power water withdrawals and power produced were the DOE-EIA, the AWURP database eWater, and the individual thermoelectric power facilities (table 2). Water withdrawals were reported in the county or subbasin in which the withdrawals occurred.

The AWURP database, eWater, stores monthly average- daily water withdrawals, source of water, and location information. For 2005, steam-electric plants with a nameplate capacity of 100 megawatts or more provided information about cooling type, water withdrawal, return flow, and consumptive use by generating unit (except for nuclear power plants) to DOE-EIA, and all power plants provided power generation by generating unit (Energy Information Administration, 2008, 2009a, 2009b).

Monthly self-supplied industrial withdrawals by source were reported by individual industries to the AWURP for 2005. Standard Industrial Classification (SIC) codes for those industries were obtained from the Alabama Directory of Manufacturers (Alabama Development Office, 2004). Publicsupplied industrial deliveries were not available at the watershed level.

\section{Return Flow and Net Water Demand}

Return flow is water returned to a groundwater or surface-water source after release from the point of use. Return flow data for public supply, self-supplied industrial, and thermoelectric water uses were compiled and reported by the TVA. Data were checked and revised where necessary to reflect more detailed data available in ADECA-OWR files. Livestock and irrigation water uses were assumed to be 
entirely consumptive. Data were not available for return flows from self-supplied residential and mining water uses, so these uses were also treated in this report as entirely consumptive. Net water demand is the difference between a water withdrawal and the associated return flow. Return flow and net water demand totals by county and subbasin have been incorporated into the water-use tables in this report.

\section{Water Use}

\section{Total Water Use}

Total water use in the Tennessee River watershed within Alabama for 2005 was determined from estimates of water withdrawals for seven categories_-public supply (including deliveries to the other water use categories), residential, irrigation, livestock, industrial, mining, and thermoelectric power (fig. 6). All seven categories were estimated for the counties in the watershed, and all categories except self-supplied residential were estimated for hydrologic units in the watershed. Reported total water use by hydrologic unit is less than the reported total by county because it does not include the estimate for self-supplied residential water use (tables 3 and 4). For 2005, all withdrawals in the Tennessee River watershed were considered to be freshwater. Total withdrawals were estimated to be 5,197 Mgal/d (table 3). Estimates of withdrawals by source indicate that total surface-water withdrawals were 99 percent of the total $(5,139 \mathrm{Mgal} / \mathrm{d})$, and the remaining 1 percent was from groundwater (58 Mgal/d; fig. 7). Gross per capita use averaged 6,056 gal/d for the 858,097 residents in the Alabama portion of the Tennessee River watershed (U.S. Census Bureau, 2006a). Gross per capita use is the total water withdrawn divided by the total population. The large per capita use is a result of the large thermoelectric power withdrawals in relation to the population size. Total residential water use, which is a combination of residential deliveries from public supply and self-supplied residential withdrawals, was about $75 \mathrm{Mgal} / \mathrm{d}$ (see the "Residential" section in this report).

The geographic distributions of total, groundwater, and surface-water withdrawals by county and by hydrologic subbasin are shown in figures 8 and 9. The largest total water withdrawals occurred in Limestone, Jackson, and Colbert Counties. Withdrawals in these counties were approximately 94 percent of the total withdrawals in the study area and were primarily used for the cooling needs at thermoelectric power plants. Excluding thermoelectric power, the largest withdrawals occurred in Morgan, Madison, Colbert, and Lawrence Counties (table 5).

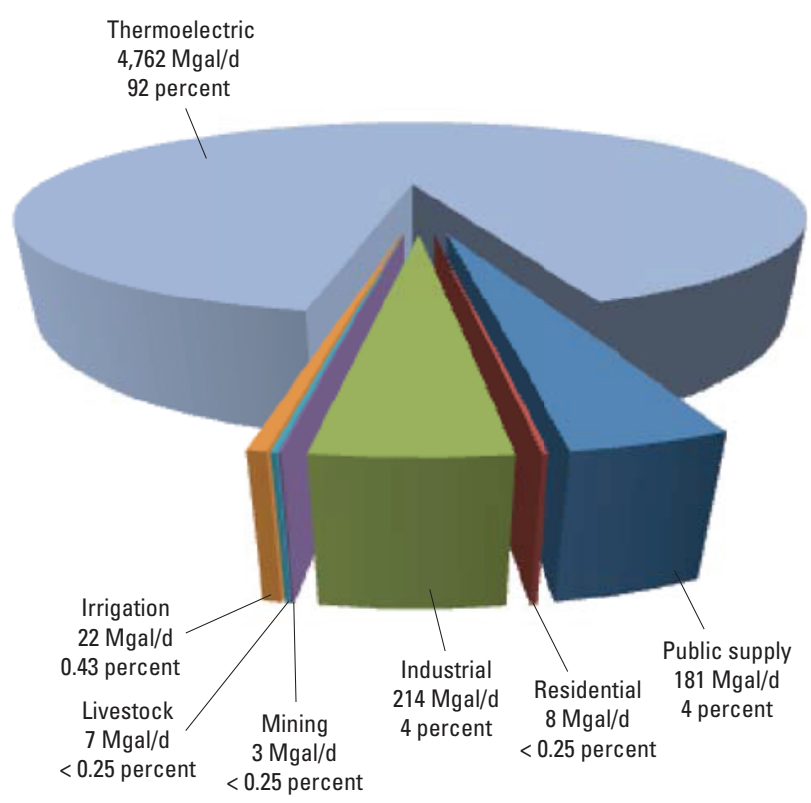

Figure 6. Comparison of freshwater withdrawals by category of use in the Tennessee River watershed within Alabama, 2005.

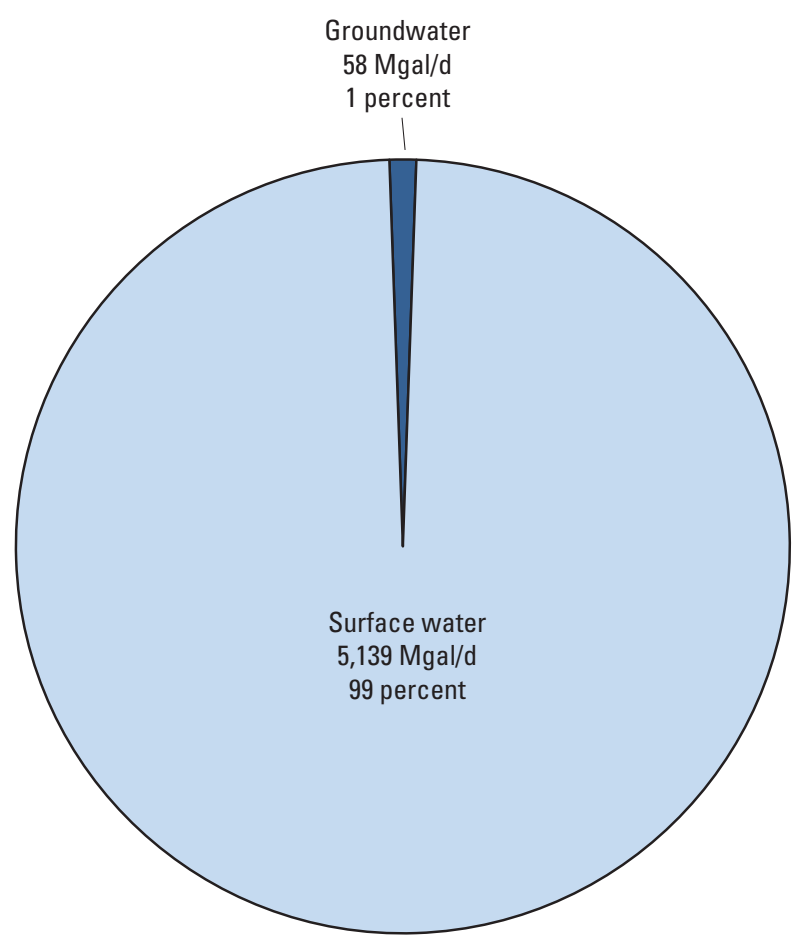

Figure 7. Sources of water used in the Tennessee River watershed in Alabama, 2005. 


\section{Water Use, Availability, and Net Demand in the Tennessee River Watershed within Alabama, 2005}

Table 3. Total freshwater withdrawals and consumption by source and county in the Tennessee River watershed within Alabama, 2005.

[Figures may not sum to totals because of independent rounding; County names in bold type indicate counties entirely contained in the watershed]

\begin{tabular}{|c|c|c|c|c|c|}
\hline \multirow{2}{*}{ County } & \multicolumn{3}{|c|}{ Withdrawals, in million gallons per day } & \multirow{2}{*}{$\begin{array}{c}\text { Return flows, } \\
\text { in million gallons } \\
\text { per day }\end{array}$} & \multirow{2}{*}{$\begin{array}{c}\begin{array}{c}\text { Consumption, in } \\
\text { million gallons per day }\end{array} \\
\text { Net water demand } \\
\end{array}$} \\
\hline & Groundwater & Surface water & Total & & \\
\hline Blount & 0.17 & 0.04 & 0.21 & 0.00 & 0.21 \\
\hline Colbert & 3.54 & $1,359.60$ & $1,363.14$ & $1,350.67$ & 12.47 \\
\hline Cullman & 0.40 & 0.07 & 0.47 & 0.00 & 0.47 \\
\hline DeKalb & 2.65 & 2.00 & 4.65 & 0.00 & 4.65 \\
\hline Franklin & 2.07 & 4.66 & 6.73 & 3.71 & 3.02 \\
\hline Jackson & 1.97 & $1,496.26$ & $1,498.23$ & $1,489.64$ & 8.59 \\
\hline Lauderdale & 3.64 & 13.50 & 17.14 & 9.68 & 7.46 \\
\hline Lawrence & 1.21 & 65.70 & 66.91 & 53.50 & 13.41 \\
\hline Marshall & 4.01 & 22.33 & 26.34 & 10.46 & 15.88 \\
\hline Morgan & 2.41 & 122.29 & 124.70 & 112.68 & 12.02 \\
\hline Winston & 0.15 & 0.01 & 0.16 & 0.00 & 0.16 \\
\hline Total & $\mathbf{5 7 . 5 4}$ & $5,139.16$ & $5,196.70$ & $5,061.29$ & 135.73 \\
\hline
\end{tabular}

Table 4. Total freshwater withdrawals and consumption by source and by hydrologic subregion and subbasin in the Tennessee River watershed within Alabama, 2005.

[Figures may not sum to totals because of independent rounding]

\begin{tabular}{|c|c|c|c|c|c|c|}
\hline \multirow{2}{*}{\multicolumn{2}{|c|}{ Hydrologic subregion and subbasin }} & \multicolumn{3}{|c|}{$\begin{array}{c}\text { Withdrawals, } \\
\text { in million gallons per day }\end{array}$} & \multirow{2}{*}{$\begin{array}{l}\text { Return flows, in } \\
\text { million gallons } \\
\text { per day }\end{array}$} & \multirow{2}{*}{$\begin{array}{c}\begin{array}{c}\text { Consumption, in } \\
\text { million gallons } \\
\text { per day }\end{array} \\
\text { Net water demand }\end{array}$} \\
\hline & & Groundwater & Surface water & Total & & \\
\hline \multicolumn{7}{|c|}{ Middle Tennessee-Hiwassee } \\
\hline 06020001 & Middle Tennessee-Chickamauga & 0.77 & 0.16 & 0.93 & 0.00 & 0.93 \\
\hline \multicolumn{7}{|c|}{ Middle Tennessee-Elk } \\
\hline 06030001 & Guntersville Lake & 5.58 & $1,519.87$ & $1,525.45$ & $1,499.09$ & 26.36 \\
\hline 06030002 & Wheeler Lake & 35.62 & $2,224.02$ & $2,259.64$ & $2,197.07$ & 62.57 \\
\hline 06030004 & Lower Elk & 0.81 & 11.43 & 12.24 & 0.11 & 12.13 \\
\hline Subtotal & & 49.01 & $5,138.99$ & $5,188.00$ & $5,061.28$ & 126.72 \\
\hline Total & & 49.78 & $5,139.15$ & $5,188.93$ & $5,061.28$ & 127.65 \\
\hline
\end{tabular}


Total
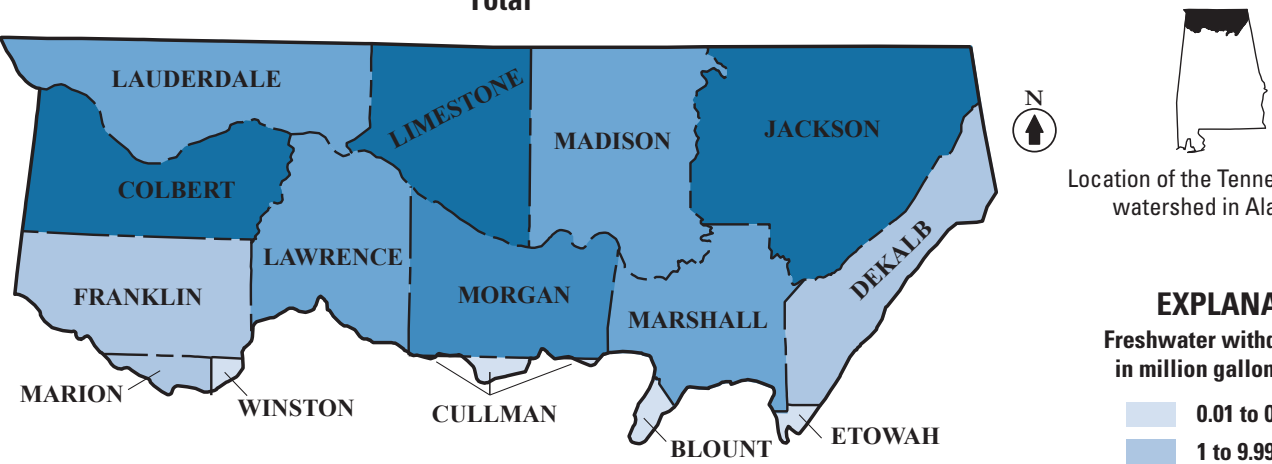

Location of the Tennessee River watershed in Alabama

\section{EXPLANATION}

Freshwater withdrawals by county, in million gallons per day

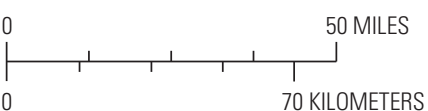

0.01 to 0.99

1 to 9.99

10 to 99.99

100 to 999.99

1,000 to 2,015

\section{Groundwater}

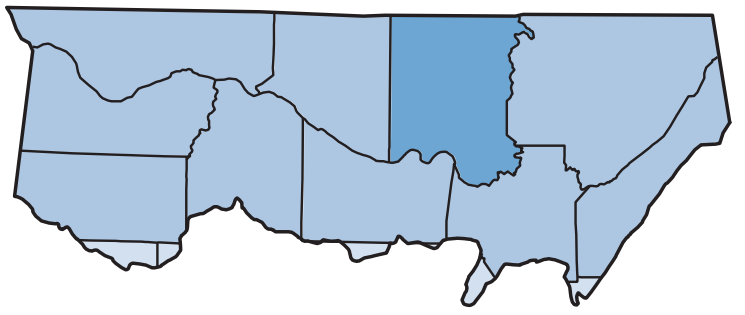

Surface water

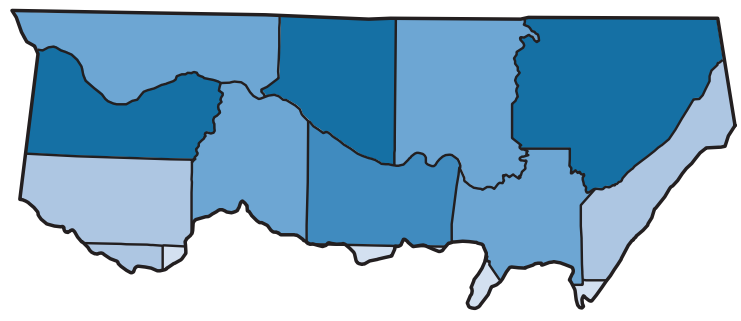

Figure 8. Total freshwater withdrawals by source and county in the Tennessee River watershed in Alabama, 2005.

Total
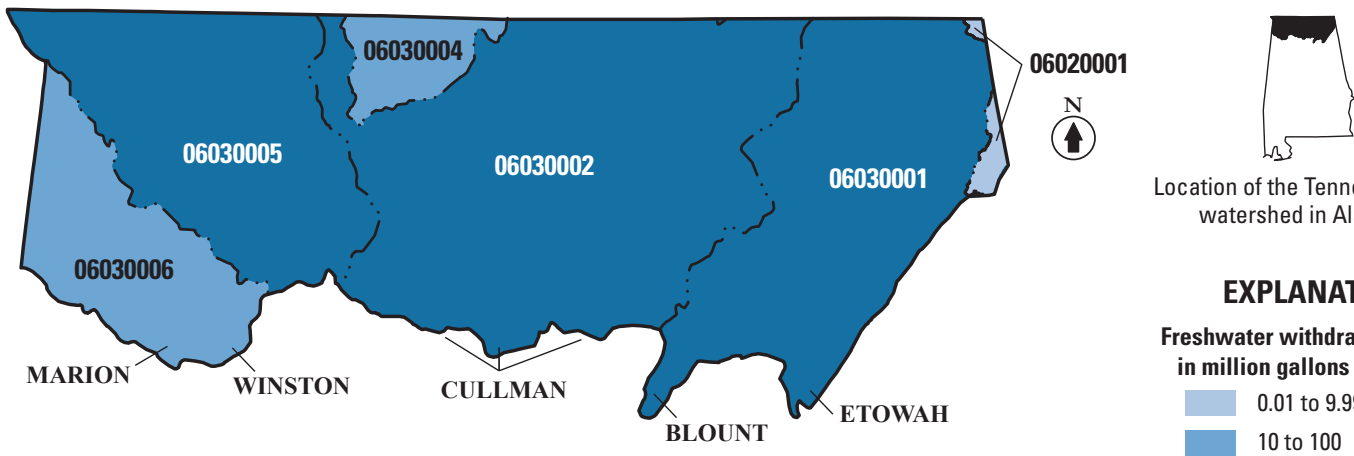

Location of the Tennessee River

watershed in Alabama

\section{EXPLANATION}

Freshwater withdrawals by subbasin,

in million gallons per day

0.01 to 9.99

10 to 100

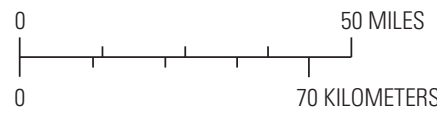

1,000 to 2,500

70 KILOMETERS

\section{Groundwater}

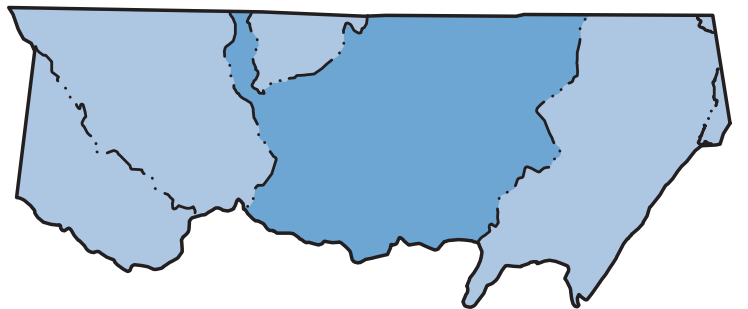

Surface water

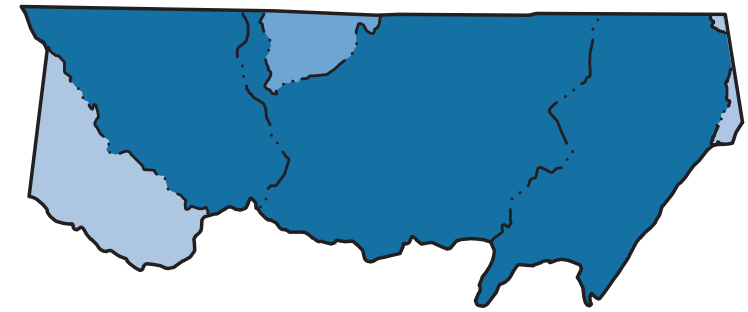

Figure 9. Total freshwater withdrawals by source and hydrologic subbasin in the Tennessee River watershed in Alabama, 2005. 
Total withdrawals by source and category for counties and hydrologic subbasins are listed in tables 3-6. For 2005, thermoelectric power accounted for 92 percent of the total water withdrawals, or 4,762 Mgal/d (tables 5 and 6; fig. 6). Combined, the public-supply and self-supplied industrial categories accounted for about 8 percent of the total withdrawals (181 Mgal/d and $214 \mathrm{Mgal} / \mathrm{d}$, respectively), and irrigation, self-supplied residential, livestock, and mining accounted for the remaining less than 1 percent. More surface water than groundwater was used in all categories except mining and selfsupplied residential (tables 7-10). About 93 percent of the surface-water withdrawals were for thermoelectric power, and the largest surface-water withdrawals were in Limestone County (table 7). About 95 percent of the surface-water withdrawals - primarily used for thermoelectric power-occurred in Limestone, Jackson, Colbert Counties in the Middle Tennessee-Elk subregion (tables 7 and 8). Most of the groundwater withdrawals, 62 percent, were used for public supply (tables 9 and 10). About 50 percent (29 Mgal/d) of the watershed-wide groundwater use was in Madison County; most of that water (88 percent) was used for public supply.

Estimates of public-supply, irrigation, livestock, selfsupplied industrial, mining, and thermoelectric power withdrawals by source of water for hydrologic subregion and subbasin and are listed in tables 6,8 , and 10 . These categories accounted for more than 99 percent $(5,189 \mathrm{Mgal} / \mathrm{d})$ of the total estimated withdrawals. The exclusion of the small withdrawal amounts for self-supplied residential (8 Mgal/d in 2005) by subbasin does not affect the understanding of the overall distribution pattern of water use in the Tennessee River watershed in Alabama. The Middle Tennessee-Elk subregion accounted for almost all of the 5,189 Mgal/d total estimated withdrawals. About 92 percent of that water was for thermoelectric power, and nearly all of the water was surface water. The second largest use category in the Tennessee River watershed was self-supplied industrial, which accounted for about 50 percent (214 Mgal/d) of the nonpower water withdrawal. 
Table 5. Total freshwater withdrawals by category of use and county in the Tennessee River watershed within Alabama, 2005.

[Figures may not sum to totals because of independent rounding. County names in bold type indicate counties entirely contained in the watershed]

\begin{tabular}{|c|c|c|c|c|c|c|c|c|c|}
\hline \multirow[b]{2}{*}{ County } & \multicolumn{9}{|c|}{ Withdrawals, in million gallons per day } \\
\hline & $\begin{array}{l}\text { Public } \\
\text { supply }\end{array}$ & Residential & Irrigation & Livestock & Industrial & Mining & $\begin{array}{c}\text { Subtotal } \\
\text { without } \\
\text { thermoelectric }\end{array}$ & Thermoelectric & Total \\
\hline Blount & 0.00 & 0.10 & 0.03 & 0.04 & 0.00 & 0.04 & 0.21 & 0.00 & 0.21 \\
\hline Colbert & 9.56 & 0.31 & 2.34 & 0.30 & 56.44 & 0.05 & 69.00 & $1,294.14$ & $1,363.14$ \\
\hline Cullman & 0.00 & 0.28 & 0.07 & 0.12 & 0.00 & 0.00 & 0.47 & 0.00 & 0.47 \\
\hline Etowah & 0.00 & 0.23 & 0.04 & 0.02 & 0.00 & 0.00 & 0.29 & 0.00 & 0.29 \\
\hline Franklin & 4.70 & 0.31 & 0.45 & 0.70 & 0.00 & 0.57 & 6.73 & 0.00 & 6.73 \\
\hline Jackson & 10.71 & 0.91 & 0.71 & 0.72 & 8.78 & 0.10 & 21.93 & $1,476.30$ & $1,498.23$ \\
\hline Lauderdale & 14.19 & 1.30 & 1.17 & 0.48 & 0.00 & 0.00 & 17.14 & 0.00 & 17.14 \\
\hline Marion & 3.17 & 0.11 & 0.01 & 0.04 & 0.00 & 0.00 & 3.33 & 0.00 & 3.33 \\
\hline Marshall & 24.14 & 0.29 & 0.57 & 1.02 & 0.04 & 0.28 & 26.34 & 0.00 & 26.34 \\
\hline Morgan & 30.42 & 0.30 & 0.86 & 0.73 & 90.65 & 0.54 & 123.50 & 1.20 & 124.70 \\
\hline Winston & 0.00 & 0.14 & 0.00 & 0.02 & 0.00 & 0.00 & 0.16 & 0.00 & 0.16 \\
\hline Total & 180.93 & 7.78 & 22.29 & 6.82 & 213.98 & 3.01 & 434.81 & $4,761.88$ & $5,196.69$ \\
\hline
\end{tabular}

Table 6. Total freshwater withdrawals by category of use and hydrologic subregion and subbasin in the Tennessee River watershed within Alabama, 2005.

[Figures may not sum to totals because of independent rounding. All values are in million gallons per day]

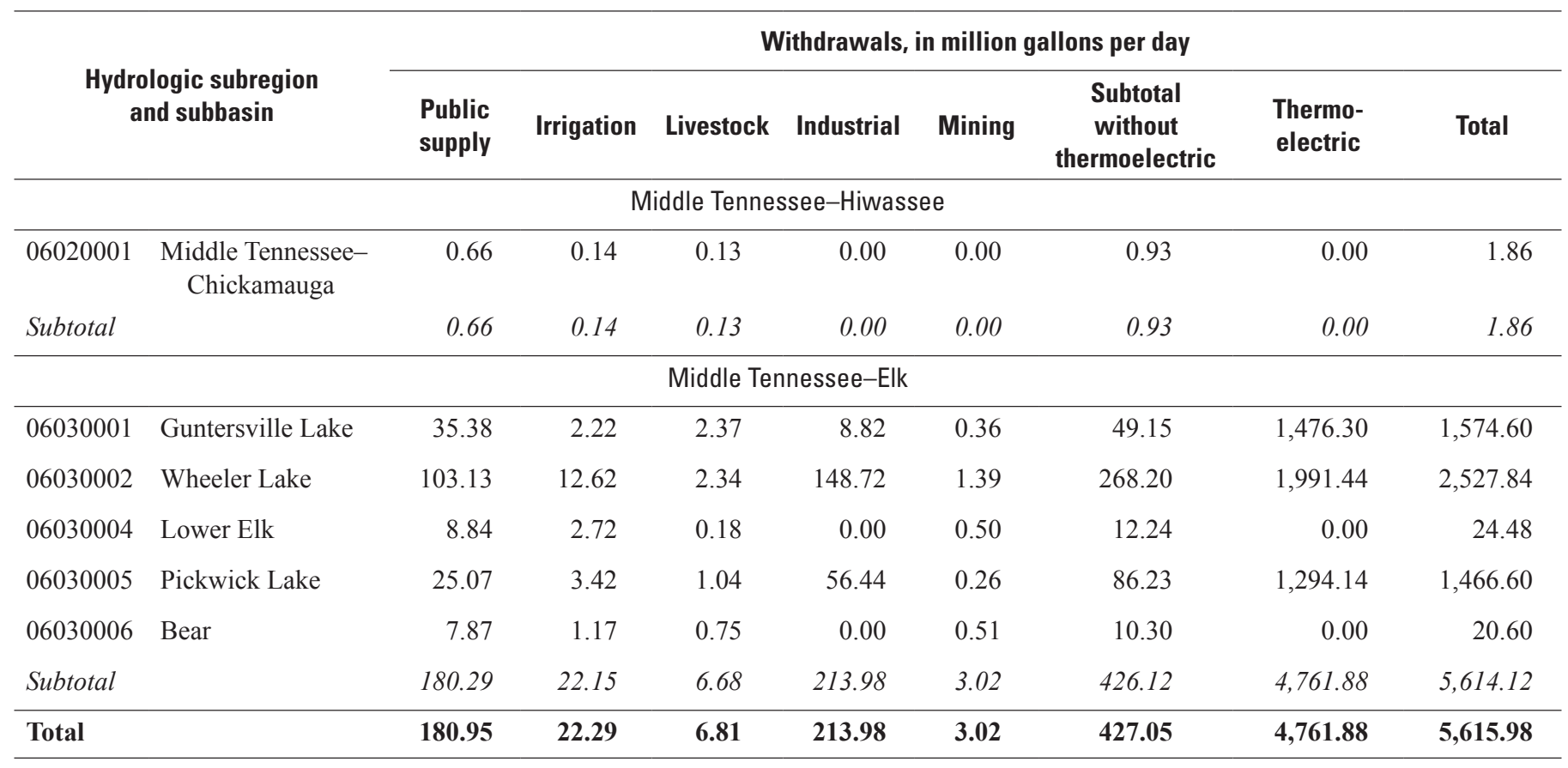


Table 7. Total surface-water withdrawals by category of use and county in the Tennessee River watershed within Alabama, 2005.

[Figures may not sum to totals because of independent rounding. County names in bold type indicate counties that are entirely contained within the watershed]

\begin{tabular}{|c|c|c|c|c|c|c|c|}
\hline County & \multicolumn{7}{|c|}{ Surface-water withdrawals, in million gallons per day } \\
\hline Blount & 0.00 & 0.02 & 0.02 & 0.00 & 0.00 & 0.00 & 0.04 \\
\hline Colbert & 8.27 & 1.40 & 0.17 & 55.57 & 0.05 & $1,294.14$ & $1,359.60$ \\
\hline Cullman & 0.00 & 0.01 & 0.06 & 0.00 & 0.00 & 0.00 & 0.07 \\
\hline DeKalb & 0.47 & 0.88 & 0.65 & 0.00 & 0.00 & 0.00 & 2.00 \\
\hline Franklin & 3.88 & 0.20 & 0.40 & 0.00 & 0.18 & 0.00 & 4.66 \\
\hline Jackson & 10.08 & 0.67 & 0.40 & 8.78 & 0.03 & $1,476.30$ & $1,496.26$ \\
\hline Lauderdale & 12.79 & 0.43 & 0.28 & 0.00 & 0.00 & 0.00 & 13.50 \\
\hline Lawrence & 6.91 & 1.18 & 0.36 & 57.18 & 0.07 & 0.00 & 65.70 \\
\hline Marshall & 21.16 & 0.57 & 0.51 & 0.00 & 0.09 & 0.00 & 22.33 \\
\hline Morgan & 30.42 & 0.74 & 0.40 & 89.36 & 0.17 & 1.20 & 122.29 \\
\hline Winston & 0.00 & 0.00 & 0.01 & 0.00 & 0.00 & 0.00 & 0.01 \\
\hline Total & 144.85 & 15.61 & 3.73 & 211.78 & 1.31 & $4,761.88$ & $5,139.16$ \\
\hline
\end{tabular}

Table 8. Total surface-water withdrawals by category of use and hydrologic subregion and subbasin in the Tennessee River watershed within Alabama, 2005.

[Figures may not sum to totals because of independent rounding]

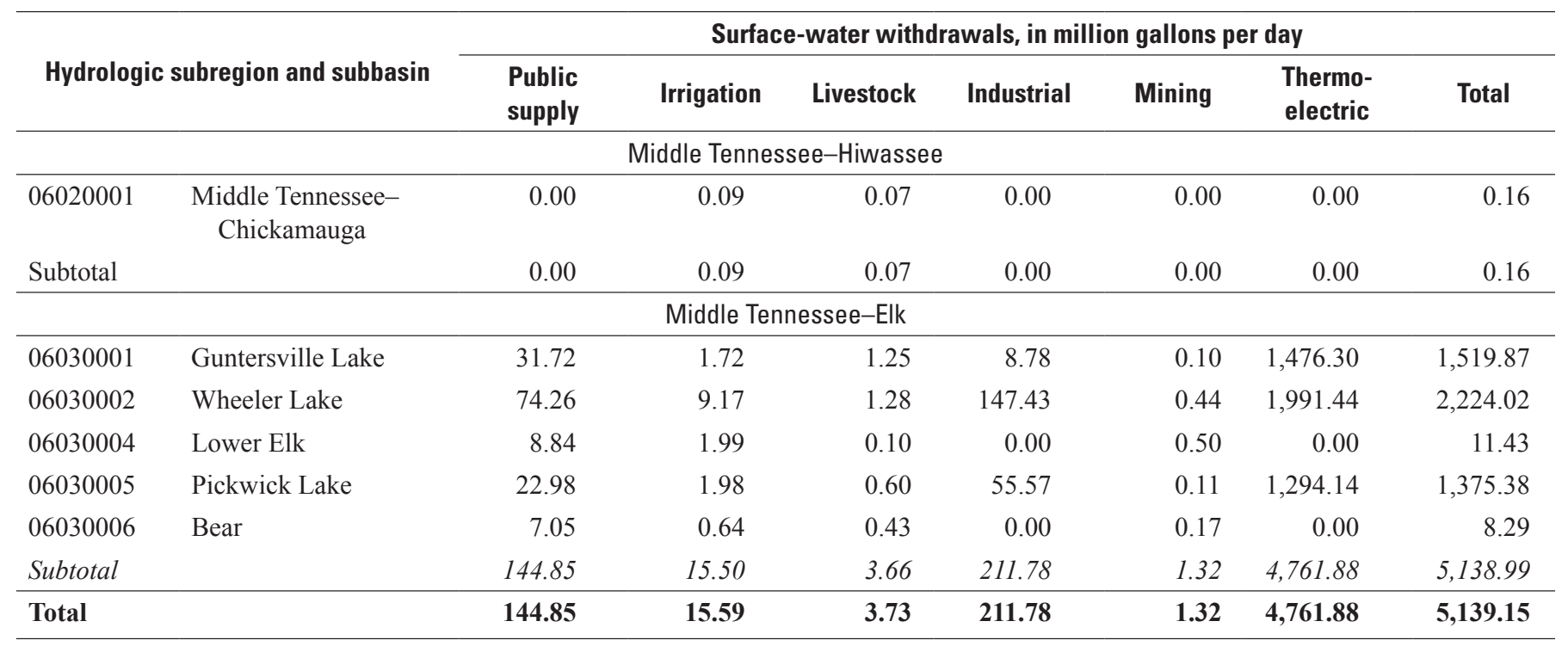


Table 9. Total groundwater withdrawals by category of use and county in the Tennessee River watershed within Alabama, 2005.

[Figures may not sum to totals because of independent rounding. County names in bold type indicate counties entirely contained within the watershed]

\begin{tabular}{|c|c|c|c|c|c|c|c|}
\hline \multirow{2}{*}{ County } & \multicolumn{7}{|c|}{ Groundwater withdrawals, in million gallons per day } \\
\hline & Public supply & Residential & Irrigation & Livestock & Industrial & Mining & Total \\
\hline Blount & 0.00 & 0.10 & 0.01 & 0.02 & 0.00 & 0.04 & 0.17 \\
\hline Colbert & 1.29 & 0.31 & 0.94 & 0.13 & 0.87 & 0.00 & 3.54 \\
\hline Cullman & 0.00 & 0.28 & 0.06 & 0.06 & 0.00 & 0.00 & 0.40 \\
\hline De Kalb & 0.70 & 0.87 & 0.50 & 0.58 & 0.00 & 0.00 & 2.65 \\
\hline Etowah & 0.00 & 0.23 & 0.00 & 0.01 & 0.00 & 0.00 & 0.24 \\
\hline Franklin & 0.82 & 0.31 & 0.25 & 0.30 & 0.00 & 0.39 & 2.07 \\
\hline Jackson & 0.63 & 0.91 & 0.04 & 0.32 & 0.00 & 0.07 & 1.97 \\
\hline Lauderdale & 1.40 & 1.30 & 0.74 & 0.20 & 0.00 & 0.00 & 3.64 \\
\hline Lawrence & 0.00 & 0.47 & 0.31 & 0.27 & 0.00 & 0.16 & 1.21 \\
\hline Limestone & 2.67 & 1.05 & 2.10 & 0.19 & 0.00 & 0.00 & 6.01 \\
\hline Madison & 25.59 & 1.12 & 1.61 & 0.14 & 0.00 & 0.48 & 28.94 \\
\hline Marion & 0.00 & 0.11 & 0.00 & 0.02 & 0.00 & 0.00 & 0.13 \\
\hline Marshall & 2.98 & 0.29 & 0.00 & 0.51 & 0.04 & 0.19 & 4.01 \\
\hline Morgan & 0.00 & 0.30 & 0.12 & 0.33 & 1.29 & 0.37 & 2.41 \\
\hline Winston & 0.00 & 0.14 & 0.00 & 0.01 & 0.00 & 0.00 & 0.15 \\
\hline Total & 36.08 & 7.78 & 6.68 & 3.09 & 2.20 & 1.70 & $\mathbf{5 7 . 5 4}$ \\
\hline
\end{tabular}

Table 10. Total groundwater withdrawals by category of use and hydrologic subregion and subbasin in the Tennessee River watershed within Alabama, 2005.

[Figures may not sum to totals because of independent rounding]

\begin{tabular}{|c|c|c|c|c|c|c|c|}
\hline \multirow{2}{*}{\multicolumn{2}{|c|}{ Hydrologic subregion and subbasin }} & \multicolumn{5}{|c|}{ Groundwater withdrawals, in million gallons per day } & \multirow{3}{*}{ Total } \\
\hline & & $\begin{array}{l}\text { Public } \\
\text { supply }\end{array}$ & Irrigation & Livestock & Industrial & Mining & \\
\hline \multicolumn{7}{|c|}{ Middle Tennessee-Hiwassee } & \\
\hline 06020001 & Middle Tennessee-Chickamauga & 0.66 & 0.05 & 0.06 & 0.00 & 0.00 & 0.77 \\
\hline Subtotal & & 0.66 & 0.05 & 0.06 & 0.00 & 0.00 & 0.77 \\
\hline \multicolumn{8}{|c|}{ Middle Tennessee-Elk } \\
\hline 06030001 & Guntersville Lake & 3.66 & 0.50 & 1.12 & 0.04 & 0.26 & 5.58 \\
\hline 06030002 & Wheeler Lake & 28.87 & 3.45 & 1.06 & 1.29 & 0.95 & 35.62 \\
\hline 06030004 & Lower Elk & 0.00 & 0.73 & 0.08 & 0.00 & 0.00 & 0.81 \\
\hline 06030005 & Pickwick Lake & 2.09 & 1.44 & 0.44 & 0.87 & 0.15 & 4.99 \\
\hline 06030006 & Bear & 0.82 & 0.53 & 0.32 & 0.00 & 0.34 & 2.01 \\
\hline Subtotal & & 35.44 & 6.65 & 3.02 & 2.20 & 1.70 & 49.01 \\
\hline Total & & 36.10 & 6.70 & 3.08 & 2.20 & 1.70 & 49.78 \\
\hline
\end{tabular}




\section{Public Supply}

Public supply refers to water that is withdrawn, treated, and distributed by public suppliers. Public suppliers provide water for a variety of uses, such as residential, commercial, industrial, thermoelectric-power, and public-water use. Thermoelectric power deliveries, industrial/commercial deliveries, and public uses and losses were not estimated separately but are included in the total public-supply withdrawals in this report.

Public-supply data are listed by county in table 11 and by hydrologic subbasin in table 12 . For 2005, public-supply withdrawals in the Tennessee River watershed in Alabama were $181 \mathrm{Mgal} / \mathrm{d}$. Public-supply withdrawals were 3.5 percent of total withdrawals and about 42 percent of total withdrawals for all categories excluding thermoelectric power (table 5). The majority of the public-supply water (145 Mgal/d, or 80 percent) was withdrawn from surface-water sources (fig. 10). The remaining $36 \mathrm{Mgal} / \mathrm{d}$, or 20 percent, was withdrawn from wells and springs. In 2005, about 765,000 people, or 89 percent of the population, depended on water from public suppliers.

The geographic distributions of the total, groundwater, and surface-water withdrawals for public supply by county are shown in figure 11. Madison County, which encompasses the city of Huntsville, had the largest amount of withdrawal, accounting for about 36 percent of the publicsupply withdrawals in the Tennessee River Valley in Alabama (figs. 11 and 12, table 11). Public suppliers in Colbert, Madison, Marshall, and Morgan Counties collectively served more than 90 percent of their respective county populations (table 11). The largest surface-water withdrawals occurred in Madison and Morgan Counties (39 and $30 \mathrm{Mgal} / \mathrm{d}$, respectively), and the largest groundwater withdrawals occurred in Madison County (26 Mgal/d).

Table 11. Public-supply population served, withdrawals, per capita use, return flows, and consumption by county in the Tennessee River watershed in Alabama, 2005.

[Figures may not sum to totals because of independent rounding. County names in bold type indicate counties entirely contained within the Tennessee River Watershed]

\begin{tabular}{|c|c|c|c|c|c|c|c|c|c|}
\hline County & Population & \multicolumn{2}{|c|}{$\begin{array}{c}\text { Population } \\
\text { served by } \\
\text { public supply }\end{array}$} & \multicolumn{3}{|c|}{$\begin{array}{l}\text { Withdrawals by source, } \\
\text { in million gallons per day }\end{array}$} & $\begin{array}{l}\text { Gross public } \\
\text { supply per } \\
\text { capita use, in } \\
\text { gallons per day }\end{array}$ & $\begin{array}{l}\text { Return flow, } \\
\text { in million } \\
\text { gallons } \\
\text { per day }\end{array}$ & $\begin{array}{c}\text { Consumption } \\
\text { in million } \\
\text { gallons } \\
\text { per day }\end{array}$ \\
\hline Blount & 1,600 & $0^{1}$ & 0 & 0.00 & 0.00 & 0.00 & - & 0.00 & 0.00 \\
\hline De Kalb & 40,330 & 29,346 & 73 & 0.70 & 0.47 & 1.17 & 40 & 0.00 & 1.17 \\
\hline Etowah & 2,840 & $0^{1}$ & 0 & 0.00 & 0.00 & 0.00 & - & 0.00 & 0.00 \\
\hline Franklin & 28,458 & 22,450 & 79 & 0.82 & 3.88 & 4.7 & 209 & 3.71 & 0.99 \\
\hline Jackson & 53,650 & 39,924 & 74 & 0.63 & 10.08 & 10.71 & 268 & 5.24 & 5.47 \\
\hline Madison & 298,192 & 288,901 & 97 & 25.59 & 38.85 & 64.44 & 223 & 36.27 & 28.17 \\
\hline Marion & 3,473 & 2,357 & 68 & 0.00 & 3.17 & 3.17 & 1,345 & 0.12 & 3.05 \\
\hline Marshall & 63,989 & 59,832 & 94 & 2.98 & 21.16 & 24.14 & 403 & 10.30 & 13.84 \\
\hline Morgan & 113,510 & 109,690 & 97 & 0.00 & 30.42 & 30.42 & 277 & 21.79 & 8.63 \\
\hline Winston & 2,641 & $0^{1}$ & 0 & 0.00 & 0.00 & 0.00 & - & 0.00 & 0.00 \\
\hline Total & $\mathbf{8 5 8 , 0 9 7}$ & 764,468 & 89 & 36.08 & 144.85 & 180.93 & 237 & 98.87 & 82.06 \\
\hline
\end{tabular}

\footnotetext{
${ }^{1}$ No public water-supply withdrawals were reported in the portion of this county within the Tennessee River watershed in 2005 . All estimated population for this area was assumed to be self-supplied. Distribution areas of local public water supplies were not determined for this study, and there may be some error in the assumption that the entire population of these areas is self-supplied.
} 
Table 12. Public-supply water use by hydrologic subregion and subbasin in the Tennessee River watershed within Alabama, 2005.

[Figures may not sum to totals because of independent rounding]

\begin{tabular}{|c|c|c|c|c|c|c|c|}
\hline \multirow{2}{*}{\multicolumn{2}{|c|}{$\begin{array}{l}\text { Hydrologic subregion } \\
\text { and subbasin }\end{array}$}} & \multirow[t]{2}{*}{$\begin{array}{c}\text { Total } \\
\text { population }\end{array}$} & \multicolumn{3}{|c|}{$\begin{array}{l}\text { Withdrawals by source, } \\
\text { in million gallons per day }\end{array}$} & \multirow{2}{*}{$\begin{array}{c}\text { Return flow, } \\
\text { in million } \\
\text { gallons per } \\
\text { day }\end{array}$} & \multirow{2}{*}{$\begin{array}{c}\text { Consumption, in } \\
\text { million gallons } \\
\text { per day }\end{array}$} \\
\hline & & & Groundwater & Surface water & Total & & \\
\hline \multicolumn{8}{|c|}{ Middle Tennessee-Hiwassee } \\
\hline 06020001 & $\begin{array}{l}\text { Middle Tennessee-- } \\
\text { Chickamauga }\end{array}$ & 2,519 & 0.66 & 0.00 & 0.66 & 0.00 & 0.66 \\
\hline Subtotal & & 2,519 & 0.66 & 0.00 & 0.66 & 0.00 & 0.66 \\
\hline \multicolumn{8}{|c|}{ Middle Tennessee-Elk } \\
\hline 06030001 & Guntersville Lake & 137,739 & 3.66 & 31.72 & 35.38 & 14.69 & 20.69 \\
\hline 06030002 & Wheeler Lake & 517,460 & 28.87 & 74.26 & 103.13 & 65.30 & 37.83 \\
\hline 06030004 & Lower Elk & 15,440 & 0.00 & 8.84 & 8.84 & 0.11 & 8.73 \\
\hline 06030005 & Pickwick Lake & 152,409 & 2.09 & 22.98 & 25.07 & 14.96 & 10.11 \\
\hline 06030006 & Bear & 32,530 & 0.82 & 7.05 & 7.87 & 3.83 & 4.04 \\
\hline Subtotal & & 855,578 & 35.44 & 144.85 & 180.29 & 98.89 & 81.40 \\
\hline Total & & 858,097 & 36.10 & 144.85 & 180.95 & 98.89 & 82.06 \\
\hline
\end{tabular}

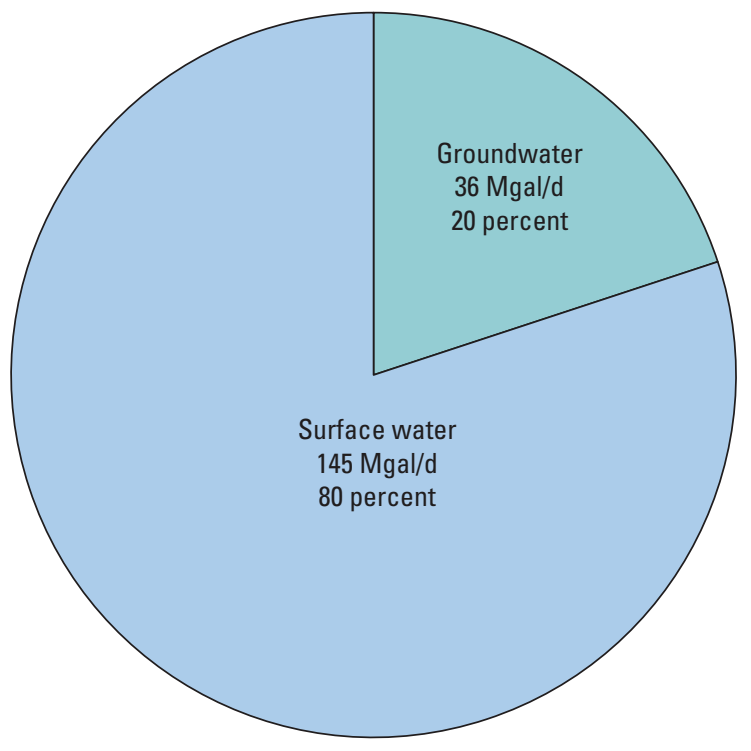

Figure 10. Source of public-supply water withdrawals in the Tennessee River watershed in Alabama, 2005. 

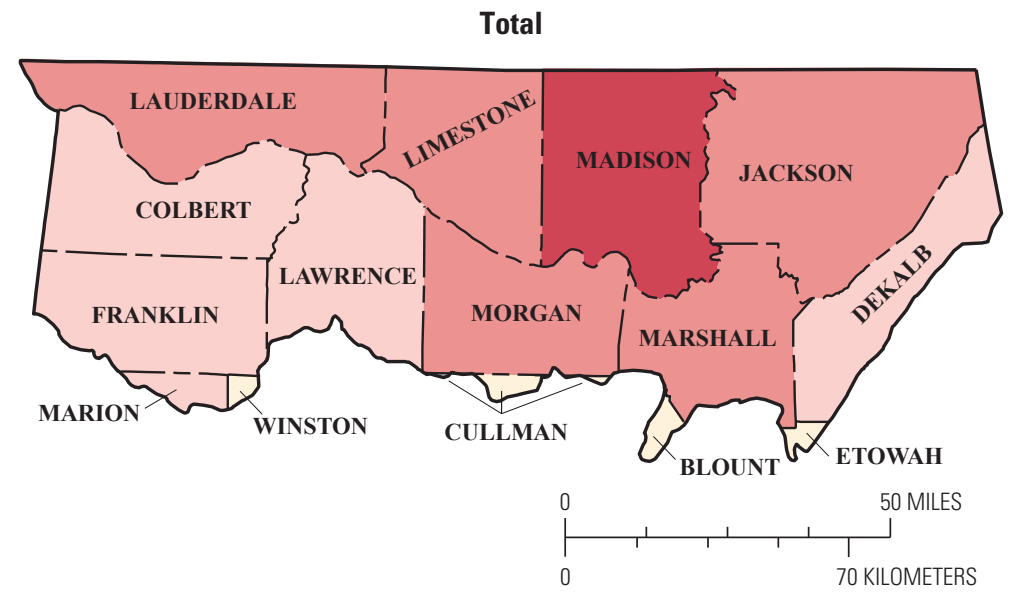

(ิ)

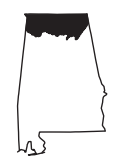

Location of the Tennessee River watershed in Alabama

\section{EXPLANATION}

Public-supply withdrawals by county, in million gallons per day

0

0.01 to 9.99

10 to 49.99

50 to 100
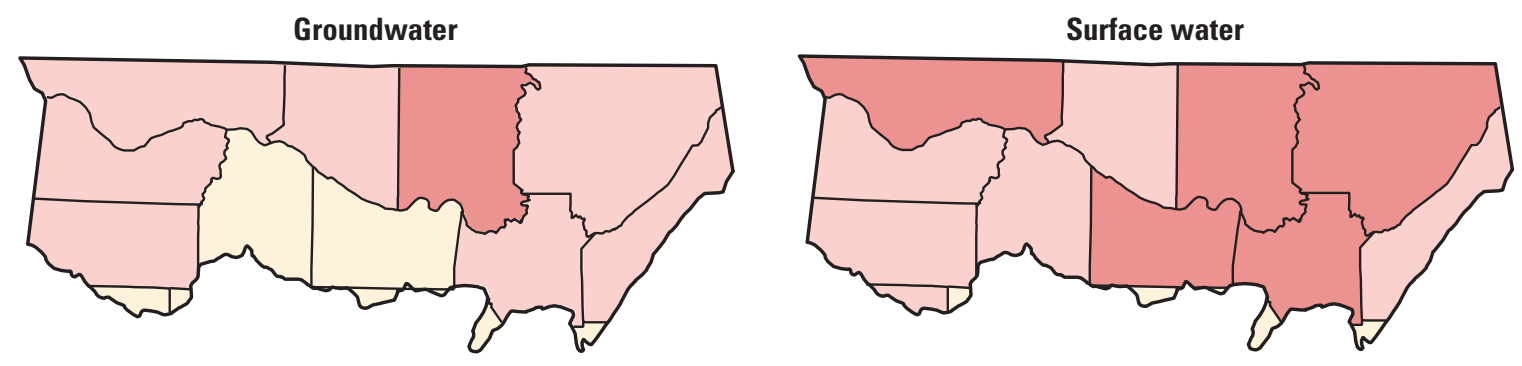

Figure 11. Public-supply freshwater withdrawals by source and county in the Tennessee River watershed in Alabama, 2005.
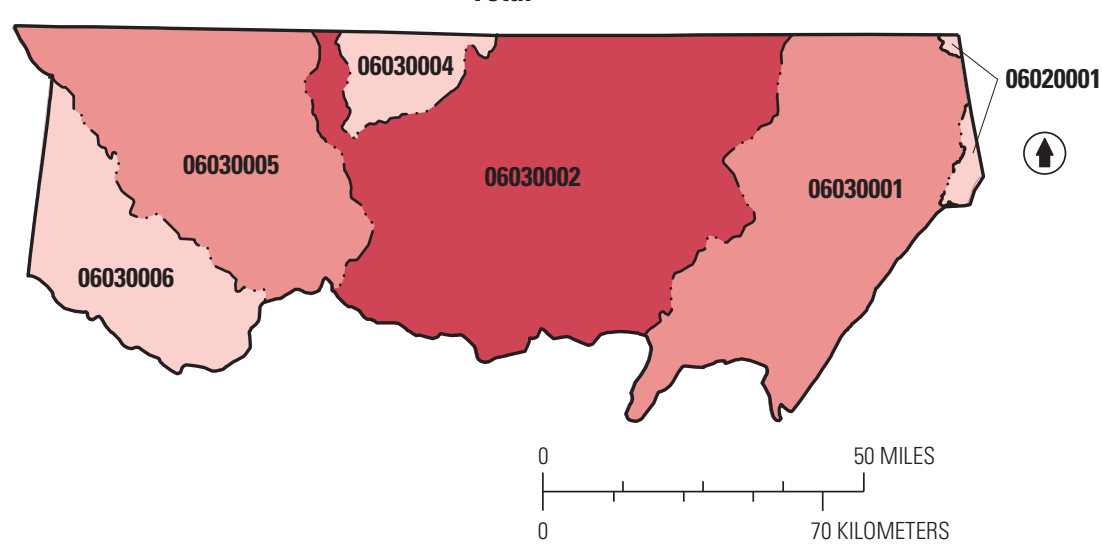

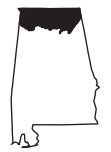

Location of the Tennessee River watershed in Alabama

\section{EXPLANATION}

Public-supply withdrawals by subbasin, in million gallons per day

0 0.01 to 9.99 10 to 49.99 50 to 105
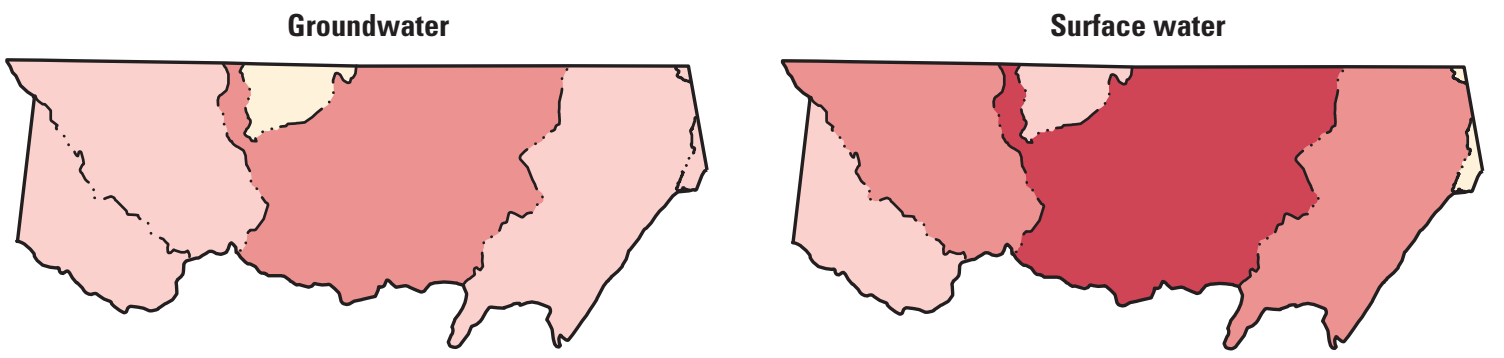

Figure 12. Public-supply freshwater withdrawals by source and subbasin in the Tennessee River watershed in Alabama, 2005. 


\section{Residential}

Residential water refers to the water that is used for all indoor household purposes, such as drinking, preparing food, bathing, washing clothes and dishes, and flushing toilets, and outdoor purposes, such as watering lawns and gardens and pool maintenance. Residential water use is defined in this report as public-supplied residential deliveries plus selfsupplied residential withdrawals. Residential water use in the Tennessee River watershed totaled $75 \mathrm{Mgal} / \mathrm{d}$ in 2005 (table 13). Public suppliers delivered 90 percent, or $67 \mathrm{Mgal} / \mathrm{d}$, of residential water, while the remaining 10 percent, or $8 \mathrm{Mgal} / \mathrm{d}$, of residential water was self-supplied from private groundwater wells. Self-supplied residential withdrawals were less than 1 percent of the total water withdrawals and about 2 percent of the withdrawals for all categories except thermoelectric power (table 5). About 11 percent of the population (or 93,629 people) relied on private wells for their drinking-water needs in 2005 (table 13).

The geographic distributions of groundwater withdrawals for self-supplied residential use, self-supplied residential population as a percentage of the total Tennessee River watershed population, and self-supplied residential population by county are shown in figures 13 and 14. The largest aggregated self-supplied residential withdrawals were in Lauderdale (1.30 Mgal/d) and Madison (1.12 Mgal/d) Counties (table 13). These two counties represented about 31 percent of the total self-supplied residential withdrawals and 25 percent of the self-supplied residential population.

Table 13. Residential water users, water use, and per capita use by county in the Tennessee River watershed within Alabama, 2005.

[Figures may not sum to totals because of independent rounding. County names in bold type indicate counties entirely contained within the watershed]

\begin{tabular}{|c|c|c|c|c|c|c|c|c|c|}
\hline \multirow[b]{2}{*}{ County } & \multicolumn{3}{|c|}{ Population } & \multicolumn{3}{|c|}{$\begin{array}{c}\text { Residential water use, } \\
\text { in million gallons per day }\end{array}$} & \multicolumn{3}{|c|}{$\begin{array}{l}\text { Residential per capita use, } \\
\text { in gallons per day }\end{array}$} \\
\hline & Total & $\begin{array}{c}\text { Served by } \\
\text { public } \\
\text { supply }\end{array}$ & $\begin{array}{c}\text { Self- } \\
\text { supplied }\end{array}$ & Withdrawals & Deliveries & Total & Self-supplied ${ }^{1}$ & $\begin{array}{l}\text { Public- } \\
\text { supplied }\end{array}$ & Combined \\
\hline Blount & 1,600 & $0^{2}$ & 1,600 & 0.10 & 0.00 & 0.10 & 62 & $-^{3}$ & 62 \\
\hline Colbert & 54,660 & 50,704 & 3,956 & 0.31 & 3.31 & 3.61 & 77 & 65 & 66 \\
\hline DeKalb & 40,330 & 29,346 & 10,984 & 0.87 & 2.96 & 3.83 & 79 & 101 & 95 \\
\hline Etowah & 2,840 & $0^{2}$ & 2,840 & 0.23 & 0.00 & 0.23 & 82 & -3 & 82 \\
\hline Franklin & 28,458 & 22,450 & 6,008 & 0.31 & 1.43 & 1.74 & 51 & 64 & 61 \\
\hline Jackson & 53,650 & 39,924 & 13,726 & 0.91 & 2.69 & 3.60 & 67 & 67 & 67 \\
\hline Madison & 298,192 & 288,901 & 9,291 & 1.12 & 30.91 & 32.03 & 121 & 107 & 107 \\
\hline Marion & 3,473 & 2,357 & 1,116 & 0.11 & 0.20 & 0.31 & 95 & 84 & 88 \\
\hline Marshall & 63,989 & 59,832 & 4,157 & 0.29 & 4.02 & 4.31 & 69 & 67 & 67 \\
\hline Morgan & 113,510 & 109,690 & 3,820 & 0.30 & 9.07 & 9.38 & 79 & 83 & 83 \\
\hline Winston & 2,641 & $0^{2}$ & 2,641 & 0.14 & 0.00 & 0.14 & 51 & $-^{3}$ & 51 \\
\hline \multirow{3}{*}{$\begin{array}{l}\text { Total } \\
\text { Percent } \\
\text { Average }\end{array}$} & $\mathbf{8 5 8 , 0 9 7}$ & 764,468 & 93,629 & 7.78 & 67.11 & 74.89 & & & \\
\hline & & 89 & 11 & & & & & & \\
\hline & & & & & & & 80 & 79 & 77 \\
\hline
\end{tabular}

${ }^{1}$ Per capita use was calculated by dividing total withdrawals by the self-supplied population.

${ }^{2}$ No public water-supply withdrawals were reported in the portion of this county within the Tennessee River watershed in 2005 . All estimated population for this area was assumed to be self-supplied. Distribution areas of local public water supplies were not determined for this study, and there may be some error in the assumption that the entire population of these areas is self-supplied.

${ }^{3}$ Public-supplied residential per capita use was not estimated because no public water-supply withdrawals were reported in the portion of the county located within the Tennessee River watershed. 


\section{Total (groundwater)}
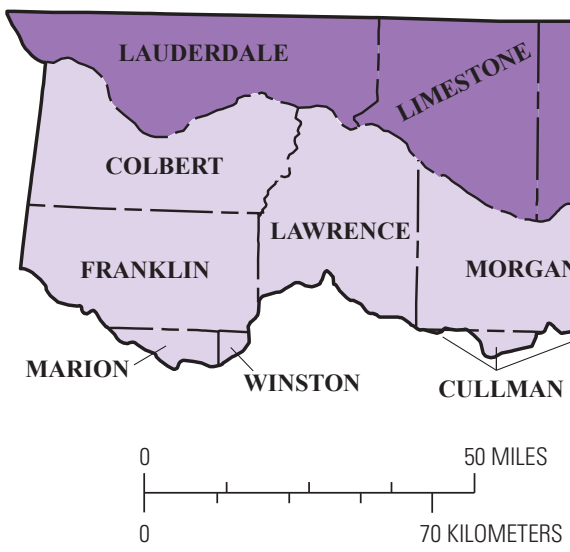
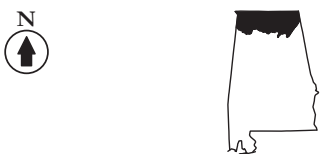

Location of the Tennessee River watershed in Alabama

\section{EXPLANATION}

Self-supplied residential groundwater withdrawals by county, in million gallons per day

BLOUNT ETOWAH

0.5 to 0.99

1 to 1.5

Figure 13. Self-supplied residential groundwater withdrawals by county in the Tennessee River watershed in Alabama, 2005.
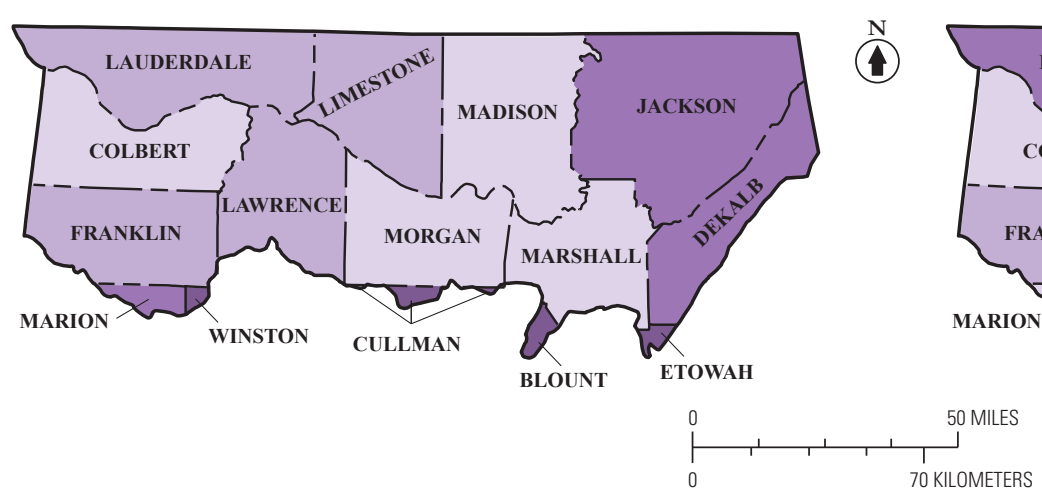

EXPLANATION

Percentage of self-supplied population, by county
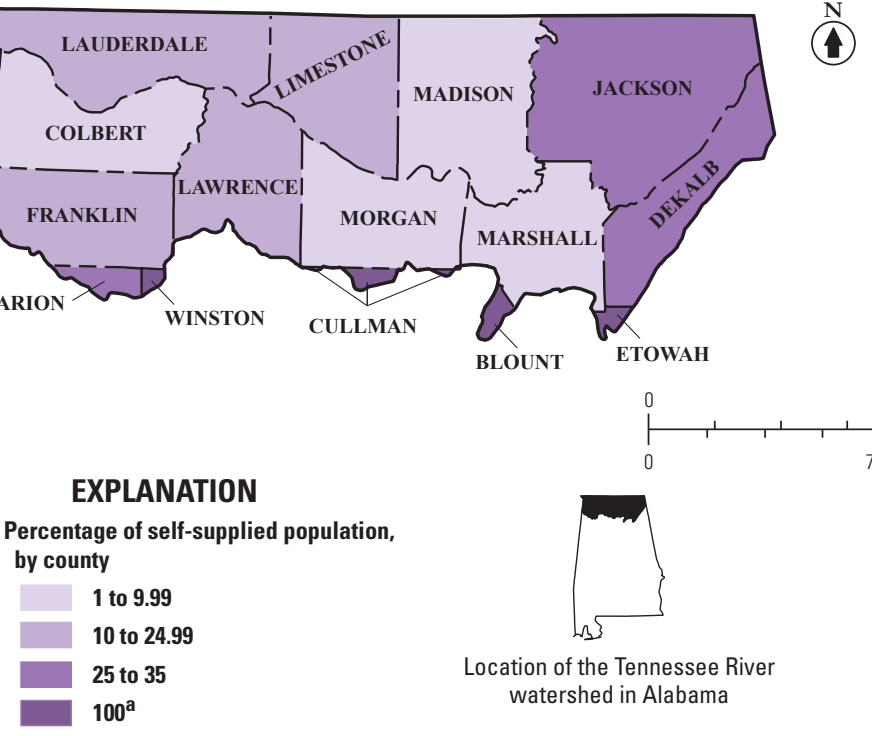
50 MILES

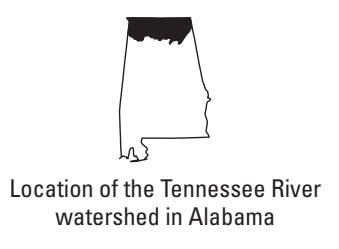

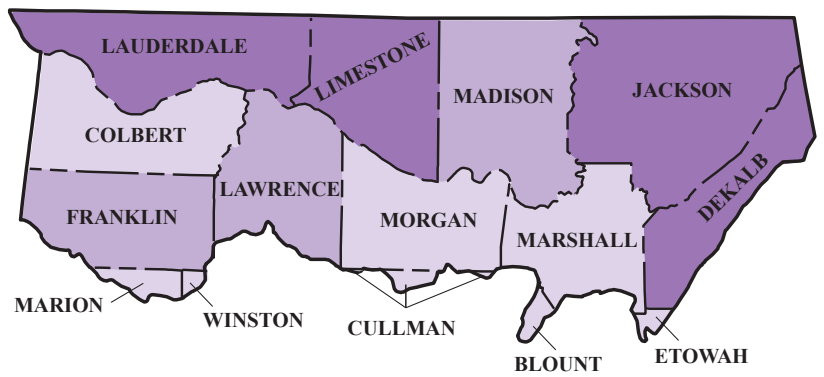

\section{EXPLANATION}

Self-supplied population, by county

1,000 to 4,999

5,000 to 9,999

10,000 to 15,000

Figure 14. Self-supplied residential population as a percentage of total population and self-supplied residential population by county in the Tennessee River watershed in Alabama, 2005.

The average residential per capita use in the study area-public-supplied residential deliveries plus self-supplied residential withdrawals divided by the total population - was $77 \mathrm{gal} / \mathrm{d}$ (table 13). The average public-supplied residential per capita use in the study area-public-supplied residential deliveries divided by population served - was $79 \mathrm{gal} / \mathrm{d}$ and ranged from $64 \mathrm{gal} / \mathrm{d}$ for Franklin County to $107 \mathrm{gal} / \mathrm{d}$ for Madison County. Public-supplied residential per capita use was not calculated for the portions of Blount, Cullman, Etowah, and Winston Counties in the Tennessee River watershed because no public suppliers were known to be located in those areas. Instead, all populations in those partial counties were assumed to be self-supplied. The average self-supplied residential per capita use in the study area - self-supplied residential withdrawals divided by self-supplied residential population - was $80 \mathrm{gal} / \mathrm{d}$.

The sources of information and methodology for estimating public-supply residential deliveries, population served by public suppliers, self-supplied residential withdrawals, and self-supplied population are detailed in the "Public-Supply and Residential Water Use" and "Population Served and Self-Supplied Residential Population" sections in the "Data Compilation, Sources of Data, and Methodology" section of this report. 


\section{Irrigation}

Irrigation water refers to water that is applied by an irrigation system to assist in the growing of crops and pastures or to maintain vegetative growth in recreational lands such as parks and golf courses. Irrigation includes water that is applied for pre-irrigation, frost protection, chemical application, weed control, field preparation, crop cooling, harvesting, dust suppression, and the leaching of salts from the root zone and water that is lost in conveyance. Conveyance loss was not reported for 2005. Although annual water-use data are expressed in terms of million gallons per day, irrigation water is applied, generally, only during part of each year and at variable rates; therefore, the actual rate of application during the growing season would be more than the daily rate expressed as million gallons per day.
Irrigation withdrawals and irrigated acreage by county and subbasin are listed in tables 14 and 15, respectively. For 2005, total irrigation withdrawals for the Tennessee River watershed in Alabama were $22 \mathrm{Mgal} / \mathrm{d}$. Irrigation withdrawals were less than 1 percent of total withdrawals and about 5 percent of total withdrawals for all categories excluding thermoelectric power (table 5). Of the total irrigation withdrawals, 70 percent, or $16 \mathrm{Mgal} / \mathrm{d}$, was from surface water, and the remaining 30 percent, or $7 \mathrm{Mgal} / \mathrm{d}$, was from groundwater (table 14; fig. 15). Consumptive use of all irrigation withdrawals is estimated to be 100 percent in 2005. Acres of irrigated land in partial counties and the total irrigation water withdrawn by county were calculated by multiplying amounts for entire counties by the percentage of the county within the Tennessee River watershed.

Table 14. Irrigation water use by county in the Tennessee River watershed in Alabama, 2005.

[Figures may not sum to totals because of independent rounding. County names in bold type indicate counties entirely contained within the watershed]

\begin{tabular}{|c|c|c|c|c|c|c|}
\hline \multirow{2}{*}{ County } & \multirow{2}{*}{$\begin{array}{l}\text { Estimated irrigated } \\
\text { acreage within the } \\
\text { Tennessee River } \\
\text { watershed, in } \\
\text { thousand acres }\end{array}$} & \multicolumn{3}{|c|}{ Withdrawals, in million gallons per day } & \multirow{2}{*}{$\begin{array}{l}\text { Return flow, } \\
\text { in million } \\
\text { gallons per day }\end{array}$} & \multirow{2}{*}{$\begin{array}{c}\begin{array}{c}\text { Consumption, } \\
\text { in million }\end{array} \\
\text { gallons per day } \\
\text { Net water demand }\end{array}$} \\
\hline & & Groundwater & Surface water & Total & & \\
\hline Blount & 0.02 & 0.01 & 0.02 & 0.03 & 0.00 & 0.03 \\
\hline Colbert & 2.64 & 0.94 & 1.40 & 2.34 & 0.00 & 2.34 \\
\hline Cullman & 0.04 & 0.06 & 0.01 & 0.07 & 0.00 & 0.07 \\
\hline DeKalb & 0.74 & 0.50 & 0.88 & 1.38 & 0.00 & 1.38 \\
\hline Etowah & 0.05 & 0.00 & 0.04 & 0.04 & 0.00 & 0.04 \\
\hline Franklin & 0.51 & 0.25 & 0.20 & 0.45 & 0.00 & 0.45 \\
\hline Jackson & 0.95 & 0.04 & 0.67 & 0.71 & 0.00 & 0.71 \\
\hline Lauderdale & 1.16 & 0.74 & 0.43 & 1.17 & 0.00 & 1.17 \\
\hline Lawrence & 1.97 & 0.31 & 1.18 & 1.49 & 0.00 & 1.49 \\
\hline Limestone & 8.74 & 2.10 & 6.16 & 8.26 & 0.00 & 8.26 \\
\hline Madison & 5.56 & 1.61 & 3.30 & 4.91 & 0.00 & 4.91 \\
\hline Marion & 0.01 & 0.00 & 0.01 & 0.01 & 0.00 & 0.01 \\
\hline Marshall & 1.08 & 0.00 & 0.57 & 0.57 & 0.00 & 0.57 \\
\hline Morgan & 1.39 & 0.12 & 0.74 & 0.86 & 0.00 & 0.86 \\
\hline Winston & 0.00 & 0.00 & 0.00 & 0.00 & 0.00 & 0.00 \\
\hline Total & 24.87 & 6.68 & 15.61 & 22.29 & 0.00 & 22.29 \\
\hline
\end{tabular}


Table 15. Irrigation water use by hydrologic subregion and subbasin in the Tennessee River watershed within Alabama, 2005.

[Figures may not sum to totals because of independent rounding]

\begin{tabular}{|c|c|c|c|c|c|c|}
\hline \multirow{2}{*}{\multicolumn{2}{|c|}{ Hydrologic subregion and subbasin }} & \multicolumn{3}{|c|}{ Withdrawals, in million gallons per day } & \multirow{2}{*}{$\begin{array}{c}\text { Return flow, } \\
\text { in million gallons } \\
\text { per day }\end{array}$} & \multirow{2}{*}{$\begin{array}{c}\text { Consumption, in millior } \\
\text { gallons per day } \\
\text { Net water demand } \\
\end{array}$} \\
\hline & & Groundwater & Surface water & Total & & \\
\hline \multicolumn{7}{|c|}{ Middle Tennessee-Hiwassee } \\
\hline 06020001 & $\begin{array}{l}\text { Middle Tennessee- } \\
\text { Chickamauga }\end{array}$ & 0.05 & 0.09 & 0.14 & 0.00 & 0.14 \\
\hline Subtotal & & 0.05 & 0.09 & 0.14 & 0.00 & 0.14 \\
\hline \multicolumn{7}{|c|}{ Middle Tennessee-Elk } \\
\hline 06030001 & Guntersville Lake & 0.50 & 1.72 & 2.22 & 0.00 & 2.22 \\
\hline 06030002 & Wheeler Lake & 3.45 & 9.17 & 12.62 & 0.00 & 12.62 \\
\hline 06030004 & Lower Elk & 0.73 & 1.99 & 2.72 & 0.00 & 2.72 \\
\hline 06030005 & Pickwick Lake & 1.44 & 1.98 & 3.42 & 0.00 & 3.42 \\
\hline 06030006 & Bear & 0.53 & 0.64 & 1.17 & 0.00 & 1.17 \\
\hline Subtotal & & 6.65 & 15.50 & 22.15 & 0.00 & 22.15 \\
\hline Total & & 6.70 & 15.59 & 22.29 & 0.00 & 22.29 \\
\hline
\end{tabular}

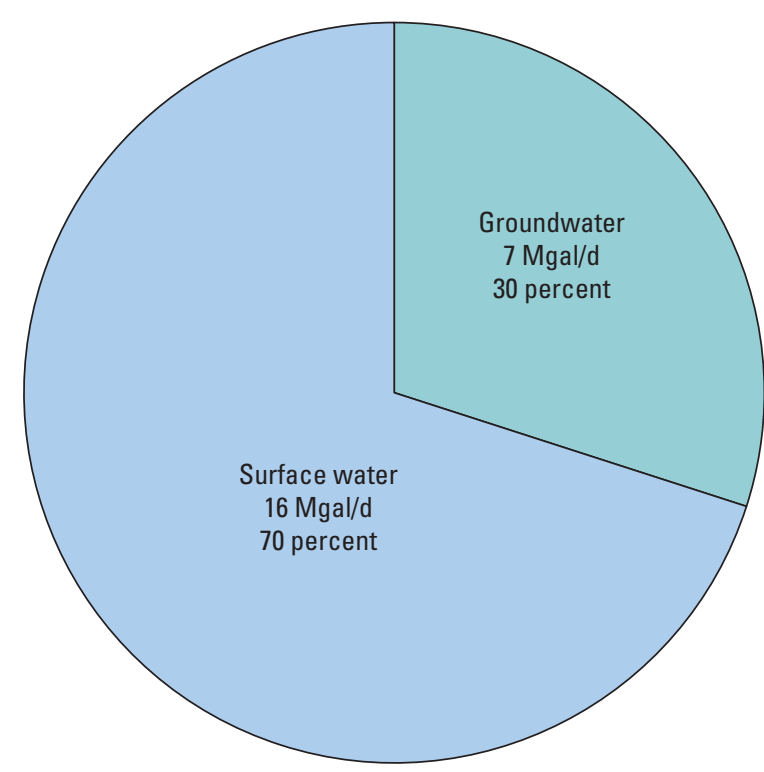

Figure 15. Source of water for irrigation use in the Tennessee River Watershed in Alabama, 2005. (Mgal/d, million gallons per day)
The geographic distributions of total, groundwater, and surface-water withdrawals for irrigation by county and by hydrologic subbasin are shown in figures 16 and 17, respectively. Nine of the 15 counties withdrew less than $1 \mathrm{Mgal} / \mathrm{d}$ each for irrigation. Limestone County withdrew 37 percent $(8 \mathrm{Mgal} / \mathrm{d})$ of the irrigation water (table 14). Six counties (Colbert, DeKalb, Lauderdale, Lawrence, Limestone, and Madison) each had withdrawals of more than $1 \mathrm{Mgal} / \mathrm{d}$, for a total withdrawal of $20 \mathrm{Mgal} / \mathrm{d}$ or nearly 88 percent of the irrigation total for the Tennessee River watershed in Alabama. The Wheeler Lake subbasin (HUC 06030002, in the Middle Tennessee-Elk subregion) had the greatest withdrawal for irrigation, $13 \mathrm{Mgal} / \mathrm{d}$, which is about 57 percent of the total withdrawals for irrigation (table 15). 
Total
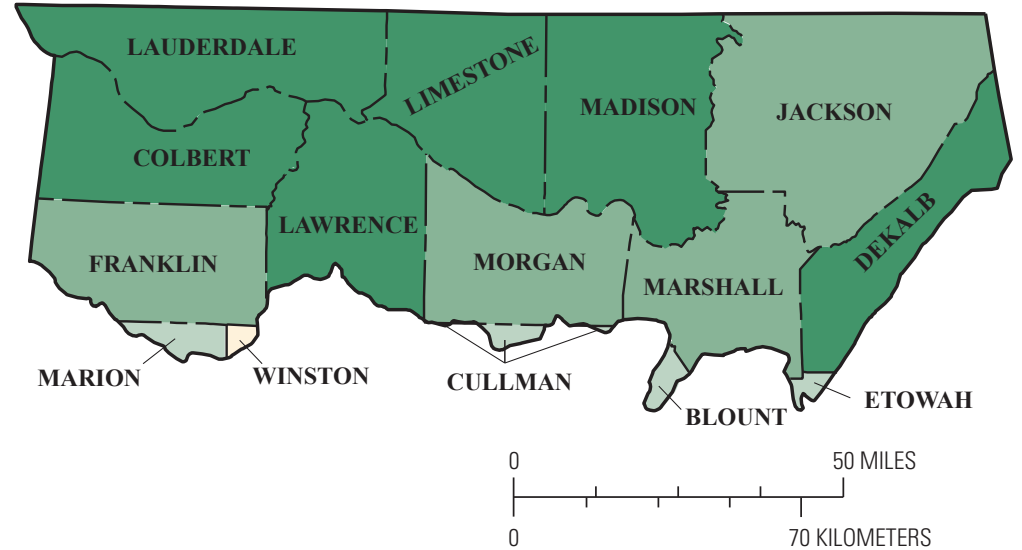

(1)

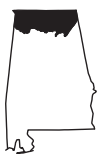

Location of the Tennessee River watershed in Alabama

\section{EXPLANATION}

Irrigation withdrawals by county, in million gallons per day

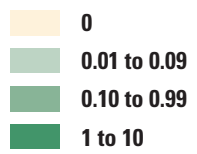

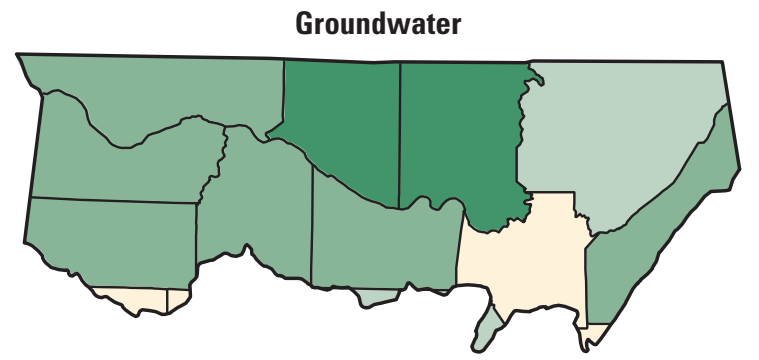

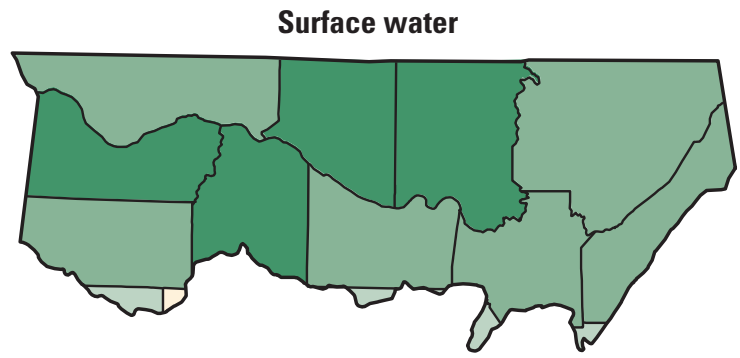

Figure 16. Irrigation withdrawals by source and county in the Tennessee River watershed in Alabama, 2005.

Total
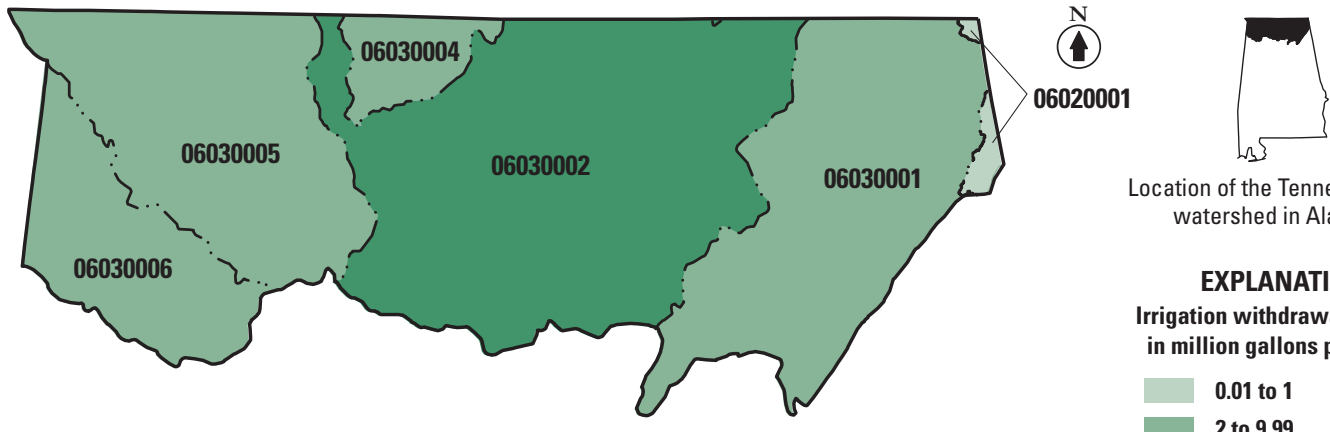

Location of the Tennessee River watershed in Alabama

\section{EXPLANATION}

Irrigation withdrawals by subbasin,

in million gallons per day

\subsection{1 to 1}

2 to 9.99

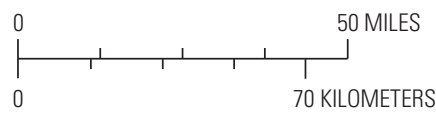

10 to 20

\section{Groundwater}

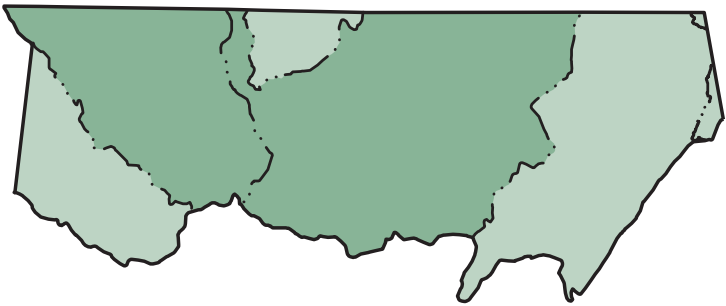

Surface water

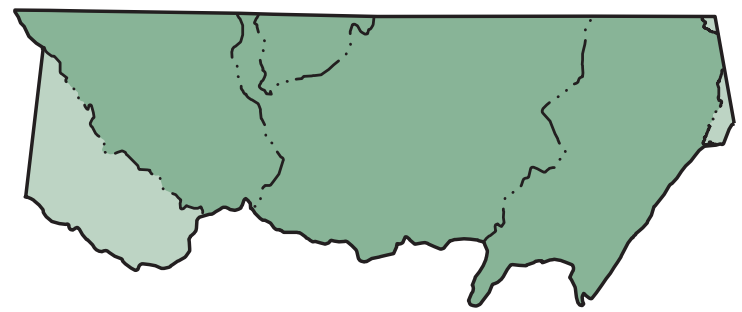

Figure 17. Irrigation withdrawals by source and subbasin in the Tennessee River watershed in Alabama, 2005. 


\section{Livestock}

Livestock water use is associated with livestock watering, feedlots, dairy operations, and other on-farm needs. Water consumed by cooling of the facilities for the animals and products, dairy sanitation and cleaning of facilities, animal wastedisposal systems, and incidental water loss during livestock care is included within the livestock water use category. The primary livestock types in Alabama include poultry, beef cattle and calves, dairy cows and heifers, hogs and pigs, and horses and ponies. The livestock category excludes on-farm residential use (residential category) and irrigation water use.

During 2005, withdrawals for livestock in the Tennessee River watershed in Alabama were $7 \mathrm{Mgal} / \mathrm{d}$ (tables 16 and 17). Surface water was the source for 55 percent ( $4 \mathrm{Mgal} / \mathrm{d}$ ) of the withdrawals, and groundwater was the source for the remaining 45 percent (3 Mgal/d) (fig. 18). Withdrawals of water for livestock use were less than 1 percent of total withdrawals and were nearly 2 percent of total withdrawals excluding thermoelectric power (table 5).
The geographic distributions of total, groundwater, and surface-water withdrawals for livestock by county and by hydrologic subbasin are shown in figures 19 and 20. The counties with large water withdrawals for livestock mostly corresponded to the areas of Alabama with major producers of poultry, cattle and calves, and hogs and pigs (U.S. Department of Agriculture, National Agricultural Statistics Service, 2006a). Blount, Cullman, DeKalb, and Marshall Counties, the top four broiler chicken producing counties in Alabama, accounted for about 35 percent of the total withdrawals for livestock (U.S. Department of Agriculture, National Agricultural Statistics Service, 2006b). The Guntersville Lake (2.4 $\mathrm{Mgal} / \mathrm{d})$, Wheeler Lake (2.3 Mgal/d), and Pickwick Lake (1 $\mathrm{Mgal} / \mathrm{d}$ ) subbasins accounted for 84 percent $(6 \mathrm{Mgal} / \mathrm{d})$ of the total withdrawals for livestock in the Tennessee River watershed in Alabama. These three subbasins also encompass the portions of Blount, Cullman, DeKalb, and Marshall Counties that are within the Tennessee River watershed.

Table 16. Water withdrawals for livestock by county in the Tennessee River watershed within Alabama, 2005.

[Figures may not sum to totals because of independent rounding. County names in bold type indicate counties entirely contained within the watershed]

\begin{tabular}{lcccc}
\hline \multirow{2}{*}{ County } & \multicolumn{2}{c}{ Withdrawals, in million gallons per day } & & $\begin{array}{c}\text { Consumption, in million } \\
\text { gallons per day }\end{array}$ \\
\cline { 2 - 3 } Blount & Groundwater & Surface water & Total & Net water demand \\
Colbert & 0.02 & 0.02 & 0.04 & 0.04 \\
Cullman & 0.13 & 0.17 & 0.30 & 0.30 \\
DeKalb & 0.06 & 0.06 & 0.12 & 0.12 \\
Etowah & 0.58 & 0.65 & 1.23 & 1.23 \\
Franklin & 0.01 & 0.01 & 0.02 & 0.02 \\
Jackson & 0.30 & 0.4 & 0.70 & 0.70 \\
Lauderdale & 0.32 & 0.4 & 0.72 & 0.72 \\
Lawrence & 0.20 & 0.28 & 0.48 & 0.48 \\
Limestone & 0.27 & 0.36 & 0.63 & 0.63 \\
Madison & 0.19 & 0.25 & 0.44 & 0.44 \\
Marion & 0.14 & 0.19 & 0.33 & 0.33 \\
Marshall & 0.02 & 0.02 & 0.04 & 0.04 \\
Morgan & 0.51 & 0.51 & 1.02 & 1.02 \\
Winston & 0.33 & 0.4 & 0.73 & 0.73 \\
\hline Total & 0.01 & 0.01 & 0.02 & 0.02 \\
\hline & $\mathbf{3 . 0 9}$ & $\mathbf{3 . 7 3}$ & $\mathbf{6 . 8 2}$ & $\mathbf{6 . 8 2}$ \\
\hline & & & & \\
\hline
\end{tabular}


Table 17. Water withdrawals for livestock by hydrologic subregion and subbasin in Tennessee River watershed within Alabama, 2005.

[Figures may not sum to totals because of independent rounding]

\begin{tabular}{|c|c|c|c|c|c|}
\hline \multirow{2}{*}{$\begin{array}{l}\text { Hydrologic subregion } \\
\text { and subbasin }\end{array}$} & & \multicolumn{3}{|c|}{ Withdrawals, in million gallons per day } & \multirow{2}{*}{$\begin{array}{c}\text { Consumption, in } \\
\text { million gallons } \\
\text { per day } \\
\begin{array}{c}\text { Net water } \\
\text { demand }\end{array}\end{array}$} \\
\hline & & Groundwater & Surface water & Total & \\
\hline \multicolumn{6}{|c|}{ Middle Tennessee-Hiwassee } \\
\hline 06020001 & $\begin{array}{l}\text { Middle Tennessee- } \\
\text { Chickamauga }\end{array}$ & 0.06 & 0.07 & 0.13 & 0.13 \\
\hline Subtotal & & 0.06 & 0.07 & 0.13 & 0.13 \\
\hline \multicolumn{6}{|c|}{ Middle Tennessee-Elk } \\
\hline 06030001 & Guntersville Lake & 1.12 & 1.25 & 2.37 & 2.37 \\
\hline 06030002 & Wheeler Lake & 1.06 & 1.28 & 2.34 & 2.34 \\
\hline 06030004 & Lower Elk & 0.08 & 0.10 & 0.18 & 0.18 \\
\hline 06030005 & Pickwick Lake & 0.44 & 0.60 & 1.04 & 1.04 \\
\hline 06030006 & Bear & 0.32 & 0.43 & 0.75 & 0.75 \\
\hline Subtotal & & 3.02 & 3.66 & 6.68 & 6.68 \\
\hline Total & & 3.08 & 3.73 & 6.81 & 6.81 \\
\hline
\end{tabular}

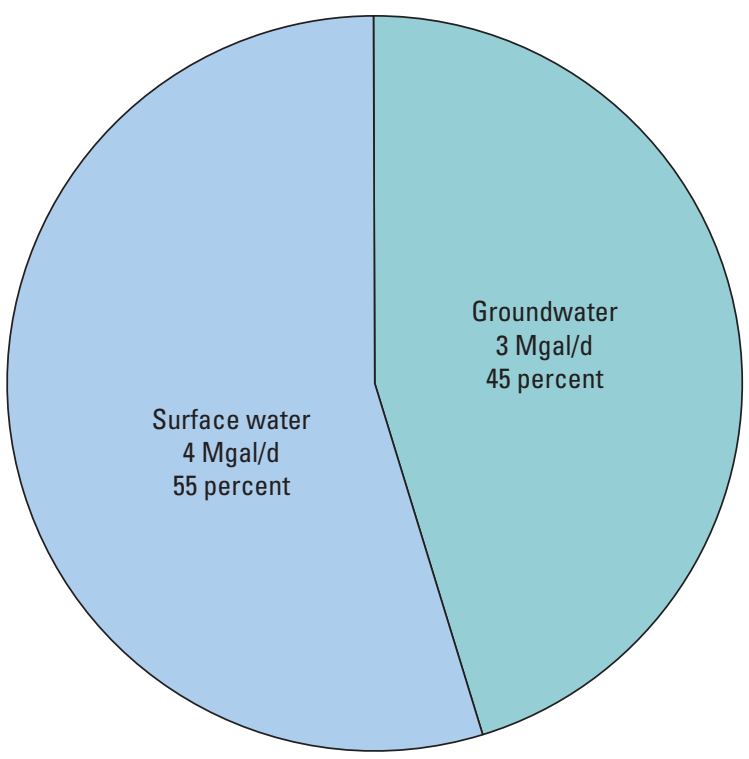

Figure 18. Source of water for livestock use in the Tennessee River watershed in Alabama, 2005. 
Total
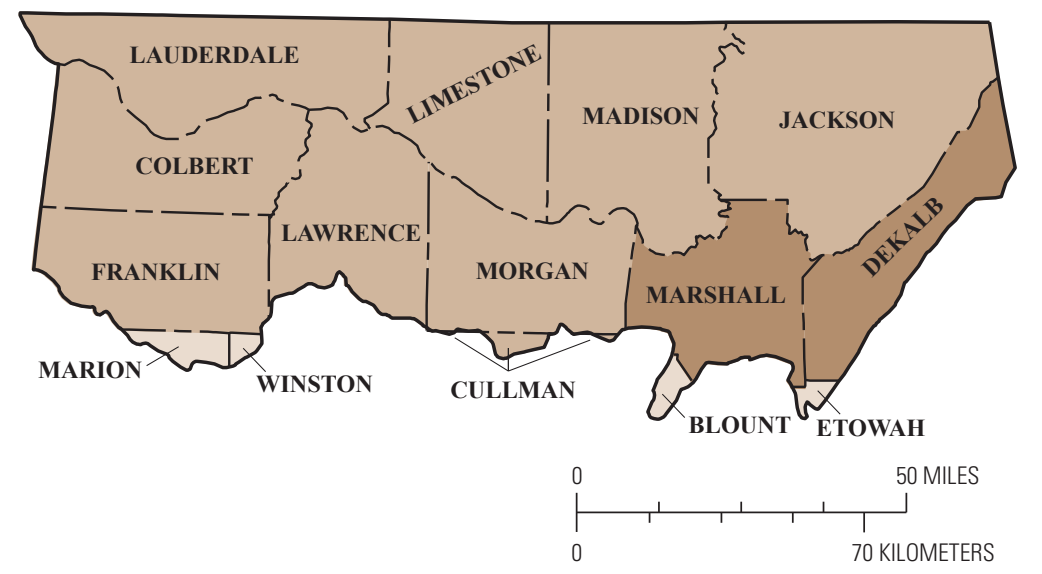

(1)

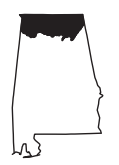

Location of the Tennessee River watershed in Alabama

\section{EXPLANATION}

Livestock withdrawals by county, in million gallons per day

$$
0.01 \text { to } 0.09
$$

0.10 to 0.99

1 to 1.99
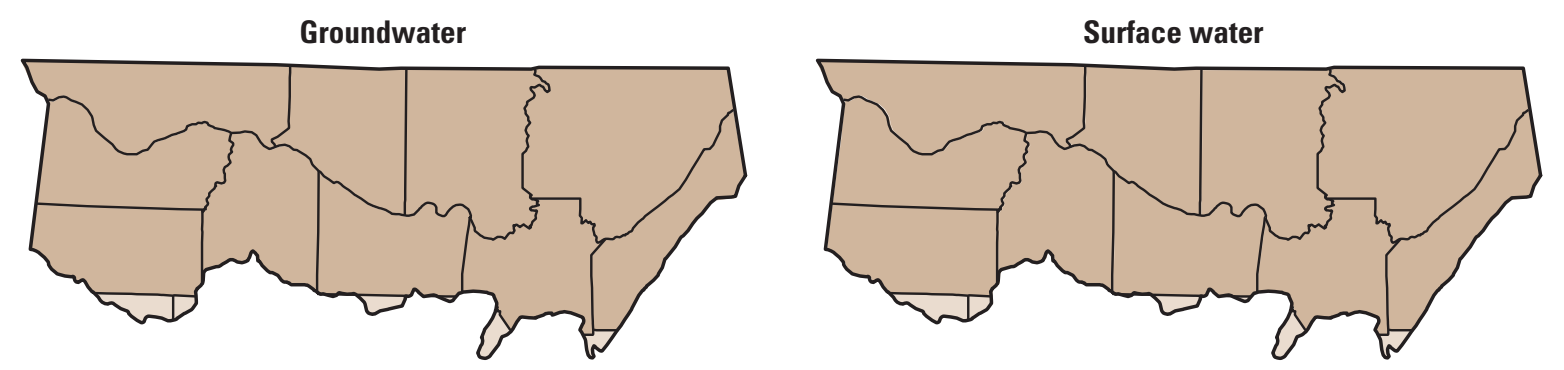

Figure 19. Withdrawals for livestock by source and county in the Tennessee River watershed in Alabama, 2005.
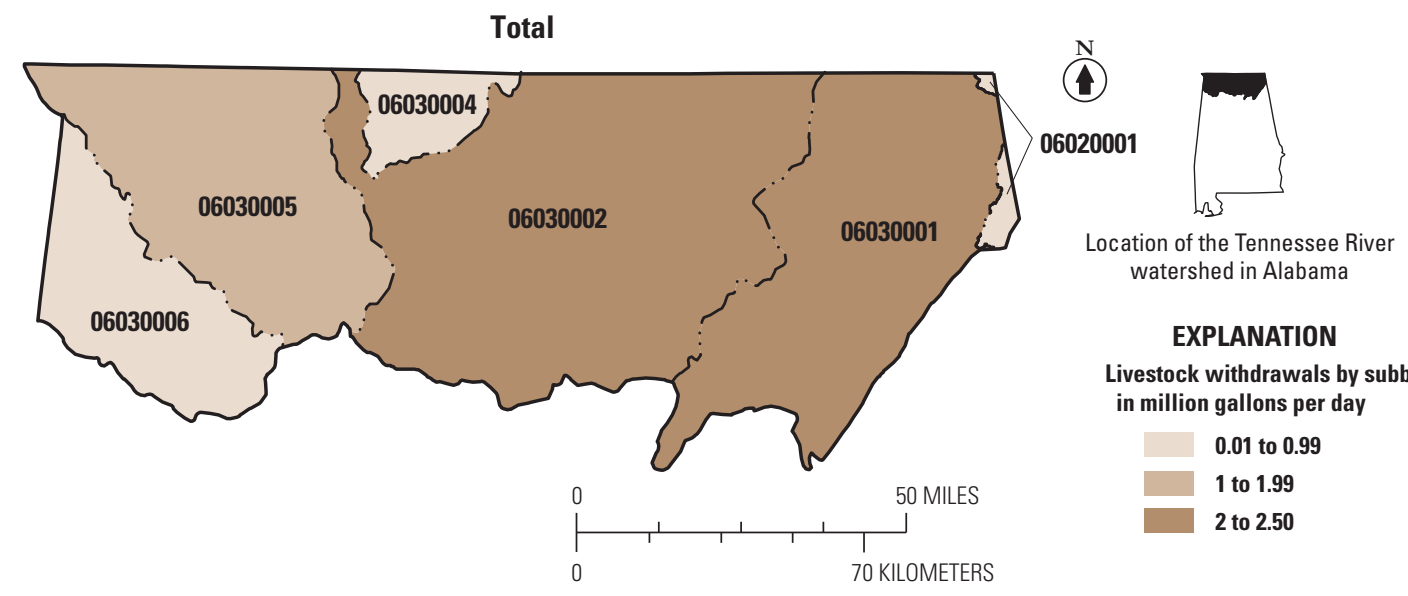

\section{EXPLANATION}

Livestock withdrawals by subbasin,

in million gallons per day

0.01 to 0.99

1 to 1.99

2 to 2.50

Groundwater

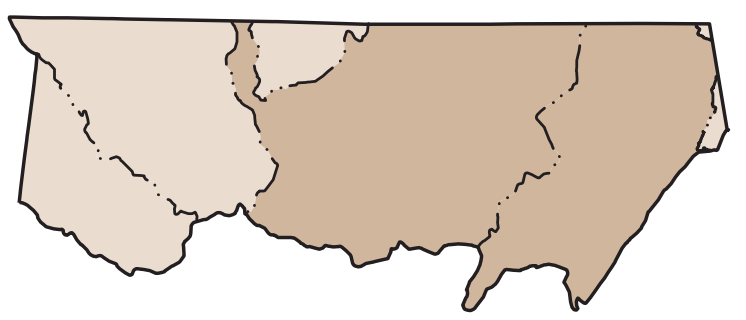

Surface water

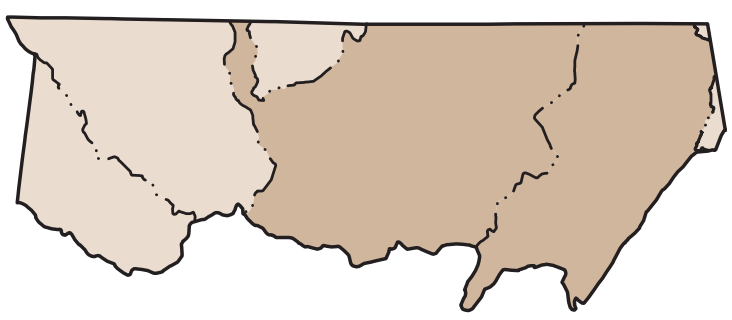

Figure 20. Withdrawals for livestock by source and subbasin in the Tennessee River watershed in Alabama, 2005. 


\section{Self-Supplied Industrial}

Industrial water is water used for fabrication, processing, washing, and cooling and includes such industries as chemical and allied products, food, paper and allied products, petroleum refining, and steel. Industries can purchase water from a public supply, be self-supplied, or both. Estimates of public-supplied industrial water deliveries were not made for the Tennessee River watershed in Alabama in 2005. Site-specific information reported to the AWURP was used to calculate self-supplied industrial water use in the watershed.

Self-supplied industrial withdrawals are listed by county and by hydrologic subbasin in tables 18 and 19, respectively. For 2005, self-supplied industrial withdrawals in the Tennessee River watershed in Alabama were $214 \mathrm{Mgal} / \mathrm{d}$, which is about 4 percent of total withdrawals and about 49 percent of total withdrawals excluding thermoelectric power (table 5). Surface water was the source for 99 percent $(212 \mathrm{Mgal} / \mathrm{d}$ ) of the withdrawals, and groundwater was the source of the remaining 1 percent ( $2 \mathrm{Mgal} / \mathrm{d}$; fig. 21).
The geographic distributions of total, groundwater, and surface-water withdrawals for self-supplied industrial use by county and by hydrologic subbasin are shown in figures 22 and 23, respectively. Withdrawals for self-supplied industrial use occurred in only 6 of the 15 counties. The largest withdrawals occurred in Morgan, Colbert (primarily chemical and allied products), and Lawrence Counties with withdrawals that were more than $50 \mathrm{Mgal} / \mathrm{d}$ each. Withdrawals in these counties accounted for about 95 percent (204 Mgal/d) of the total selfsupplied industrial withdrawals.

No industrial withdrawals were reported in the Middle Tennessee-Hiwassee subregion. In the Middle Tennessee-Elk hydrologic subregion, most industrial withdrawals were made by the chemical, paper, and the allied industries (table19; fig. 24). Within the Middle Tennessee-Elk hydrologic subregion, the largest total self-supplied industrial withdrawals occurred in the Wheeler Lake (HUC 06030002) and Pickwick Lake (HUC 06030005) subbasins (table 19).

Table 18. Self-supplied industrial water withdrawals, returns, and net demand by county in the Tennessee River watershed within Alabama, 2005.

[Figures may not sum to totals because of independent rounding. County names in bold indicate counties entirely contained within the watershed]

\begin{tabular}{|c|c|c|c|c|c|}
\hline \multirow{2}{*}{ County } & \multicolumn{3}{|c|}{ Withdrawals, in million gallons per day } & \multirow{2}{*}{$\begin{array}{c}\text { Return flows, } \\
\text { in million gallons } \\
\text { per day }\end{array}$} & \multirow{2}{*}{$\begin{array}{c}\text { Consumption, in } \\
\text { million gallons } \\
\text { per day }\end{array}$} \\
\hline & Groundwater & $\begin{array}{c}\text { Surface } \\
\text { water }\end{array}$ & Total & & \\
\hline Blount & 0.00 & 0.00 & 0.00 & 0.00 & 0.00 \\
\hline Colbert & 0.87 & 55.57 & 56.44 & 53.39 & 3.05 \\
\hline Cullman & 0.00 & 0.00 & 0.00 & 0.00 & 0.00 \\
\hline DeKalb & 0.00 & 0.00 & 0.00 & 0.00 & 0.00 \\
\hline Etowah & 0.00 & 0.00 & 0.00 & 0.00 & 0.00 \\
\hline Franklin & 0.00 & 0.00 & 0.00 & 0.00 & 0.00 \\
\hline Jackson & 0.00 & 8.78 & 8.78 & 8.12 & 0.66 \\
\hline Lauderdale & 0.00 & 0.00 & 0.00 & 0.00 & 0.00 \\
\hline Lawrence & 0.00 & 57.18 & 57.18 & 52.20 & 4.98 \\
\hline Limestone & 0.00 & 0.00 & 0.00 & 0.06 & -0.06 \\
\hline Madison & 0.00 & 0.89 & 0.89 & 0.93 & -0.04 \\
\hline Marion & 0.00 & 0.00 & 0.00 & 0.00 & 0.00 \\
\hline Marshall & 0.04 & 0 & 0.04 & 0.15 & -0.11 \\
\hline Morgan & 1.29 & 89.36 & 90.65 & 90.48 & 0.17 \\
\hline Winston & 0.00 & 0.00 & 0.00 & 0.00 & 0.00 \\
\hline Total & 2.20 & 211.78 & 213.98 & 205.34 & 8.65 \\
\hline
\end{tabular}


Table 19. Self-supplied industrial water withdrawals, returns, and net demands by hydrologic subregion and subbasin in the Tennessee River watershed within Alabama, 2005.

[Figures may not sum to totals because of independent rounding]

\begin{tabular}{|c|c|c|c|c|c|c|}
\hline \multirow{2}{*}{\multicolumn{2}{|c|}{ Hydrologic subregion and subbasin }} & \multicolumn{3}{|c|}{$\begin{array}{c}\text { Withdrawals, } \\
\text { in million gallons per day }\end{array}$} & \multirow{2}{*}{$\begin{array}{l}\text { Return flow, in } \\
\text { million gallons } \\
\quad \text { per day }\end{array}$} & \multirow{2}{*}{$\begin{array}{c}\text { Consumption, in } \\
\text { million gallons per day } \\
\text { Net water demand }\end{array}$} \\
\hline & & Groundwater & $\begin{array}{l}\text { Surface } \\
\text { water }\end{array}$ & Total & & \\
\hline \multicolumn{7}{|c|}{ Middle Tennessee-Hiwassee } \\
\hline 06020001 & $\begin{array}{l}\text { Middle Tennessee-- } \\
\text { Chickamauga }\end{array}$ & 0 & 0 & 0.00 & 0.00 & 0.00 \\
\hline Subtotal & & 0 & 0 & 0.00 & 0.00 & 0.00 \\
\hline \multicolumn{7}{|c|}{ Middle Tennessee-Elk } \\
\hline 06030001 & Guntersville Lake & 0.04 & 8.78 & 8.82 & 8.12 & 0.70 \\
\hline 06030002 & Wheeler Lake & 1.29 & 147.43 & 148.72 & 143.83 & 4.89 \\
\hline 06030004 & Lower Elk & 0.00 & 0.00 & 0.00 & 0.00 & - \\
\hline 06030005 & Pickwick Lake & 0.87 & 55.57 & 56.44 & 53.39 & 3.05 \\
\hline 06030006 & Bear & 0.00 & 0.00 & 0.00 & 0.00 & - \\
\hline Subtotal & & 2.20 & 211.78 & 213.98 & 205.34 & 8.64 \\
\hline Total & & 2.20 & 211.78 & 213.98 & 205.34 & 8.64 \\
\hline
\end{tabular}

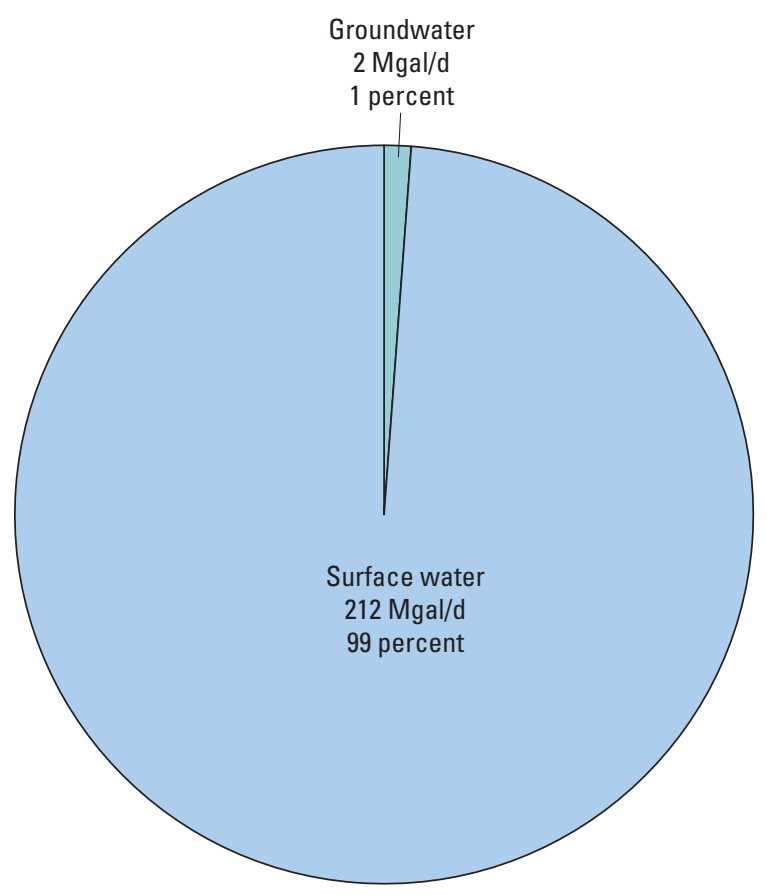

Figure 21. Source of water for self-supplied industrial use in the Tennessee River watershed in Alabama, 2005. 
Total
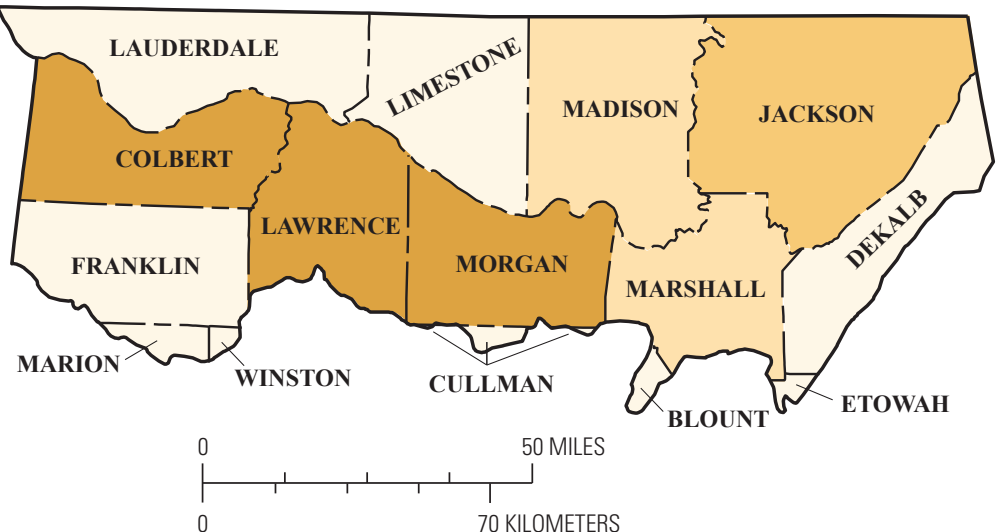

(1)

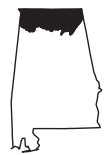

Location of the Tennessee River watershed in Alabama

EXPLANATION

Industrial withdrawals by county,

in million gallons per day

0.01 to 4.99

5 to 9.99

10 to 100
Groundwater

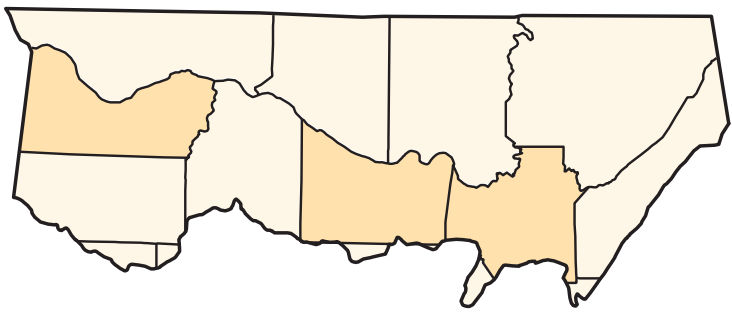

Surface water

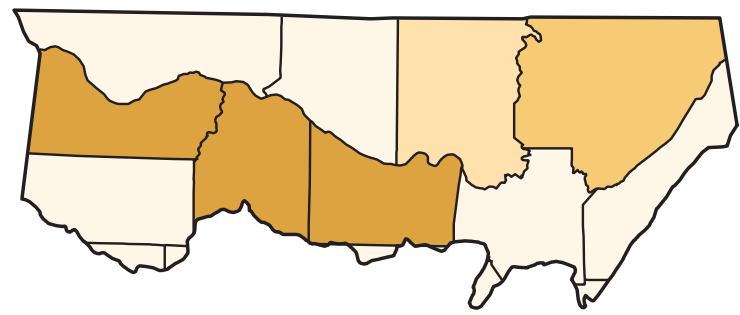

Figure 22. Self-supplied industrial freshwater withdrawals by source and county in the Tennessee River watershed in Alabama, 2005.

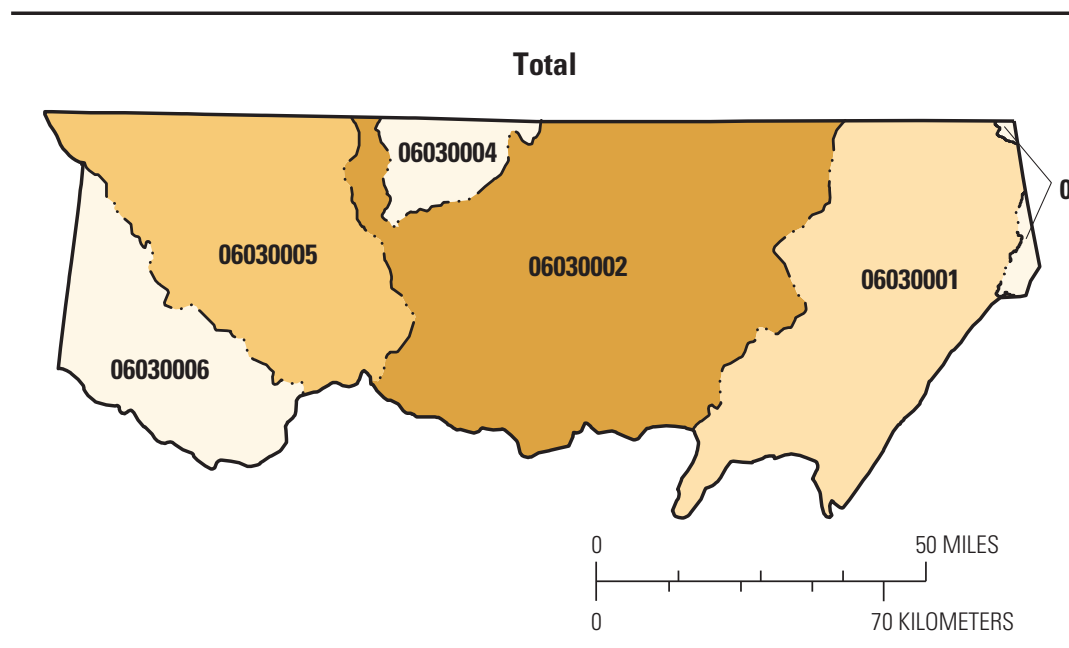

(ิ) 06020001

\section{Location of the Tennessee River watershed in Alabama}

\section{EXPLANATION}

Industrial withdrawals by subbasin,

in million gallons per day

0

0.01 to 9.99

10 to 99.99

100 to 150
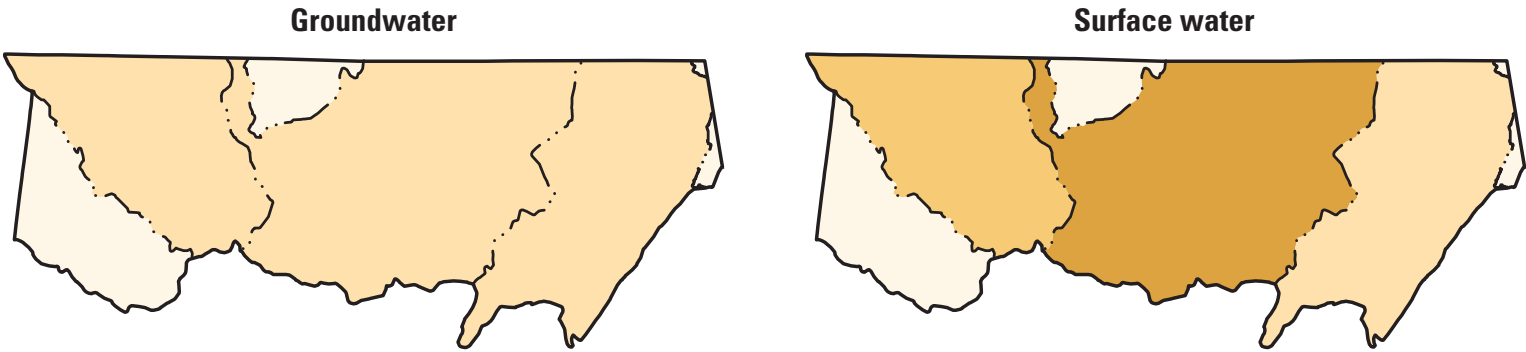

Figure 23. Self-supplied industrial freshwater withdrawals by source and subbasin in the Tennessee River watershed in Alabama, 2005. 


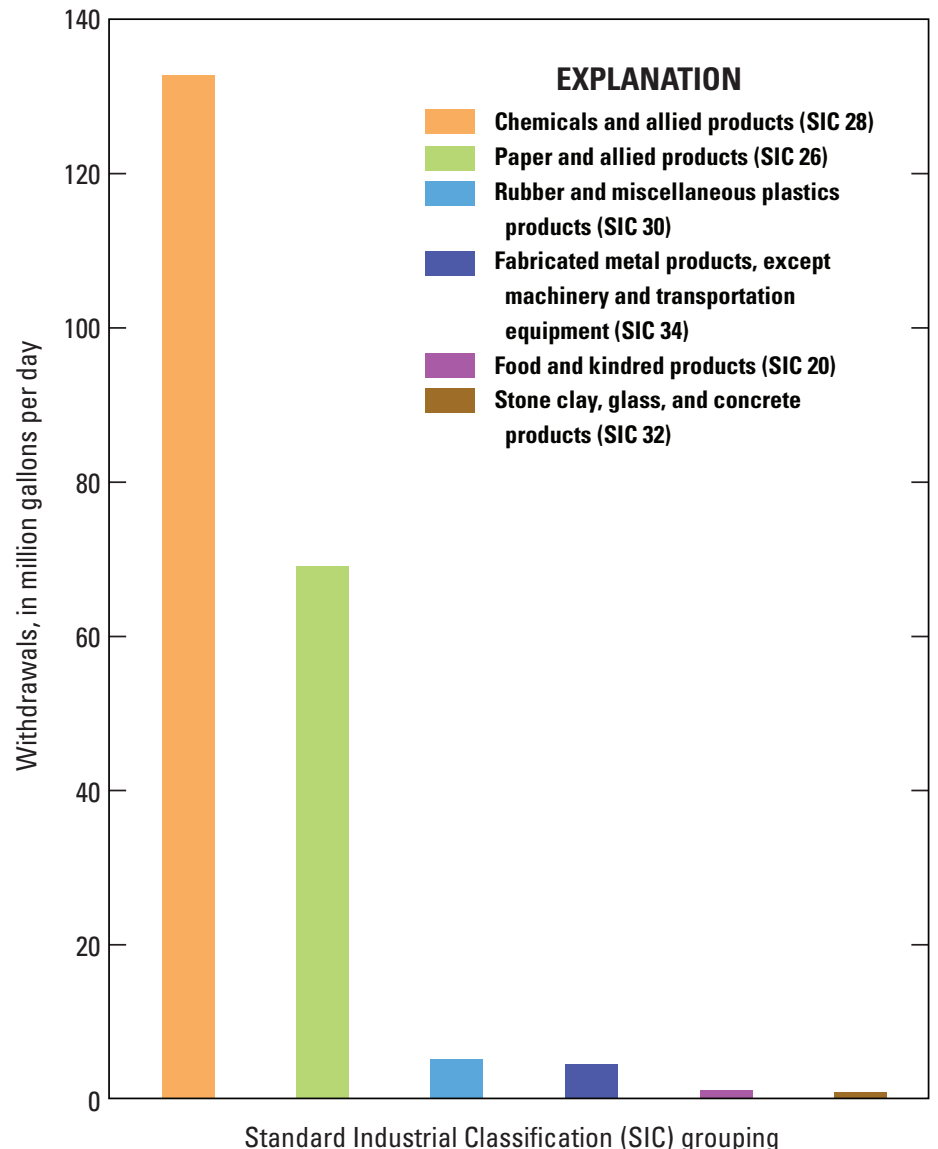

Paper and allied products (Standard Industrial Classification [SIC] 26, $69 \mathrm{Mgal} / \mathrm{d}$ ) and chemicals and allied products (SIC 28, $133 \mathrm{Mgal} / \mathrm{d}$ ) accounted for 94 percent of total self-supplied industrial withdrawals in the Tennessee River watershed in Alabama (fig. 24). Chemicals and allied products accounted for the largest self-supplied industrial surface-water withdrawals (133 Mgal/d), and food and kindred products (1 Mgal/d) accounted for the largest selfsupplied industrial groundwater withdrawals (table 20).
Figure 24. Distribution of total industrial withdrawals by Standard Industrial Classification grouping in the Tennessee River watershed within Alabama, 2005.

Table 20. Self-supplied industrial water withdrawals by Standard Industrial Classification and by source in the Tennessee River watershed in Alabama, 2005.

\begin{tabular}{|c|c|c|c|c|}
\hline \multirow{2}{*}{\multicolumn{2}{|c|}{ Standard Industrial Classification }} & \multicolumn{3}{|c|}{ Water withdrawals, in million gallons per day } \\
\hline & & \multirow{2}{*}{$\begin{array}{c}\text { Groundwater } \\
1.18\end{array}$} & \multirow{2}{*}{$\frac{\text { Surface water }}{0.00}$} & \multirow{2}{*}{$\begin{array}{c}\text { Total } \\
1.18\end{array}$} \\
\hline 20 & Food and kindred products & & & \\
\hline 22 & Textile mill products & 0.00 & 0.25 & 0.25 \\
\hline 26 & Paper and allied products & 0.00 & 69.01 & 69.01 \\
\hline 28 & $\begin{array}{l}\text { Chemicals and allied } \\
\text { products }\end{array}$ & 0.16 & 132.62 & 132.78 \\
\hline 30 & $\begin{array}{l}\text { Rubber and miscellaneous } \\
\text { plastics products }\end{array}$ & 0.00 & 5.27 & 5.27 \\
\hline 34 & $\begin{array}{l}\text { Fabricated metal products, } \\
\text { except machinery and } \\
\text { transportation equipment }\end{array}$ & 0.87 & 3.72 & 4.59 \\
\hline \multirow[t]{2}{*}{32} & $\begin{array}{l}\text { Stone, clay, glass, and } \\
\text { concrete products }\end{array}$ & 0.00 & 0.89 & 0.89 \\
\hline & Total & 2.20 & 211.76 & 213.96 \\
\hline
\end{tabular}




\section{Mining}

Mining water refers to water that is used for the extraction of naturally occurring minerals including solids, such as coal, sand, gravel, and other ores; liquids, such as crude petroleum; and gases, such as natural gas. Mining also includes uses associated with quarrying, milling, and other preparations customarily done at a mine site or as part of a mining activity. Mining water use does not include water associated with dewatering of an aquifer that is not put to beneficial use and also does not include water used in processing, such as smelting, refining petroleum, or slurry pipeline operations. These processing uses are included in the industrial category.

Mining water withdrawals are listed by county in table 21. For the Tennessee River watershed in 2005, total mining withdrawals were $3 \mathrm{Mgal} / \mathrm{d}$, which is less than 0.01 percent of total withdrawals and nearly 0.7 percent of total withdrawals for all categories excluding thermoelectric power (table 5). Groundwater was the source of about 56 percent $(1.7 \mathrm{Mgal} / \mathrm{d})$ of withdrawals, and surface water was the source of the remaining 44 percent (1.3 Mgal/d) (fig. 25).

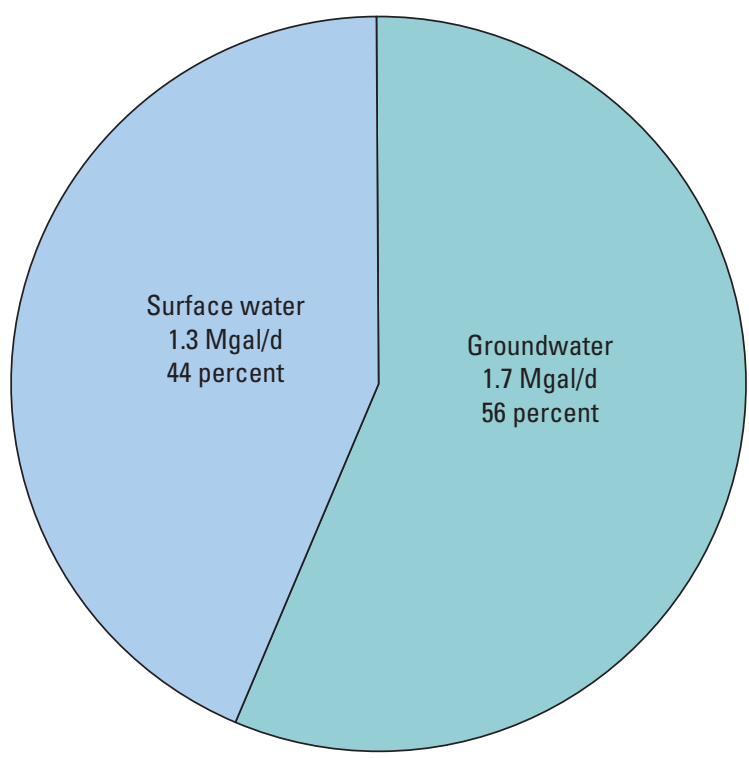

Figure 25. Source of water for mining use in the Tennessee River watershed in Alabama, 2005.

Table 21. Mining water withdrawals, returns, and net demands by county in the Tennessee River watershed within Alabama, 2005.

[Figures may not sum to totals because of independent rounding. County names in bold type indicate counties entirely contained within the watershed]

\begin{tabular}{lccccc}
\hline \multirow{2}{*}{ County } & \multicolumn{2}{c}{ Withdrawals, in million gallons per day } & Return flow & $\begin{array}{c}\text { Consumption, in million } \\
\text { gallons per day }\end{array}$ \\
\cline { 2 - 4 } & Groundwater & Surface water & Total & & Net water demand \\
\hline Blount & 0.04 & 0.00 & 0.04 & 0.00 & 0.04 \\
Colbert & 0.00 & 0.05 & 0.05 & 0.00 & 0.05 \\
Cullman & 0.00 & 0.00 & 0.00 & 0.00 & 0.00 \\
DeKalb & 0.00 & 0.00 & 0.00 & 0.00 & 0.00 \\
Etowah & 0.00 & 0.00 & 0.00 & 0.00 & 0.00 \\
Franklin & 0.39 & 0.18 & 0.57 & 0.00 & 0.57 \\
Jackson & 0.07 & 0.03 & 0.10 & 0.00 & 0.10 \\
Lauderdale & 0.00 & 0.00 & 0.00 & 0.00 & 0.00 \\
Lawrence & 0.16 & 0.07 & 0.23 & 0.00 & 0.23 \\
Limestone & 0.00 & 0.50 & 0.50 & 0.00 & 0.50 \\
Madison & 0.48 & 0.22 & 0.70 & 0.00 & 0.70 \\
Marion & 0.00 & 0.00 & 0.00 & 0.00 & 0.00 \\
Marshall & 0.19 & 0.09 & 0.28 & 0.00 & 0.28 \\
Morgan & 0.37 & 0.17 & 0.54 & 0.00 & 0.54 \\
Winston & 0.00 & 0.00 & 0.00 & 0.00 & 0.00 \\
\hline Total & $\mathbf{1 . 7 0}$ & $\mathbf{1 . 3 1}$ & $\mathbf{3 . 0 1}$ & $\mathbf{0 . 0 0}$ & $\mathbf{3 . 0 1}$ \\
\hline
\end{tabular}


The geographic distributions of total, groundwater, and surface-water withdrawals for mining use by county are shown in figure 26. Six of the 15 counties in the Tennessee River watershed had no mining water use in 2005 , and each of the counties with mining activities had withdrawals of $0.7 \mathrm{Mgal} / \mathrm{d}$ or less (table 21). Most of the permitted mining facilities in the Tennessee River watershed in Alabama were crushed stone or sand and gravel plants. A few coal mines also were operated in this part of Alabama.
Mining water withdrawals were summarized for each of the hydrologic subbasins (table 22; fig. 27). The Middle Tennessee-Chickamauga (HUC 06020001) subbasin in Alabama had no mining activity. The Wheeler Lake (HUC 06030002) subbasin had the greatest mining water withdrawals, $1.39 \mathrm{Mgal} / \mathrm{d}$, or about 46 percent of the mining withdrawals for the Tennessee River watershed in Alabama. Mining water withdrawals in the remaining four subbasins ranged from 0.26 to $0.51 \mathrm{Mgal} / \mathrm{d}$.

\section{Total}
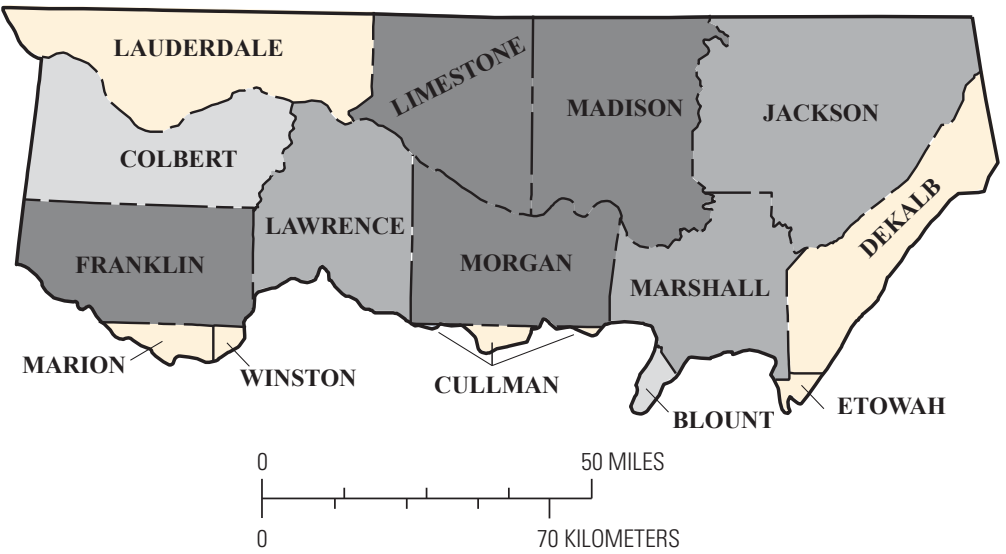

Groundwater

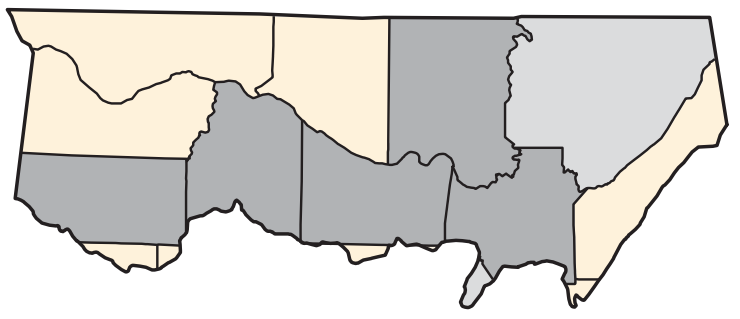

$\stackrel{N}{(-1}$

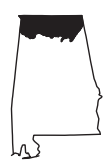

Location of the Tennessee River watershed in Alabama

\section{EXPLANATION}

Mining withdrawals by county, in million gallons per day

0

0.01 to 0.09

0.1 to 0.49

0.50 to 1

Figure 26. Mining freshwater withdrawals by source and county in the Tennessee River watershed in Alabama, 2005. 
Table 22. Mining water withdrawals, returns, and net demands by hydrologic subregion and subbasin in the Tennessee River watershed within Alabama, 2005.

[Figures may not sum to totals because of independent rounding]

\begin{tabular}{|c|c|c|c|c|c|c|}
\hline \multicolumn{2}{|c|}{ Hydrologic subregion and subbasin } & \multicolumn{3}{|c|}{$\begin{array}{l}\text { Withdrawals, in } \\
\text { million gallons per day }\end{array}$} & \multirow{2}{*}{$\begin{array}{l}\text { Return flow, } \\
\text { in million } \\
\text { gallons per day }\end{array}$} & \multirow{2}{*}{$\begin{array}{c}\begin{array}{c}\text { Consumption, } \\
\text { in million } \\
\text { gallons per day }\end{array} \\
\text { Net water demand }\end{array}$} \\
\hline & & Groundwater & Surface water & Total & & \\
\hline \multicolumn{7}{|c|}{ Middle Tennessee-Hiwassee } \\
\hline 06020001 & $\begin{array}{l}\text { Middle Tennessee-- } \\
\text { Chickamauga }\end{array}$ & 0.00 & 0.00 & 0.00 & 0.00 & 0.00 \\
\hline Subtotal & & 0.00 & 0.00 & 0.00 & 0.00 & 0.00 \\
\hline \multicolumn{7}{|c|}{ Middle Tennessee-Elk } \\
\hline 06030001 & Guntersville Lake & 0.26 & 0.1 & 0.36 & 0.00 & 0.36 \\
\hline 06030002 & Wheeler Lake & 0.95 & 0.44 & 1.39 & 0.00 & 1.39 \\
\hline 06030004 & Lower Elk & 0.00 & 0.5 & 0.50 & 0.00 & 0.50 \\
\hline 06030005 & Pickwick Lake & 0.15 & 0.11 & 0.26 & 0.00 & 0.26 \\
\hline 06030006 & Bear & 0.34 & 0.17 & 0.51 & 0.00 & 0.51 \\
\hline Subtotal & & 1.70 & 1.32 & 3.02 & 0.00 & 3.02 \\
\hline Total & & 1.70 & 1.32 & 3.02 & 0.00 & 3.02 \\
\hline
\end{tabular}

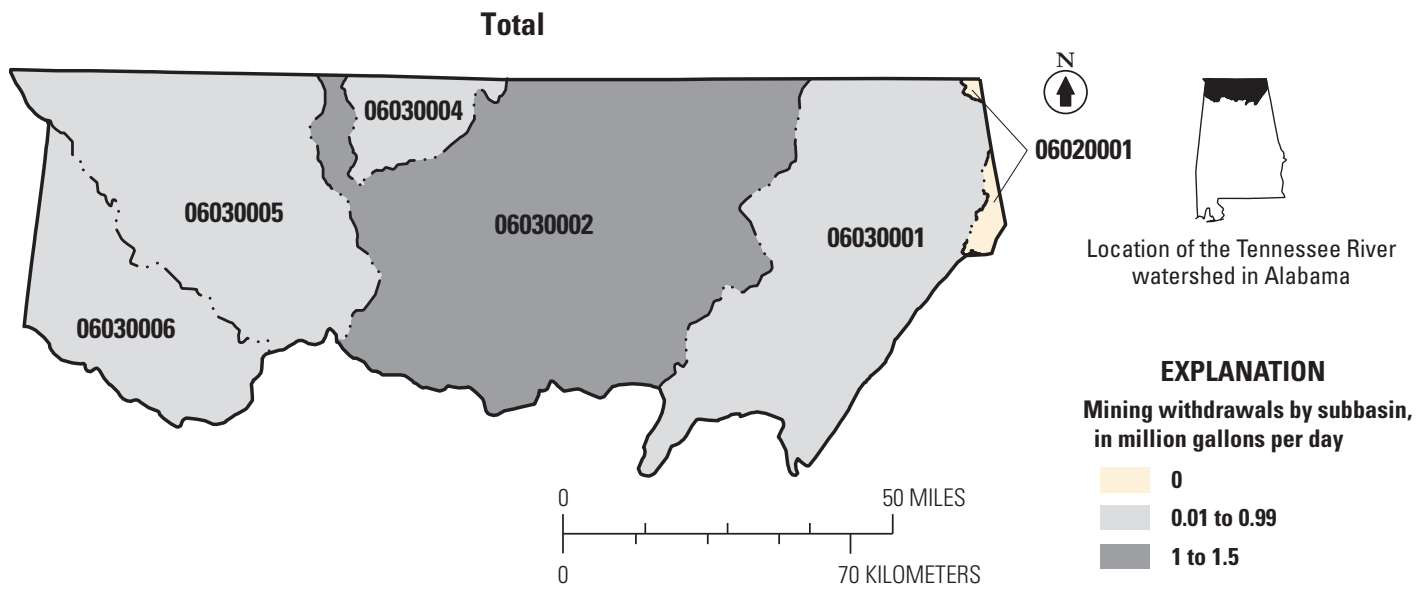

Groundwater

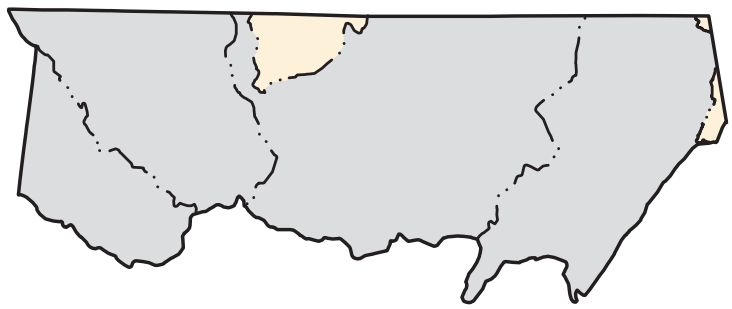

Surface water

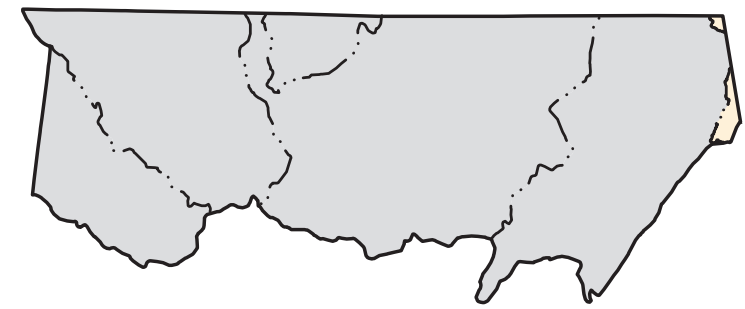

Figure 27. Mining withdrawals by source and subbasin in the Tennessee River watershed in Alabama, 2005. 


\section{Thermoelectric Power}

Thermoelectric power water is water used in the process of generating electricity with steam-driven turbine generators and for other onsite needs. Once-through cooling (also known as open-loop cooling) of power generation plants refers to cooling systems in which water is withdrawn from a source, circulated through heat exchangers, and then returned to a surface-water body. All thermoelectric-power water use in the Tennessee River watershed in Alabama was for once-through cooling using surface water as the source of cooling water, with more than 99 percent of the cooling water being returned to its source in 2005 .

In 2005, four thermoelectric power plants in the Tennessee River watershed in Alabama used 4,762 Mgal/d of surface water for cooling to produce 36,747 gigawatt-hours of energy. Total thermoelectric power water withdrawals are listed by county and hydrologic subbasin in tables 23 and 24. Only four counties in the Tennessee River watershed in AlabamaColbert (1,294 Mgal/d), Jackson (1,476 Mgal/d), Limestone (1,990 Mgal/d), and Morgan (1 Mgal/d)—had thermoelectric power water withdrawals. These withdrawals occurred in the Guntersville Lake (HUC 06030001; 1,476 Mgal/d), Wheeler Lake (HUC 06030002; 1,991 Mgal/d), and Pickwick Lake (HUC 06030005; 1,294 Mgal/d) subbasins. Thermoelectric power withdrawals accounted for 92 percent of total water withdrawals and 93 percent of total surface-water withdrawals in the Tennessee River watershed in Alabama (tables 5 and 7). The geographic distributions of total withdrawals for thermoelectric power by county and hydrologic subbasin are shown in figures 28 and 29, respectively.

Table 23. Thermoelectric-power surface-water withdrawals and consumption by county in the Tennessee River watershed within Alabama, 2005.

[Values may not sum to total estimated use(s) because of rounding. County names in bold type indicate counties entirely contained within the watershed]

\begin{tabular}{lcccc}
\hline County & $\begin{array}{c}\text { Surface-water } \\
\text { withdrawals, } \\
\text { in million } \\
\text { gallons per day }\end{array}$ & $\begin{array}{c}\text { Return flow, } \\
\text { in million } \\
\text { gallons per day }\end{array}$ & $\begin{array}{c}\text { Consumption, } \\
\text { in million } \\
\text { gallons per day }\end{array}$ & $\begin{array}{c}\text { Total power } \\
\text { generated, in } \\
\text { gigawatt-hours }\end{array}$ \\
\hline Colbert & $1,294.14$ & $1,292.83$ & 1.31 & 7,743 \\
Jackson & $1,476.30$ & $1,476.29$ & 0.01 & 9,835 \\
Limestone & $1,990.24$ & $1,987.54$ & 2.70 & 17,955 \\
Morgan & 1.20 & 0.40 & 0.80 & 1,214 \\
\hline Total & $\mathbf{4 , 7 6 1 . 8 8}$ & $\mathbf{4 , 7 5 7 . 0 6}$ & $\mathbf{4 . 8 2}$ & $\mathbf{3 6 , 7 4 7}$ \\
\hline
\end{tabular}

Table 24. Thermoelectric-power surface-water withdrawals and consumption, and power generated by hydrologic subregion and subbasin in the Tennessee River watershed within Alabama, 2005.

\begin{tabular}{|c|c|c|c|c|c|}
\hline \multicolumn{2}{|c|}{ Hydrologic subregion and subbasin } & $\begin{array}{l}\text { Surface-water } \\
\text { withdrawals, } \\
\text { in million } \\
\text { gallons per day }\end{array}$ & $\begin{array}{c}\text { Return flow, } \\
\text { in million } \\
\text { gallons per day }\end{array}$ & \multirow{3}{*}{$\begin{array}{c}\text { Consumption, } \\
\text { in million } \\
\text { gallons per day } \\
\text { Net water demand }\end{array}$} & $\begin{array}{c}\text { Total power } \\
\text { generated, in } \\
\text { gigawatt-hours }\end{array}$ \\
\hline \multirow{2}{*}{\multicolumn{5}{|c|}{ Middle Tennessee-Hiwassee }} & \\
\hline & & & & & \\
\hline 06020001 & $\begin{array}{l}\text { Middle Tennessee- } \\
\text { Chickamauga }\end{array}$ & 0.00 & 0.00 & 0.00 & 0 \\
\hline Subtotal & & 0.00 & 0.00 & 0.00 & 0 \\
\hline \multicolumn{6}{|c|}{ Middle Tennessee-Elk } \\
\hline 06030001 & Guntersville Lake & $1,476.30$ & $1,476.29$ & 0.01 & 9,835 \\
\hline 06030002 & Wheeler Lake & $1,991.44$ & $1,987.94$ & 3.50 & 19,169 \\
\hline 06030004 & Lower Elk & 0.00 & 0.00 & 0.00 & 0 \\
\hline 06030005 & Pickwick Lake & $1,294.14$ & $1,292.83$ & 1.31 & 7,743 \\
\hline 06030006 & Bear & 0.00 & 0.00 & 0.00 & 0 \\
\hline Subtotal & & $4,761.88$ & $4,757.06$ & 4.82 & 36,747 \\
\hline Total & & $4,761.88$ & $4,757.06$ & 4.82 & 36,747 \\
\hline
\end{tabular}


Total (surface water)
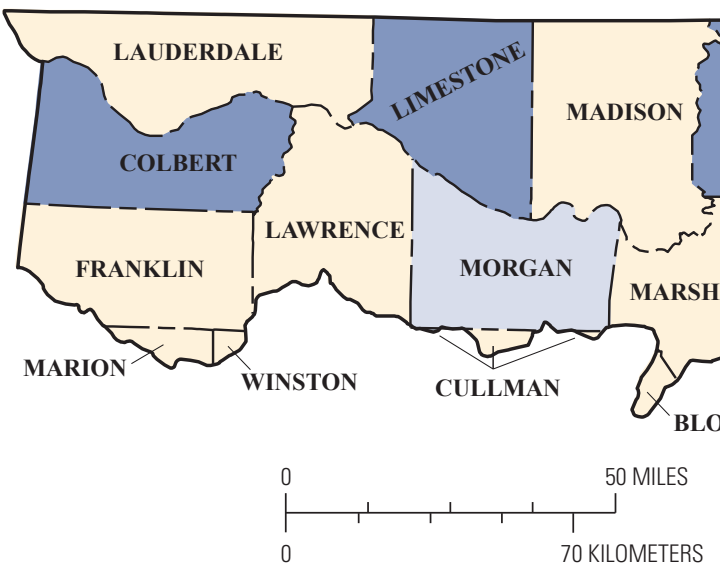

(

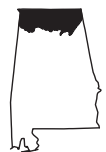

Location of the Tennessee River watershed in Alabama

\section{EXPLANATION}

Thermoelectric withdrawals by county, in million gallons per day

ETOWAH

0.01 to 99.99

1,000 to 2,000

Figure 28. Thermoelectric-power freshwater withdrawals (all surface water) by county in the Tennessee River watershed in Alabama, 2005
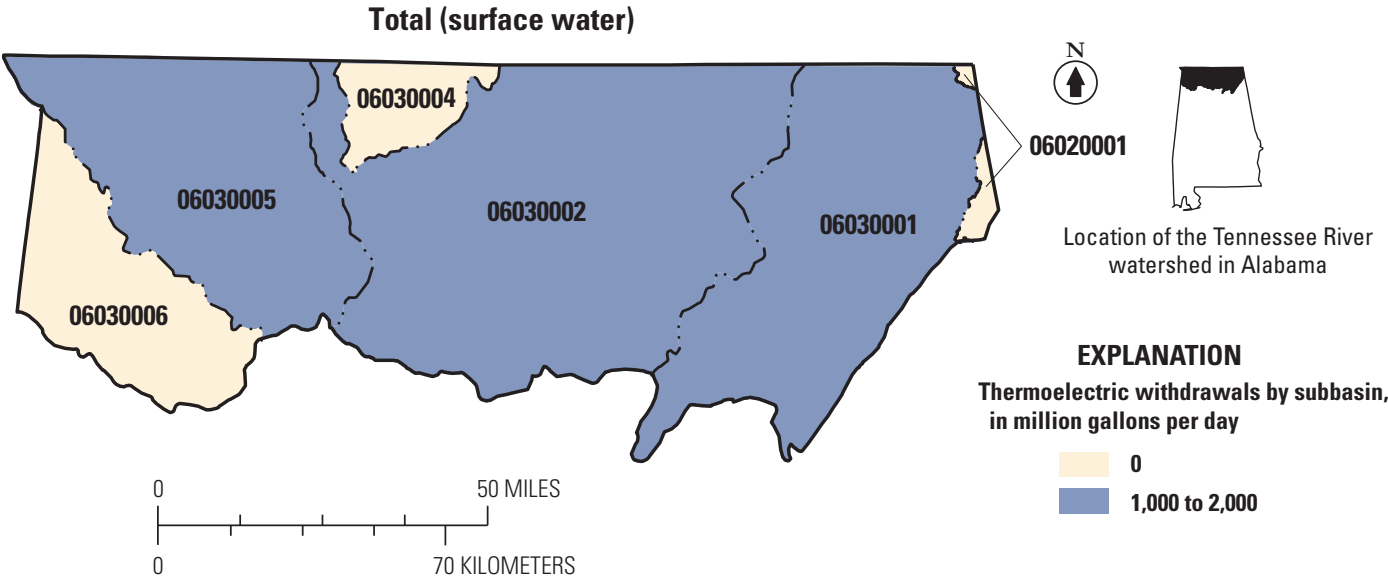

Thermoelectric withdrawals by subbasin, in million gallons per day

$$
0
$$

1,000 to 2,000

Figure 29. Thermoelectric-power freshwater withdrawals (all surface water) by subbasin in the Tennessee River watershed in Alabama, 2005 


\section{Water Availability}

Water availability in the Tennessee River watershed of Alabama has previously been described in multiple reports. Most recently, reports by staff of the TVA and the GSA have included estimates of water availability for the region (Bohac and Koroa, 2004; Bohac and McCall, 2008; Cook and others, 2009). The conclusions of these reports are summarized herein to provide an estimate of the water availability in the region.

The GSA estimated amounts of water available to users in the Tennessee River watershed in Alabama from streamflow data from 20 long-term streamgaging stations. Data from the streamgaging stations were used to estimate groundwater recharge and surface-water availability per unit area (Cook and others, 2009). The methods and results of this investigation are described in further detail in the Groundwater Availability section of this report.

The TVA also assessed surface-water availability and summarized 2005 net water demand for four major water uses in the watershed, compared use in 2005 to previous years, and projected water use for the year 2030 (Bohac and Koroa, 2004; Bohac and McCall, 2008). Withdrawal and return information for 2005 for thermoelectric, public-supply, industrial, and irrigation water uses was summarized by political and hydrologic boundaries.

\section{Groundwater Availability}

The amount of available groundwater is related to the amount of storage in the groundwater system. Many of the water-bearing geologic formations in the Tennessee River watershed within Alabama are characterized by fractures and cavities that may provide large amounts of groundwater but are not uniformly distributed (Cook and others, 2009). Though estimates of groundwater availability have been generated for the region, accessibility and availability at any given location in the watershed are largely unknown.

Estimates of baseflow were assumed by Cook and others (2009) to be a reasonable estimate of annual groundwater recharge. In turn, annual groundwater recharge was assumed to be an acceptable estimate of groundwater availability for a given area. Because areas of similar geology and stratigraphy might reasonably be expected to have similar groundwater yield, the GSA designated six geologic areas (fig. 30) of similar characteristics for estimating groundwater availability in the region. The GSA used the recharge rates estimated from the baseflow analyses multiplied by the area of each geologic area to determine a total annual groundwater yield for the geologic area and a rate of recharge/availability in thousand gallons per day per square mile for each geologic area. Based on geologic areas, total groundwater availability for the entire Tennessee River watershed in Alabama was estimated to be 1,967 Mgal/d (Cook and others, 2009; table 25).
Table 25. Estimated available groundwater in the Tennessee River watershed in Alabama (modified from Cook and others, 2009; refer to figure 30 for location of geologic areas).

\begin{tabular}{lccc}
\hline \multirow{2}{*}{$\begin{array}{c}\text { Geologic } \\
\text { area }\end{array}$} & $\begin{array}{c}\text { Available groundwater } \\
\text { Ber year }\end{array}$ & $\begin{array}{c}\text { Million gallons } \\
\text { per day }\end{array}$ & $\begin{array}{c}\text { Thousand } \\
\text { gallons per day } \\
\text { per square mile }\end{array}$ \\
\hline 1 & 108.9 & 298.4 & 265.2 \\
2 & 53.8 & 147.3 & 158.0 \\
3 & 304.0 & 832.8 & 376.2 \\
4 & 129.7 & 355.4 & 266.6 \\
5 & 36.2 & 99.3 & 262.0 \\
6 & 85.5 & 234.1 & 266.6 \\
\hline Total & $\mathbf{7 1 8 . 1}$ & $\mathbf{1 , 9 6 7 . 3}$ & \\
\hline
\end{tabular}

\section{Surface-Water Availability}

The GSA also estimated surface-water availability for the Tennessee Valley watershed in Alabama (Cook and others, 2009). For the surface-water analysis, the GSA used streamflow data from the same 20 sites used for estimation of groundwater availability. For each site, the mean annual period of record streamflow was divided by the drainage area of the site's watershed. The resulting discharges per unit area, expressed as cubic feet per second per square mile $\left(\mathrm{ft}^{3} / \mathrm{mi}^{2}\right)$, were averaged for all sites within a hydrologic unit, and the average unit discharge was used to estimate surface-water availability for the entire area of the hydrologic unit. Average unit discharges and hydrologic-unit surface-water availabilities are summarized in table 26. Total surface-water availability originating in the Tennessee River watershed within Alabama was 8,200 Mgal/d. An additional 24,400 Mgal/d are supplied from the portion of the Tennessee River flowing into Alabama (Cook and others, 2009), so total surface-water availability was estimated to be $32,600 \mathrm{Mgal} / \mathrm{d}$ (Cook and others, 2009).

Table 26. Estimated available surface water in the Tennessee River watershed in Alabama (modified from Cook and others, 2009).

$\left[\mathrm{ft}^{3} / \mathrm{mi}^{2}\right.$, cubic feet per second per square mile; $\mathrm{ft}^{3} / \mathrm{d}$, cubic feet per day; $\mathrm{Mgal} / \mathrm{d}$, million gallons per day]

\begin{tabular}{lccc}
\hline $\begin{array}{c}\text { Hydrologic } \\
\text { subbasin }\end{array}$ & $\begin{array}{c}\text { Unit discharge } \\
\mathbf{f t}^{\mathbf{3}} / \mathbf{m i}^{\mathbf{2}}\end{array}$ & \multicolumn{2}{c}{ Available surface water } \\
\cline { 3 - 4 } & 1.96 & million ft $\mathbf{3} \mathbf{d}$ & $\mathbf{M g a l} / \mathbf{d}$ \\
\hline 06020001 & 1.96 & 282.1 & 100 \\
06030001 & 1.76 & 403.9 & 2,100 \\
06030002 & 1.68 & 38.2 & 3000 \\
06030004 & 1.83 & 225.2 & 1,700 \\
06030005 & 1.89 & 127.2 & 1,000 \\
06030006 & & $\mathbf{1 , 0 8 4 . 9}$ & $\mathbf{8 , 2 0 0}$ \\
\hline Total & & & \\
\hline
\end{tabular}




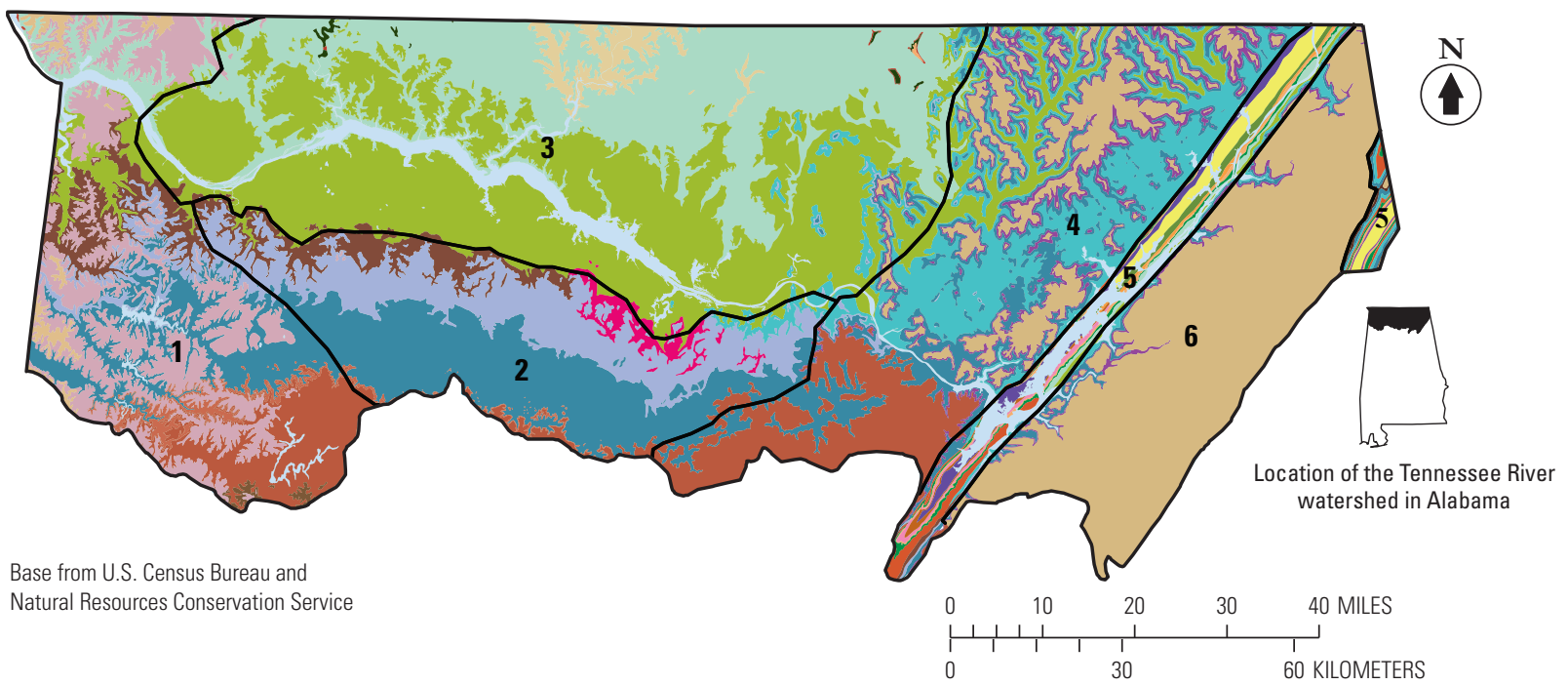

EXPLANATION

\begin{tabular}{|l|}
\hline Bangor limestone \\
\hline Chattanooga shale \\
\hline Chickamauga limestone \\
\hline Coker formation \\
\hline Eutaw formation \\
\hline Fort Payne chert \\
\hline Gordo formation \\
Hartselle sandstone \\
\hline Inman formation \\
\hline Knox group undifferentiated \\
Leipers limestone
\end{tabular}

Bangor limestone Chattanooga shale Chickamauga limestone Knox group undifferentiated

\begin{tabular}{|l|}
\hline Monteagle limestone \\
Nashville group \\
Nashville and Stones River groups \\
undifferentiated \\
Ordovician system undifferentiated \\
Parkwood formation \\
Parkwood and Pennington formations \\
undifferentiated \\
Pennington formation \\
Pottsville formation \\
Pottsville formation (lower part), \\
Appalachian Plateaus
\end{tabular}

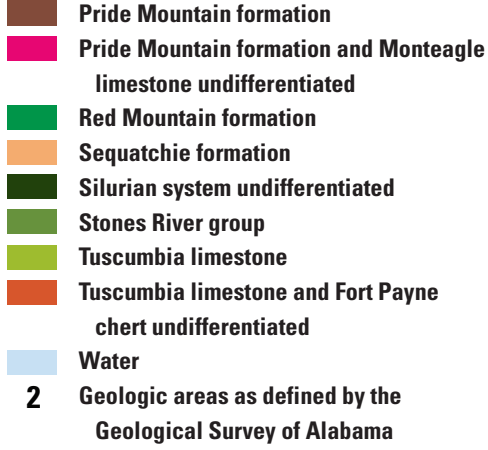

Figure 30. Geology and geologic areas within the Tennessee River watershed in Alabama. (Modified from Cook and others, 2009.)

\section{Water Availability and Net Water Demand}

The GSA estimated availability of approximately $1,967 \mathrm{Mgal} / \mathrm{d}$ of groundwater and 8,200 Mgal/d of surface water from the Tennessee River watershed within the State of Alabama. The GSA added the inflow of the Tennessee River to Alabama at an average rate of $24,400 \mathrm{Mgal} / \mathrm{d}$ to calculate a total surface-water availability in the Tennessee River watershed in Alabama of 32,600 Mgal/d. Total water availability for the Tennessee River watershed in Alabama including groundwater, surface water flowing into the State, and surface water originating within the State was estimated to be 34,567 Mgal/d.

The TVA evaluated water availability in terms of 2005 use and return flows (Bohac and Koroa, 2004; Bohac and McCall, 2008). The TVA reported water-use amounts similar to those reported by the USGS in this report. Total return flows for the Tennessee River watershed in Alabama were about 97 percent of total water withdrawn. Approximately 55 percent of public-supply water was returned to the environment through wastewater discharges in the Tennessee River watershed. About 96 percent of the water withdrawn by industrial water users was return flow. Thermoelectric water use in the Tennessee River watershed in Alabama was entirely used for once-through cooling, and almost 100 percent was returned to the environment.

Consumptive water use is the part of the water withdrawn that is evaporated, transpired, incorporated into crops, consumed by humans or livestock, or otherwise is removed from the immediate water environment (Hutson and others, 2009). In this report, consumptive use is referred to as net water demand and is determined from water withdrawal and return flow data at the county and subbasin levels for public supply, self-supplied industrial, and thermoelectric power (Hutson 
and others, 2004b). Total net water demand for the Tennessee River watershed in Alabama was about $136 \mathrm{Mgal} / \mathrm{d}$ (table 3). The total net demands by hydrologic unit (table 4) are lower than the county estimates of net water demand because they do not include residential water withdrawals. Net demands by category in order from largest to smallest were public supply ( $82 \mathrm{Mgal} / \mathrm{d}$; table 11), irrigation (22 Mgal/d; table 14), industrial (9 Mgal/d; table 18), livestock (7 Mgal/d; table 16), thermoelectric (5 Mgal/d; table 22), and mining (3 Mgal/d; table 20).

According to these summary data, the Tennessee River watershed in Alabama has large amounts of water available for multiple uses. Net demand for consumptive uses totaled less than 1 percent of total water available in 2005. Groundwater is not uniformly distributed across the watershed because of variations in geology and the dimensions of water-bearing rock units, and surface water is geographically limited to streams. Consequently, as noted by the USGS and GSA, not all of the existing water may be easily accessible for consumptive uses. In addition, demand requirements for navigation, recreation, ecological needs, and other uses may compete with increased consumptive uses in the watershed. As water managers plan for future water demands, additional data are needed about (1) the extent and accessibility of groundwater available for withdrawal, (2) the amount of return flows for categories such as self-supplied residential, livestock, and irrigation, and (3) projections of future population and industrial growth.

\section{Summary}

Water use, availability, and net water demand data for 2005 were summarized by the U.S. Geological Survey, in cooperation with the Alabama Department of Economic and Community Affairs, Office of Water Resources, for the Alabama portion of the Tennessee River watershed. State managers have identified the Tennessee River watershed within Alabama as a high-priority area for future water use planning for the State of Alabama because the watershed has high water withdrawal rates, some of the Alabama's large population centers, thermoelectric power generation, and industry, and a Federal interest in the flow of the river.
Total water use for the study area was 5,197 million gallons per day $(\mathrm{Mgal} / \mathrm{d})$. Surface water accounted for 99 percent, or $5,139 \mathrm{Mgal} / \mathrm{d}$, of the water used, while only about $58 \mathrm{Mgal} / \mathrm{d}$ of groundwater was used in the study area.

Water use was summarized by categories of water use and by county and 8-digit hydrologic subbasin. County-level estimates of water use were made for public-supply, selfsupplied residential, industrial, mining, livestock, irrigation, and thermoelectric water use categories. Hydrologic unit estimates of water use were made for all of the same categories except self-supplied residential. The greatest uses of water in the region were thermoelectric power generation $(4,762$ million gallons per day [Mgal/d], 92 percent of total use), followed by self-supplied industrial (214 Mgal/d, 4 percent of total use) and public supply (181 Mgal/d, 4 percent of total use). The counties and subbasins where thermoelectric power generation takes place (Limestone, Jackson, and Colbert Counties; subbasins 06030001, 06030002, and 06030005) had the greatest withdrawals and use. When thermoelectric power generation was not considered, Morgan, Madison, Colbert, and Lawrence Counties and subbasin 06030002 had the greatest withdrawals.

Water availability estimates and information compiled by the Geological Survey of Alabama (GSA) and the Tennessee Valley Authority (TVA) were summarized. The GSA estimated that the total water availability in the Tennessee River watershed within Alabama is $34,567 \mathrm{Mgal} / \mathrm{d}$ (1,967 Mgal/d of groundwater, $8,200 \mathrm{Mgal} / \mathrm{d}$ of surface water from the Tennessee River watershed within the State of Alabama, and $24,400 \mathrm{Mgal} / \mathrm{d}$ inflow of the Tennessee River to Alabama). The TVA reported that about 97 percent of total water withdrawn was returned to the environment, and the resulting net demand (136 Mgal/d) accounted for less than 1 percent of estimated available water. These data indicate that the Tennessee River watershed in Alabama has large amounts of water available for multiple uses. As noted by the USGS and GSA, however, not all of the existing water may be easily accessible. Additional data are needed about (1) the extent and accessibility of groundwater available for withdrawal, (2) the amount of return flows for water-use categories such as self-supplied residential, livestock, and irrigation, and (3) projections of future population and industrial growth, to improve future water demand estimations and regional water-use planning. 


\section{References}

Alabama Department of Conservation and Natural Resources, 2008, Tennessee River-Fish and fishing in the Alabama portion of the Tennessee River, accessed November 1, 2011, at http://www.dcnr.state.al.us/fishing/freshwater/where/ rivers/tennessee/.

Alabama Development Office, 2004, Alabama industrial directory, 2003-2004: Montgomery, Alabama, 557 p.

Baker, R.M., 1989, Water availability in Jackson County, Alabama: Geological Survey of Alabama Special Map 209, 84 p., 2 pls.

Baker, R.M., and Moser, P.H., 1989, Water availability in DeKalb County, Alabama: Geological Survey of Alabama Special Map 215, 71 p., 2 pls.

Bohac, C.E., and Koroa, M.C., 2004, Tennessee Valley water supply inventory and needs analysis: Tennessee Valley Authority [variously paged].

Bohac, C.E., and McCall, M.J., 2008, Water use in the Tennessee Valley for 2005 and projected use in 2030: Tennessee Valley Authority [variously paged].

Bossong, C.R., 1989, Geohydrology and susceptibility of major aquifers to surface contamination in Alabama; Area 2: U.S. Geological Survey Water-Resources Investigations Report 88-4177, 22 p.

Bossong, C.R., and Harris, W.F., 1987, Geohydrology and susceptibility of major aquifers to surface contamination in Alabama; Area 1: U.S. Geological Survey Water-Resources Investigations Report 87-4068, 34 p.

Cook, M.R., Moss, N.E., and Jennings, S.P., 2009, Groundwater hydrogeology, recharge, and water availability in the Tennessee River watershed of Alabama: Geological Survey of Alabama Open-File Report 0910, 44 p.

Energy Information Administration, 2008, EIA-767 data files, annual steam-electric plant operation and design data, accessed November 6, 2008, at http://www.eia.doe.gov/ cneaflelectricity/page/eia767.html.

Energy Information Administration, 2009a, Form EIA-906 and EIA-920 databases, accessed January 27, 2009, at http://www.eia.doe.gov/cneaf/electricity/page/eia906_920. html.

Energy Information Administration, 2009b, Electric power annual 2007-Data tables, accessed January 27, 2009, at http://www.eia.doe.gov/cneaf/electricity/epa/ epa sprdshts.html.
Hunter, J.A., 1991, Ground water availability in Limestone County, Alabama: Geological Survey of Alabama Special Map 226, 60 p., 2 pls.

Hutson, S.S., Barber, N.L., Kenny, J.F., Linsey, K.S., Lumia, D.S., and Maupin, M.A., 2004a, Estimated use of water in the United States in 2000: U.S. Geological Survey Circular $1268,46 \mathrm{p}$.

Hutson, S.S., Koroa, M.C., and Murphree, C.M., 2004b, Estimated use of water in the Tennessee River watershed in 2000 and projections of water use to 2030: U.S. Geological Survey Water-Resources Investigations Report 03-4302, $89 \mathrm{p}$.

Hutson, S.S., Littlepage, T.M., Harper, M.J., and Tinney J.O., 2009, Estimated use of water in Alabama in 2005: U.S. Geological Survey Scientific Investigations Report 2009-5163, 210 p.

Kammerer, J.C., 1976, Water quantity requirements for public supplies and other uses, in Gehm, H.W., and Bregman, J.I., Handbook of water resources and pollution control: New York, N.Y., Van Nostrand Reinhold Co., p. 44-83.

MacKichan, K.A., 1951, Estimated water use in the United States, 1950: U.S. Geological Survey Circular 115, 13 p.

MacKichan, K.A., 1957, Estimated water use in the United States, 1955: U.S. Geological Survey Circular 398, 18 p.

MacKichan, K.A., and Kammerer, J.C., 1961, Estimated water use in the United States, 1960: U.S. Geological Survey Circular 456, 26 p.

Miller, J.A., 1990, Groundwater atlas of the United StatesAlabama, Florida, Georgia, and South Carolina: U.S. Geological Survey Hydrologic Atlas 730-G, accessed October 5, 2012, at http://pubs.usgs.gov/ha/ha730/ch_g/index.html.

Mooty, W.S., and Richardson, J.R., 1998, Water use in Alabama, 1995: U.S. Geological Survey Water-Resources Investigations Report 98-4154, 92 p.

Murray, C.R., 1968, Estimated water use in the United States, 1965: U.S. Geological Survey Circular 556, 53 p.

Murray, C.R., and Reeves, E.B., 1972, Estimated water use in the United States, 1970: U.S. Geological Survey Circular $676,37 \mathrm{p}$.

Murray, C.R., and Reeves, E.B., 1977, Estimated water use in the United States, 1975: U.S. Geological Survey Circular $765,37 \mathrm{p}$.

National Oceanic and Atmospheric Administration, 2009, Monthly station normals, accessed January 5, 2011, at http://cdo.ncdc.noaa.gov/cgi-bin/climatenormals/ climatenormals.pl. 
Solley, W.B., Chase, E.B., and Mann, W.B., IV, 1983, Estimated water use in the United States, 1980:

U.S. Geological Survey Circular 1001, 56 p.

Solley, W.B., Merk, C.F., and Pierce, R.R., 1988, Estimated water use in the United States, 1985: U.S. Geological Survey Circular 1004, 82 p.

Solley, W.B., Pierce, R.R., and Perlman, H.A., 1993, Estimated water use in the United States, 1990: U.S. Geological Survey Circular 1081, $71 \mathrm{p}$.

Solley, W.B., Pierce, R.R., and Perlman, H.A., 1998, Estimated use of water in the United States in 1995: U.S. Geological Survey Circular 1200, $71 \mathrm{p}$.

Tennessee Valley Authority, 2012, River management, accessed October 9, 2012, at http://www.tva.com/river/ index.htm.

TheGolfCourses.net, 2009, Golf courses in Alabama, accessed January 4, 2013, at http://www.thegolfcourses.net/golfcourses/AL/Alabama.htm.

The University of Alabama, Center for Business and Economic Research, 2011, Alabama county population 20002010 and projections 2015-2035 (Interim Series), accessed June 21, 2012, at http://cber.cba.ua.edu/edata/est_prj.html.

U.S. Census Bureau, 1992, 1990 Census of population and housing, summary of social, economic, and housing characteristics-Alabama: Washington, D.C., U.S. Department of Commerce report 1990 CPH-5-2, 218 p., Appendixes A-F, accessed September 12, 2007, at http://www.census.gov/ prod/cen1990/cph5/cph-5-2.pdf.

U.S. Census Bureau, 2006a, Annual estimates of the population for counties, April 1, 2000 to July 1, 2005 (Alabama), accessed March 21, 2006, at http://www.census.gov/popest/ counties/CO-EST2005-01.html.

U.S. Census Bureau, 2006b, Cumulative estimates of population change for counties of Alabama and county rankings, April 1, 2000 to July 1, 2005, accessed September 23, 2010, at http://www.census.gov/popest/counties/CO-EST2005-02. html.

U.S. Census Bureau, Geography Division, 2001, Census 2000 TIGER/Line ${ }^{\circledR}$ Files, accessed September 21, 2010, at http:// www.census.gov/geo/www/tiger/tiger2k/tgr2000.html.
U.S. Department of Agriculture, 2004, Federal standards for delineation of hydrologic unit boundaries, version 2.0, October 1, 2004, accessed September 15, 2008, at ftp://ftp-fc.sc.egov.usda.gov/NCGC/products/watershed/ hu-standards.pdf.

U.S. Department of Agriculture, Soil Conservation Service, 1993, State of Alabama hydrologic unit map with drainage areas by counties and sub-watershed, Appendixes A-F.

U.S. Department of Agriculture, National Agricultural Statistics Service, 2004a, 2002 Census of agriculture, Alabama, state and county data-Volume 1, Geographic area series, Part 1, AC-02-A-1, accessed September 12, 2007, at http://www.agcensus.usda.gov/Publications/2002/ Volume_1,_Chapter_1_State_Level/Alabama/index.asp.

U.S. Department of Agriculture, National Agricultural Statistics Service, 2004b, 2002 Census of agriculture, 2003 farm and ranch irrigation survey-Volume 3, Special studies, Part 1, AC-02-SS-1, 176 p., accessed September 12, 2007, at http://www.agcensus.usda.gov/Publications/2002/FRIS/ index.asp.

U.S. Department of Agriculture, National Agricultural Statistics Service, 2006a, Alabama Agricultural Statistics: Bulletin 48, $96 \mathrm{p}$.

U.S. Department of Agriculture, National Agricultural Statistics Service, 2006b, U.S. poultry-Production and value, 2005 summary, $10 \mathrm{p}$.

U.S. Environmental Protection Agency, 2009, Safe drinking water query form for the State of Alabama, accessed January 27, 2009, at http://oaspub.epa.gov/enviro/sdw_form _ $v 2$.create_page?state_abbr $=A L /$.

U.S. Geological Survey, 2007a, Facing tomorrow's challenges-U.S. Geological Survey science in the decade 2007-2017: U.S. Geological Survey Circular 1309, 67 p.

U.S. Geological Survey, 2007b, Boundary descriptions and names of regions, subregions, accounting units and cataloging units (Region 03), accessed November 26, 2008, at http://water.usgs.gov/GIS/huc_name.html\#Region03.

U.S. Geological Survey, 2012, WaterWatch, accessed September 25, 2012, at http://waterwatch.usgs.gov. 



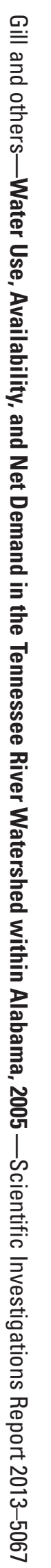

